\title{
NITROGÊNIO E METAIS PESADOS EM LATOSSOLO E EUCALIPTO CINQÜENTA E CINCO MESES APÓS A APLICAÇÃO DE BIOSSÓLIDO
}

\author{
MARTA VELASCO MOLINA
}

Dissertação apresentada à Escola Superior de Agricultura "Luiz de Queiroz", Universidade de São Paulo, para a obtenção do título de Mestre em Agronomia, Área de Concentração: Solos e Nutrição de Plantas.

PIRACICABA

Estado de São Paulo - Brasil

Julho - 2004 


\title{
NITROGÊNIO E METAIS PESADOS EM LATOSSOLO E EUCALIPTO CINQÜENTA E CINCO MESES APÓS A APLICAÇÃO DE BIOSSÓLIDO
}

\author{
MARTA VELASCO MOLINA
}

Licenciada em Ciências Ambientais

ORIENTADORA: Prof. ${ }^{a}$.Dra ${ }^{a}$.MARÍA EMÍLIA MATTIAZZO-PREZOTTO

Dissertação apresentada à Escola Superior de Agricultura "Luiz de Queiroz", Universidade de São Paulo, para a obtenção do título de Mestre em Agronomia, Área de Concentração: Solos e Nutrição de Plantas.

PIRACICAB A

Estado de São Paulo - Brasil

Julho - 2004 


\section{Dados Internacionais de Catalogação na Publicação (CIP)}

DIVISÃO DE BIBLIOTECA E DOCUMENTAÇÃO - ESALQ/USP

Velasco Molina, Marta

Nitrogênio e metais pesados em latossolo e eucalipto cinqüenta e cinco meses após a aplicação de biossólido.

$66 \mathrm{p}$.

Dissertação (mestrado) - - Escola Superior de Agricultura Luiz de Queiroz, 2004.

Bibliografia.

1. Eucalipto 2. Fertilidade do solo 3. Lodo de esgoto 4. Metal pesado do solo 5. Nitrogênio I. Título

CDD 634.9734

"Permitida a cópia total ou parcial deste documento, desde que citada a fonte - O autor" 
Tristes guerras

si no es el amor la empresa, Tristes, tristes.

M.H.

Que um país seja pequeno

e de escassa população

que importa!

deixemos seus habitantes viver em paz

e cultivar seu torrão de terra!

deixemo-los viver em paz!

envelhecer contentes

morrer tranqüilos...

mas não os privemos da sua liberdade.

L.S. 


\section{Para mi familia}

el fruto de una nueva ausencia, con todo el amor que no se perdió en el camino.

Ao riso de luz de Bruna 


\section{AGRADEÇO} lingüísticas, en especial Paula, Suzana, Aline, Valdomiro, Jack, Miriam, Felipe, Tiago, Jordi, Rodella, Adriana, Barizon, Jonas, Lúcia, Fabiana, 51, Limão, Estevão...

$\infty$ A Angélica, Ana, Nancy, Flávia, Armelinda y demás funcionari@s, que poco a poco simplificaron dificultades y facilitaron mi paso por esta etapa.

$\infty$ A Héctor, Silvia y resto de "gringolandia", por compartir más que un idioma.

$\infty$ A Celia y Lalín, que al "cruzar el charco" hicieron que aquí y allí siga siendo relativo.

$\infty$ A Vânia, Lilian, Michelle y Ju, por su hospitalidad para comenzar en este lado. A Lyssa y Liana, por los inicios.

$\infty$ A Vera y estagiários del centro de fisioterapia da ESALQ, por cuidar de mis "rotos".

$\infty$ A la tecnología que, llevándome allá donde las voces se apagan y los brazos se extinguen, creaba fuerzas para compartir con los que siento respirar.

$\infty$ A aquellos que, aún sin estar en estas líneas, estuvieron. 


\section{SUMÁRIO}

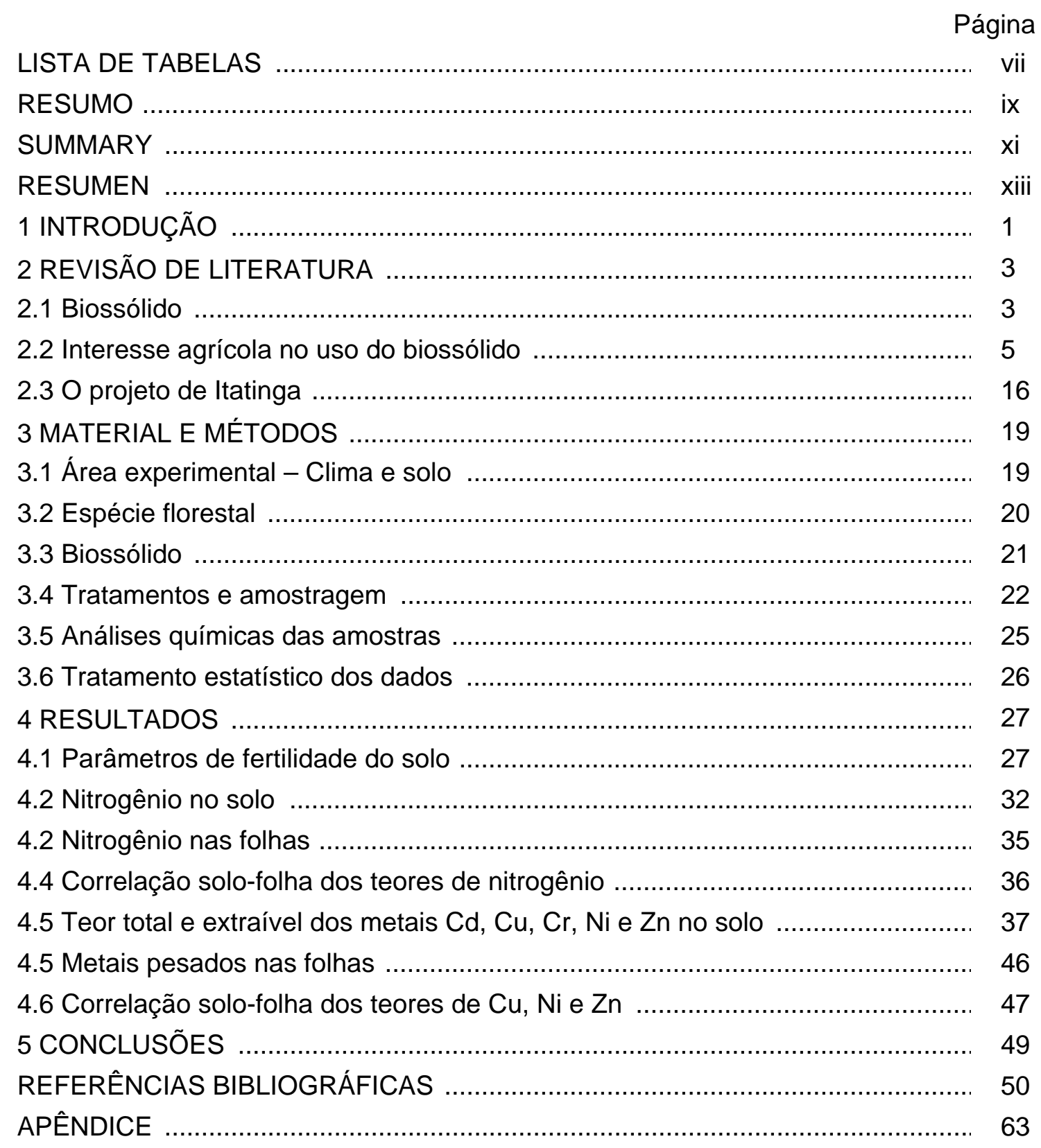




\section{LISTA DE TABELAS}

Página

1 Concentrações máximas ( $\mathrm{mg} \mathrm{kg}^{-1}$ base seca) permissíveis de metais em biossólido para uso agroflorestal ............................................................ 5

2 Características químicas do solo utilizado no experimento ................................ 20

3 Granulometria e teores totais de óxidos de ferro, alumínio e silício

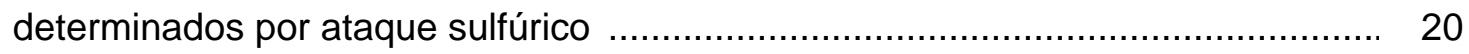

4 Algumas características do biossólido utilizado .............................................. 21

5 Adição inicial de nutrientes e metais pesados $\left(\mathrm{kg} \mathrm{ha}^{-1}\right)$, via adubação mineral ou biossólido, aos tratamentos do experimento

6 Parâmetros de fertilidade do solo dos tratamentos nas profundidades estudadas

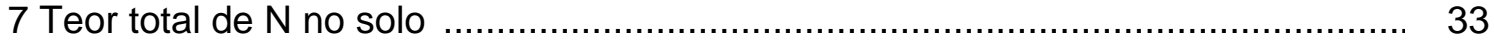

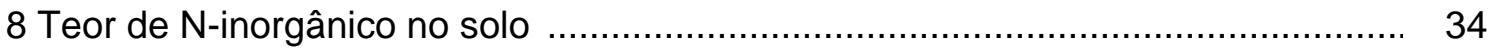

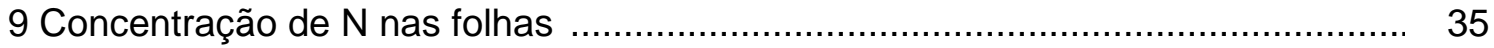

10 Coeficiente de correlação entre concentração foliar de $\mathrm{N}$ e teor total e inorgânico de $\mathrm{N}$ no solo

11 Teor total de Cr no solo

12 Teor total de Cu no solo 39

13 Teor de Cu-extraível no solo 40

14 Teor total de Ni no solo 41

15 Teor de Ni-extraível no solo 42

16 Teor total de $\mathrm{Zn}$ no solo 43

17 Teor de Zn-extraível no solo 44

18 Concentração de metais nas folhas

19 Coeficiente de correlação entre concentração foliar e teor total de Cu, Ni e Zn no solo

20 Coeficiente de correlação entre concentração foliar e teor extraível (Mehlich 3) de $\mathrm{Cu}$, Ni e Zn no solo 
Apêndice 1 - Valor pH dos tratamentos..................................................... 64

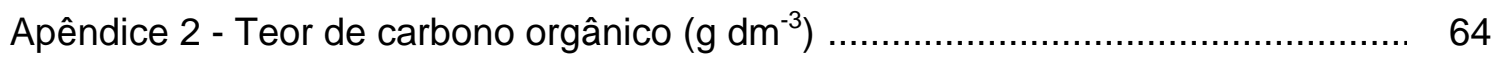

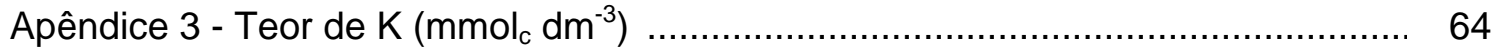

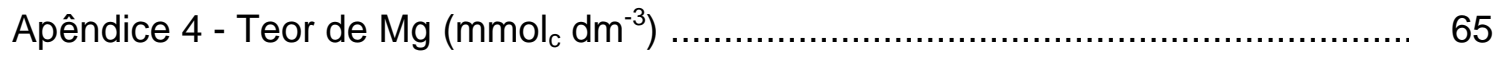

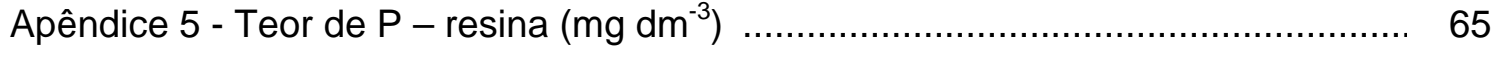

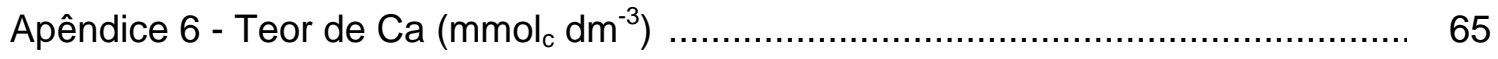

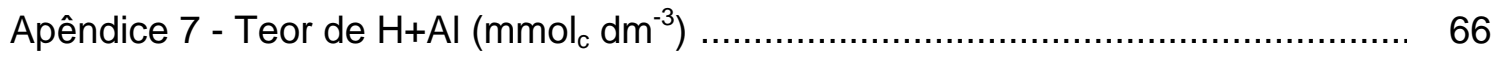

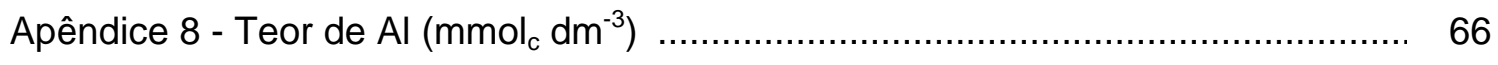

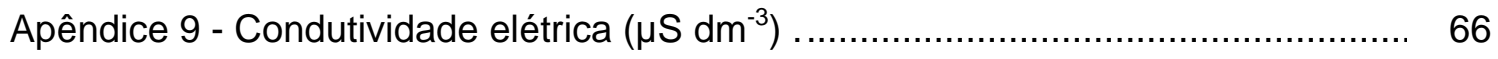




\title{
NITROGÊNIO E METAIS PESADOS EM LATOSSOLO E EUCALIPTO CINQÜENTA E CINCO MESES APÓS A APLICAÇÃO DE BIOSSÓLIDO
}

\author{
Autora: MARTA VELASCO MOLINA \\ Orientadora: Profa. Dra. MARIA EMILIA MATTIAZZO-PREZOTTO
}

\section{RESUMO}

As preocupações com o ambiente e com a saúde da população exigem que a cada dia uma maior porcentagem de esgotos sanitários sejam tratados. Entretanto esse tratamento é responsável por um novo problema: as quantidades de lodo geradas. Uma das alternativas para destino final desse resíduo, que após devidamente higienizado e condicionado passa a ser conhecido como biossólido, é o seu uso racional no solo com culturas que não são destinadas a consumo direto como é o caso dos plantios florestais. Nesse aspecto, são necessários estudos procurando avaliar em longo prazo, os efeitos benéficos do biossólido no fornecimento de nutrientes e também os prováveis prejuízos causados pela presença de metais pesados.

No presente estudo é feita a avaliação dos parâmetros de fertilidade de Latossolo Vermelho-Amarelo Distrófico típico, A moderado, textura média, em várias profundidades $(0-10,10-20,20-30,30-60$ e 60-90 cm) e dos teores de $\mathrm{N}$ e dos metais $\mathrm{Cd}, \mathrm{Cr}, \mathrm{Cu}$, Ni e Zn no solo e em folhas de Eucalyptus grandis, numa área onde, há cinqüenta e cinco meses, foi feita a aplicação de biossólido em doses de 10, 20 e $40 \mathrm{t} \mathrm{ha}^{-1}$. O ensaio foi montado em 1998 seguindo um delineamento com 6 tratamentos dispostos em quatro blocos aleatorizados totalizando 24 parcelas experimentais. 
Os resultados obtidos, 55 meses após a aplicação do biossólido, permitiram as seguintes conclusões:

1. embora a aplicação de biossólido em quantidades superiores a $20 \mathrm{t} \mathrm{ha}^{-1}$ tenha resultado em aumento dos teores de $\mathrm{N}$-total em profundidade no solo, este incremento não supõe riscos ambientais diferentes dos decorrentes da fertilização mineral;

2. a concentração foliar de nitrogênio não foi influenciada pelo aporte de nitrogênio do biossólido;

3. as doses utilizadas de biossólido não proporcionaram aumentos nos teores dos metais $\mathrm{Cd}$ e $\mathrm{Cr}$ no solo e não foram verificadas evidências de fitodisponibilidade desses metais;

4. os teores de $\mathrm{Cu}$, Ni e Zn extraíveis aumentaram com o tempo decorrido desde a aplicação do biossólido, indicando a possibilidade de mobilidade e fitodisponibilidade desses metais no solo quando da aplicação do biossólido na dose de $40 \mathrm{t} \mathrm{ha-1}$ (base seca). Não obstante, estes aumentos não representaram risco para a cultura do eucalipto. 


\title{
NITROGEN AND HEAVY METALS IN THE SOIL AND IN EUCALYPTUS GRANDIS LEAVES 55 MONTHS AFTER BIOSOLID APPLICATION
}

\author{
Author: MARTA VELASCO MOLINA \\ Advisor: Profa . Dra. MARIA EMILIA MATTIAZZO-PREZOTTO
}

\section{SUMMARY}

Concern regarding environmental quality and human health demands wastewater treatment technology and, with this treatment, sewage sludge is generated. The sewage sludge, after a properly microorganism reduction and physically conditioning, is usually known as biosolid. One of the alternatives for biosolid final disposal is the application in agriculture in areas with cultures not used for food consumption such as planted forestry. In this case it is necessary to evaluate, in long term studies, on the efficiency of the biosolid as a nutrient source supply as well as the possible harm effects considering the heavy metals content in the waste. In this study, an evaluation on $\mathrm{N}$ and $\mathrm{Cd}, \mathrm{Cr}, \mathrm{Cu}, \mathrm{Ni}$ and $\mathrm{Zn}$ in soil (Typic Haplorthox) and in Eucalyptus grandis leaves, was effected in an experimental area where biosolid was applied in levels of 10,20 and $40 \mathrm{t} \mathrm{ha}^{-1}, 55$ months ago. The experimental design adopted was randomized blocks, for treatments and replications. 
The results obtained, after 55 months of biosolid application, were:

1. there was an increase on nitrogen level in the deepest soil layer that was evaluated $(60-90 \mathrm{~cm})$ due to biosolid application in levels of 20 or $40 \mathrm{t} \mathrm{ha}^{-1}$, but the environmental risk of this increase is not different from the one that is caused by the use of mineral fertilizers;

2. the nitrogen level in Eucalyptus grandis leaves was not affected by biosolid application;

3. levels of $\mathrm{Cd}$ and $\mathrm{Cr}$ did not increase in the soil and no availability of those metals to the trees was observed;

4. there was an increase, over time, in the soil level of $\mathrm{Cu}, \mathrm{Ni}$ and $\mathrm{Zn}$ removed by Mehlich extractant, in the treatment using $40 \mathrm{t} \mathrm{ha}^{-1}$ of biosolids. These increases indicate the possibility of mobility and plant availability of those metals, although these increases did not represent any harm effects to Eucalyptus grandis trees. 


\title{
NITRÓGENO Y METALES PESADOS EN LATOSSOLO Y EUCALIPTO CINCUENTA Y CINCO MESES DESPUÉS DE APLICAR BIOSÓLIDO
}

\author{
Autora: MARTA VELASCO MOLINA \\ Tutora: Profa. Dra. MARIA EMILIA MATTIAZZO-PREZOTTO
}

\section{RESUMEN}

Las preocupaciones ambientales y de salud pública exigen cada día más que las aguas residuales sean debidamente tratadas. Al mismo tiempo, este tratamiento es responsable de un nuevo problema: las elevadas cantidades de lodo de depuradora generadas. Una de las alternativas como destino final de este subproducto, que después de recibir tratamiento de higienización y acondicionamiento es conocido como biosólido, es el uso racional en cultivos que no sean de consumo directo, como es el caso de las plantaciones forestales. En este ámbito, son necesarios estudios que evalúen, a largo plazo, los efectos benéficos del biosólido como suministrador de nutrientes y, también, los probables perjuicios derivados de la presencia de metales pesados en este material.

En el presente estudio fue realizada la evaluación de los contenidos de $\mathrm{N}$ y de los metales $\mathrm{Cd}, \mathrm{Cr}, \mathrm{Cu}, \mathrm{Ni}$ y $\mathrm{Zn}$ en el suelo (Typic Haplorthox), en varias profundidades (0-10, 10-20, 20-30, 30-60 y 60-90 cm) y en las hojas de Eucalyptus grandis, cincuenta y cinco meses después de la aplicación de biosólido en dosis de 10, 20 y $40 \mathrm{t} \mathrm{ha}^{-1}$. 
Este ensayo fue instalado en 1998, con un total de 6 tratamientos distribuidos en 4 bloques al azar, resultando en 24 parcelas experimentales.

Los resultados obtenidos 55 meses después de la aplicación del biosólido han permitido establecer las siguientes conclusiones:

1. aunque la aplicación de biosólido en cantidades superiores a $20 \mathrm{t} \mathrm{ha}^{-1}$ provocó un aumento de los contenidos de N-total en la profundidad del suelo, este incremento no supuso riesgos ambientales diferentes de los derivados de la utilización de fertilizantes minerales;

2. la concentración foliar de nitrógeno no fue influenciada por el aporte de nitrógeno del biosólido;

3. las dosis utilizadas de biosólido no proporcionaron aumento en los contenidos de $\mathrm{Cd}$ y $\mathrm{Cr}$ en el suelo y no fueron observadas evidencias de fitodisponibilidad de esos metales;

4. los contenidos de $\mathrm{Cu}, \mathrm{Ni}$ y Zn extraíbles aumentaron con el tiempo transcurrido desde la aplicación del biosólido, lo cual indica la posible movilidad y fitodisponibilidad de estos metales en el suelo, cuando el biosólido fue aplicado en la dosis de $40 \mathrm{t} \mathrm{ha}^{-1}$ (base seca). No obstante, estos aumentos no representaron riesgo para el cultivo del eucalipto. 


\section{INTRODUÇÃO}

Numa sociedade em continuo crescimento, como a que vivemos, o ímpeto pela conservação do meio ambiente, necessidade de minimização dos resíduos produzidos pelas atividades antropogênicas e a rentabilização dos custos envolvidos nos processos de produção, são fatores que devem unir-se num único esforço. Com esta idéia vêm sendo desenvolvidas, desde a década de 70, múltiplas pesquisas visando a utilização do resíduo "lodo de esgoto". Este resíduo é proveniente de estações de tratamento de esgotos sanitários (ETE) e, após ser submetido a processos de redução adicional dos patógenos presentes e melhoria de suas características físicas, é usualmente referido como biossólido.

Diferentes são os destinos finais propostos para esse biossólido, sendo que o uso agroflorestal posiciona-se como uma das alternativas mais atraentes, tendo em vista a reciclagem dos nutrientes nele contidos, aliada a benefícios atribuídos ao material orgânico também presente no biossólido. Entretanto, não se pode esquecer que biossólidos provem da concentração dos sólidos presentes no esgoto sanitário e que com a aplicação desse material no solo agrícola elementos ou compostos indesejáveis (por exemplo, metais pesados, compostos orgânicos recalcitrantes) são introduzidos, podendo causar poluição.

Dado que cada biossólido possui características particulares e que cada sistema reage de forma diferente quando Ihe são introduzidos novos fatores não é aceitável extrapolação dos resultados da aplicação de biossólido de uma cultura para outra. No entanto, os resultados obtidos de experiências anteriores podem servir, até certo ponto, de orientadores no estabelecimento de novas plantações. 
O objetivo principal deste estudo é avaliar, no solo e na planta, os teores de nitrogênio e metais pesados, cinqüenta e cinco meses após aplicação de biossólido num Latossolo Vermelho-Amarelo Distrófico típico, A moderado, textura média, cultivado com Eucalyptus grandis. Especificamente serão determinados, em relação às diferentes doses de biossólido aplicadas:

- teor de nitrogênio total e de nitrogênio inorgânico (nítrico+amoniacal) e teor total dos metais pesados $\mathrm{Cd}, \mathrm{Cr}, \mathrm{Cu}, \mathrm{Ni}$ e $\mathrm{Zn}$ no solo, em diferentes profundidades ao longo do perfil;

- concentração de nitrogênio e concentração dos metais pesados $\mathrm{Cd}, \mathrm{Cr}, \mathrm{Cu}, \mathrm{Ni}$ e Zn nas folhas do eucalipto;

- fitodisponibilidade dos metais pesados $\mathrm{Cd}, \mathrm{Cr}, \mathrm{Cu}, \mathrm{Ni}$ e $\mathrm{Zn}$ avaliada pela solução extratora Mehlich 3;

- parâmetros de avaliação da fertilidade do solo nas diferentes profundidades do perfil.

As hipóteses de partida deste estudo foram:

- a adição de biossólido em doses de até $40 \mathrm{t} \mathrm{ha}^{-1}$, base seca, não promove a acumulação de nitrogênio e dos metais $\mathrm{Cd}, \mathrm{Cr}, \mathrm{Cu}$, Ni e $\mathrm{Zn}$, ao longo do perfil, em médio prazo;

- N, Cu, Ni e Zn provenientes do biossólido, aplicado em doses de até $40 \mathrm{t} \mathrm{ha}^{-1}$, base seca, apresentam fitodisponibilidade;

- Cd e Cr provenientes do biossólido, aplicado em doses de até $40 \mathrm{t} \mathrm{ha}^{-1}$, base seca, não apresentam evidências de fitodisponibilidade. 


\section{REVISÃO DE LITERATURA}

\subsection{Biossólido}

As águas residuárias têm origens diversas: atividade industrial, uso doméstico, precipitações e infiltrações não controladas. Águas residuárias constituídas predominantemente de esgoto doméstico são usualmente denominadas esgoto sanitário.

O esgoto sanitário é recolhido por redes coletoras e conduzidas até as Estações de Tratamentos de Esgoto (ETEs) onde vai receber tratamento que é função de suas características e das condições técnicas da ETE. O processo de tratamento dos esgotos tem como produtos finais: um efluente apto para reuso ou para ser descartado nos sistemas aquáticos e um resíduo semi-sólido chamado lodo de esgoto.

Uma vez que tanto a matéria prima quanto o processo de obtenção do lodo de esgoto são próprios de cada ETE, o lodo resultante é um material heterogêneo contendo, em quantidades variáveis, água, nutrientes, matéria orgânica, microrganismos e metais pesados.

Segundo Tsutya (2000) podem-se distinguir três tipos de lodos oriundos do tratamento de esgotos sanitários:

- lodo primário: lodo bruto produzido nos decantadores primários, com coloração acinzentada, aspeto pegajoso e odor ofensivo;

- lodo ativado: produzido nos reatores biológicos, com aparência floculenta, coloração marrom e odor pouco ofensivo se mantido em condições aeróbias;

- lodo digerido: o que passou por processo de estabilização biológica, sem odor ofensivo.

Em adição ao tratamento biológico, o lodo pode ser submetido a desidratação, estabilização, condicionamento e secagem que tem por objetivo a redução da massa de lodo produzido, controle de odor e redução de organismos patogênicos. 
Diferentes são os destinos que estão sendo estudados para o lodo de esgoto uma vez que o custo da disposição desse material pode corresponder a até $60 \%$ dos custos de operação de uma estação de tratamento no caso da opção pela disposição em aterros sanitários (Centro Nacional de Referência e Gestão Ambiental Urbana, 2001).

Quando o lodo é resultante de sistema de tratamento biológico de despejos sanitários e condicionado de forma a apresentar características tais que permitem a sua utilização com segurança na agricultura, então passa a ser conhecido como "biossólido". A Agência de Proteção Ambiental dos Estados Unidos (USEPA/EUA), através da sua regulamentação (EPA, Part 503, 1995), define biossólido como um produto sólido orgânico produzido por processos de tratamento dos esgotos municipais. No Estado de São Paulo a aplicação desse resíduo no solo deve obedecer aos critérios estabelecidos pela norma elaborada pela Companhia de Tecnologia de Saneamento Ambiental do Estado de São Paulo (P4.230, CETESB, 1999) que foi elaborada a partir da norma americana (EPA, Part 503, 1995). Nessa norma são estabelecidos os critérios para o uso de biossólido em áreas agrícolas, áreas florestais, de produção ou de revegetação, e áreas degradadas, visando o atendimento de exigências ambientais. A Norma também estabelece as concentrações máximas permitidas para elementos patogênicos e poluentes químicos, além de exigir redução da capacidade de atração de vetores, como moscas e roedores.

A densidade de patógenos presentes em biossólidos é estimada através da determinação da quantidade de coliformes fecais. Assim sendo, a Norma P4.230 (CETESB, 1999) classifica os biossólidos em classe A ou classe B segundo número mais provável (NMP) de coliformes fecais existentes em 1 grama de sólidos totais (ST):

- Biossólido Classe A: aquele que apresenta quantidade de coliformes fecais menor que $1000 \mathrm{NMP} \mathrm{gST}^{-1}$. O biossólido classe A pode ser utilizado sem restrições;

- Biossólido Classe B: aquele que apresenta uma quantidade de coliformes fecais inferior a 2.000.000 NMP gST ${ }^{-1}$. Esse tipo de biossólido é de uso mais restrito, devendo ser aplicado em grandes culturas, reflorestamento e outras situações onde o risco pode ser mais controlado. O uso desse tipo de biossólido em áreas agrícolas ou florestais exige projeto para aplicação e acompanhamento de engenheiro agrônomo ou florestal responsável.

Biossólidos com teor de coliformes fecais superior a $2.10^{6} \mathrm{NMP}_{\mathrm{gST}}{ }^{-1}$ não podem ser utilizados no solo agrícola. 
Outro fator que pode restringir o uso de biossólidos em áreas agrícolas e florestais é a quantidade de metais pesados presentes. Nesse caso a Norma P4.230 (CETESB, 1999) apresenta os valores constantes da Tabela 1. Nessa tabela também são apresentados os limites de metais permitidos em biossólidos pela União Européia e Canadá (Tsutiya, 1999). A diferença entre os valores apresentados nessa tabela é função do critério adotado na sua definição: enquanto que a norma americana, na qual a norma paulista foi baseada, tem como critério a denominada avaliação de risco, a norma da União Européia e do Canadá utilizaram o conceito de não degradação do solo e do meio ambiente.

Tabela 1 Concentrações máximas ( $\mathrm{mg} \mathrm{kg}^{-1}$ base seca) permissíveis de metais em biossólido para uso agroflorestal

\begin{tabular}{ccccccccccc}
\hline Área & $\mathrm{As}$ & $\mathrm{Cd}$ & $\mathrm{Cr}$ & $\mathrm{Cu}$ & $\mathrm{Hg}$ & $\mathrm{Mo}$ & $\mathrm{Ni}$ & $\mathrm{Pb}$ & $\mathrm{Se}$ & $\mathrm{Zn}$ \\
\hline U.E. & - & $20 / 40$ & - & $1000 / 1750$ & $16 / 25$ & - & $300 / 400$ & $750 / 1200$ & - & $2500 / 4000$ \\
Canadá & 75 & 20 & - & - & 5 & 20 & 180 & 500 & 14 & 1850 \\
São Paulo & 75 & 85 & - & 4300 & 57 & 75 & 420 & 840 & 100 & 7500 \\
\hline
\end{tabular}

\subsection{Interesse agrícola no uso do biossólido}

Grande parte das áreas florestais no Brasil está localizada em solos de baixa fertilidade, degradados ou em processo de degradação. Muitos desses processos são, de alguma forma, provocados pela própria atividade florestal. O aumento da mecanização e o uso prolongado de fertilizantes minerais (fontes de nitrogênio, fósforo e potássio) são os principais indutores de resultados indesejáveis para o ambiente, como compactação do solo, contaminação de águas subterrâneas e perda de outros nutrientes via exportação pelo aumento produção (Harrison et al., 1996).

O uso de resíduos orgânicos em povoamentos de eucaliptos já vem sendo praticado por diferentes empresas florestais do Brasil visando minimizar os aspetos negativos do manejo intensivo das florestas plantadas, melhorando a produtividade e diminuindo os custos de aplicação de fertilizantes químicos (Santos \& Tsutya, 1997; Moro, 1994; Zen et al., 1994). Segundo Poggiani \& Benedetti (2000) uma grande vantagem da aplicação do biossólido em plantações florestais consiste no fato de que os principais produtos destas culturas não se destinam à alimentação humana ou 
animal, possibilitando uma maior segurança quanto à dispersão de eventuais contaminações.

O teor de nutrientes presentes é um dos principais atrativos do uso do biossólido no solo havendo na literatura vários estudos que demonstram a eficiência do biossólido no fornecimento de $\mathrm{N}, \mathrm{P}, \mathrm{Ca}, \mathrm{S}$ e $\mathrm{Zn}$ para várias espécies vegetais. Dentre esses trabalhos podem ser citados os de Silva et al. (1998), Marques (1997), Berton et al. $(1997,1989)$ e Carvalho \& Barral (1981).

\subsubsection{Nitrogênio}

No que se refere ao nitrogênio, ele se apresenta no biossólido predominantemente sob forma orgânica podendo ser encontrados teores variáveis de nitrogênio amoniacal (de 5 a 60\% do total) em função do processo gerador do resíduo (Tsutya, 2001).

Uma vez adicionado ao solo, o nitrogênio presente sob forma orgânica é passível de reações de mineralização e, sendo as condições do meio aeróbias e oxidantes, há formação de nitratos, que são as formas de nitrogênio mais facilmente perdidas por lixiviação. Outros processos pelos quais existe perda de nitrogênio são a fixação e erosão. Perdas de $\mathrm{N}$ no solo por volatilização da amônia não tem sido observada mesmo em condições alcalinas do meio (Andrade \& Mattiazzo, 1999).

As quantidades de nitrogênio que podem ser perdidas por lixiviação após a aplicação de biossólidos têm sido avaliadas por diversos autores. Oliveira (1995), num ensaio em colunas de lixiviação com doses crescentes de biossólido incorporado na camada de $0-20 \mathrm{~cm}$ do solo, encontrou perdas de até $47,5 \%$ do $\mathrm{N}$ adicionado via biossólido em solo arenoso. Ainda nesse trabalho o autor verificou que as quantidades de $\mathrm{N}^{-\mathrm{NO}_{3}}{ }^{-}$lixiviadas não se apresentaram proporcionais às de biossólido que foram aplicadas, como resultado provável da interferência de outros fatores, tais como, o desenvolvimento vegetativo e as alterações promovidas nas características físicas e químicas dos solos pela adição do resíduo.

Anjos \& Mattiazzo (2000), num experimento utilizando dois latossolos pertencentes a diferentes classes texturais, com o biossólido sendo aplicado e incorporado, na camada de 0-20 cm do solo contido em vasos, repetidas vezes até um total de $388 \mathrm{t}$ ha-1 ${ }^{-1}$ observaram elevação significativa do teor de $\mathrm{N}^{-\mathrm{NO}_{3}}{ }^{-}$presente no líquido percolado através de ambos os solos, os quais chegaram a atingir valores de até $96 \mathrm{mg} \mathrm{L}^{-1}$ de 
$\mathrm{NO}_{3}$. Essa elevação no teor de nitratos representa um risco potencial para a contaminação de águas subterrâneas.

Oliveira et al. (2001), em um experimento em condições de campo, utilizando um solo de textura média onde o biossólido foi aplicado em taxas de até $99 \mathrm{t} \mathrm{ha}^{-1}$ no primeiro ano de cultivo e de até $110 \mathrm{t} \mathrm{ha}^{-1}$ no segundo ano, observaram, a $90 \mathrm{~cm}$ de profundidade, concentrações de nitrato maiores do que as do padrão estabelecido pela Organização Mundial da Saúde (OMS) para águas potáveis, que é de $10 \mathrm{mg} \mathrm{L}^{-1}$, evidenciando o potencial para contaminação de aqüíferos pelo nitrato proveniente da mineralização do nitrogênio orgânico contido no biossólido.

Diferenças na porcentagem de lixiviação de nitrogênio em função do tipo de lodo e sistema de aplicação (lodo liquido digerido anaeróbio injetado ou aplicado superficialmente em dose de $125 \mathrm{~m}^{3}$ ha ${ }^{-1}$ e lodo liquido bruto injetado no solo em dose de $140 \mathrm{~m}^{3} \mathrm{ha}^{-1}$ ) foram observadas por Missekbrook et al. (1996), sendo que a concentração de nitratos na solução do solo, a $90 \mathrm{~cm}$ de profundidade, para o lodo digerido e injetado no solo, excedeu os limites permissíveis pela União Européia (11,3 $\left.\mathrm{mg} \mathrm{L}^{-1}\right)$.

A possibilidade de formação e lixiviação de nitratos e a importância ambiental desse fenômeno tornaram necessário o estabelecimento de um parâmetro para determinar a quantidade de biossólido possível de ser aplicada com segurança no solo agrícola com vistas a prevenir a poluição das águas subterrâneas (Carneiro et al., 2003; Andrade, 1999). Esse parâmetro, denominado taxa ou fração de mineralização do nitrogênio (TMN ou FM), é dependente do tipo de lodo e das condições edafoclimáticas do local, com particular destaque para o $\mathrm{pH}$ e a atividade microbiana do solo onde ele será aplicado, temperatura, umidade e aeração do meio. A determinação da taxa de mineralização, pode ser feita por ensaios de incubação em laboratório, com ou sem lixiviação (Beauchamp et al., 1986; Parker \& Sommers, 1983; Stanford \& Smith 1972) e na sua determinação não se leva em conta a espécie vegetal presente ou a ser plantada no local, que é um fator de grande importância no estabelecimento da dose.

A sincronia entre a reação de mineralização do nitrogênio fornecido pelo biossólido e a absorção desse nutriente pelas plantas é um fator importante que deve ser considerado no cálculo da dose de biossólido a ser aplicada ao solo agrícola, conforme 
evidenciado no trabalho de Medalie et al. (1994), após aplicar ao solo doses de até $14,5 \mathrm{t} \mathrm{ha}^{-1}$ de um biossólido que continha $60 \mathrm{~g} \mathrm{~kg}^{-1}$ de $\mathrm{N}$ total.

Cox (1995), estudando o aporte de N procedente de diferentes fontes (fertilizante inorgânico de liberação controlada, fertilizante inorgânico altamente solúvel; biossólido proveniente de tratamento primário e biossólido de tratamento secundário) para distintas culturas, observou que os biossólidos forneceram, de forma segura, adequadas quantidades de $\mathrm{N}$ para plantas de crescimento lento e baixa taxa de absorção de $\mathrm{N}$, entretanto para plantas de rápido crescimento e elevadas taxas de absorção de $\mathrm{N}$, estes deveriam ser combinados com fertilizantes nitrogenados solúveis tendo em vista que, a curto prazo, os biossólidos testados não se mostraram como fontes eficientes de N. A ineficiência no fornecimento de nitrogênio do biossólido para plantas de milho foi observada por Anjos \& Mattiazzo (2000).

A possibilidade de imobilização do $\mathrm{N}$ mineralizado do biossólido por microrganimos do solo foi investigada por Vieira \& Cardoso (2003) num experimento com doses crescentes de lodo de esgoto em Latossolo Vermelho Distroférrico plantado com milho. Os autores não encontraram diferenças significativas nos teores de $\mathrm{N}$ contido na biomassa microbiana, nos primeiros $20 \mathrm{~cm}$ do solo, em função da incorporação do lodo de esgoto, descartando-se assim a possibilidade de que grandes quantidades de $\mathrm{N}$ tenham sido imobilizadas pela microbiota do solo, nos primeiros 150 dias após a emergência do milho.

Silva et al. (1999), observaram que a correção da acidez do solo (de dois Latossolos Vermelho-Amarelos por eles estudados), mediante utilização de $\mathrm{CaCO}_{3}$, resultou em aceleração do processo de mineralização e em diminuição das quantidades de N imobilizado. Nyborg \& Hoyt (1978) e Dancer et al. (1973) também observaram o efeito temporário da calagem no sentido de acelerar o processo de mineralização de $\mathrm{N}$, efeito que tem sido associado à elevação dos valores de pH e à diminuição do $\mathrm{Al}$, com conseqüente aumento da atividade de organismos mineralizadores.

Boeira (2000), em experimento conduzido em cultivo de milho em solo argiloso, verificou que mesmas quantidades de nitrato movimentaram-se no perfil do solo quando utilizado lodo de esgoto ou adubação mineral convencional, ou mesmo no caso de nenhuma aplicação de adubos. Assim, seguindo-se as recomendações obtidas pela pesquisa, a utilização de lodo de esgoto como adubo nitrogenado pode trazer 
benefícios ao produtor, por ser uma fonte de nutrientes barata, e também ao meio ambiente, por aliviar a carga de esgotos nos mananciais de água.

\subsubsection{Metais pesados}

Embora de procedência predominantemente doméstica, é freqüente encontrar metais pesados nos biossólidos. São classificados como metais pesados os elementos químicos, de caráter metálico, que apresentem densidade atômica maior que $5 \mathrm{~g} \mathrm{~cm}^{-3}$. Dentre esses elementos alguns são nutrientes de plantas, caso do $\mathrm{Cu}, \mathrm{Zn}, \mathrm{Fe}, \mathrm{Mn}$ e Mo. A esses se somam outros elementos metálicos que apresentam uma toxicidade intrínseca associada a seu nome tal como $\mathrm{Cd}, \mathrm{Pb}$ e $\mathrm{Hg}$ e outros elementos de transição da tabela periódica considerados potencialmente tóxicos a seres vivos, e que também estão presentes neste resíduo e cujos conteúdos deverão ser vigiados na hora de aplicação do biossólido. Devido ao potencial de causar toxicidade a seres vivos outros elementos que não apresentam caráter metálico são usualmente mencionados como integrantes da categoria dos metais pesados como é o caso do As e do Se (Mattiazzo-Prezotto, 1992).

A toxicidade dos metais pesados ou elementos potencialmente tóxicos depende do teor e da forma química sob a qual eles se apresentam no biossólido e, depois, no solo sendo esta última dependente das diferentes interações existentes no meio.

Bertoncini (2002), mediante extrações seqüenciais realizadas no biossólido procedente da ETE-Barueri, originado de esgoto doméstico gerado pela grande de São Paulo, após digestão aeróbica, anaeróbica e condicionamento com $\mathrm{Ca}(\mathrm{OH})_{2}$ e $\mathrm{FeCl}_{3}$, estudou a distribuição dos metais $\mathrm{Cd}, \mathrm{Cr}, \mathrm{Cu}, \mathrm{Ni}$ e $\mathrm{Zn}$. Os resultados obtidos mostraram que o $\mathrm{Cd}$ encontrava-se principalmente ligado à fração carbonatada $(58,3 \%)$ e o resto à fração residual. O Cr presente no biossólido estava ligado preferencialmente à fração residual (33,7\%), seguido da fração oxido $(23,6 \%)$ e da fração orgânica (20\%). Cu apresentou-se ligado, principalmente, à fração orgânica (74,5\%), seguido das formas residual $(20,6 \%)$, carbonatada $(9,2 \%)$, oxidos $(7,4 \%)$ e uma pequena porcentagem na forma trocável (1,5\%). O Ni apresentou uma distribuição mais homogênea entre as diferentes frações: orgânica (32,6\%), óxidos (22,8\%), residual $(19,6 \%)$ e carbonatada (17,9\%). Já a participação da formas trocáveis foi

mínima (1,7\%). O Zn não apresentou distribuição preferencial por nenhuma das frações estudadas, sendo que a fração óxidos representou 25,9 \%, a fração carbonatos 
22,6\%, a fração orgânica 22,2\% e a fração residual 12,1\% do total de Zn no biossólido. Considerando que o biossólido avaliado apresentava um $\mathrm{pH}=12$, a predominância dos metais ligados a fração carbonatos poderia ser esperada, entretanto são necessárias previsões acerca da permanência do metal ligado a essa forma com a adição desse material a solos ácidos, como é o caso de solos sob clima tropical. A mesma consideração pode ser feita acerca da permanência do metal ligado a fração orgânica.

Uma vez no solo, múltiplos são os fatores existentes no meio e que afetam a distribuição dos metais pesados. A Figura 1, adaptada de Mattigod et al., (1981) resume as várias reações que ocorrem no sistema e que regulam a quantidade do metal presente na forma livre, que seria a forma do metal de maior mobilidade e disponibilidade às plantas e outros organismos (Kabata-Pendias, 1995).

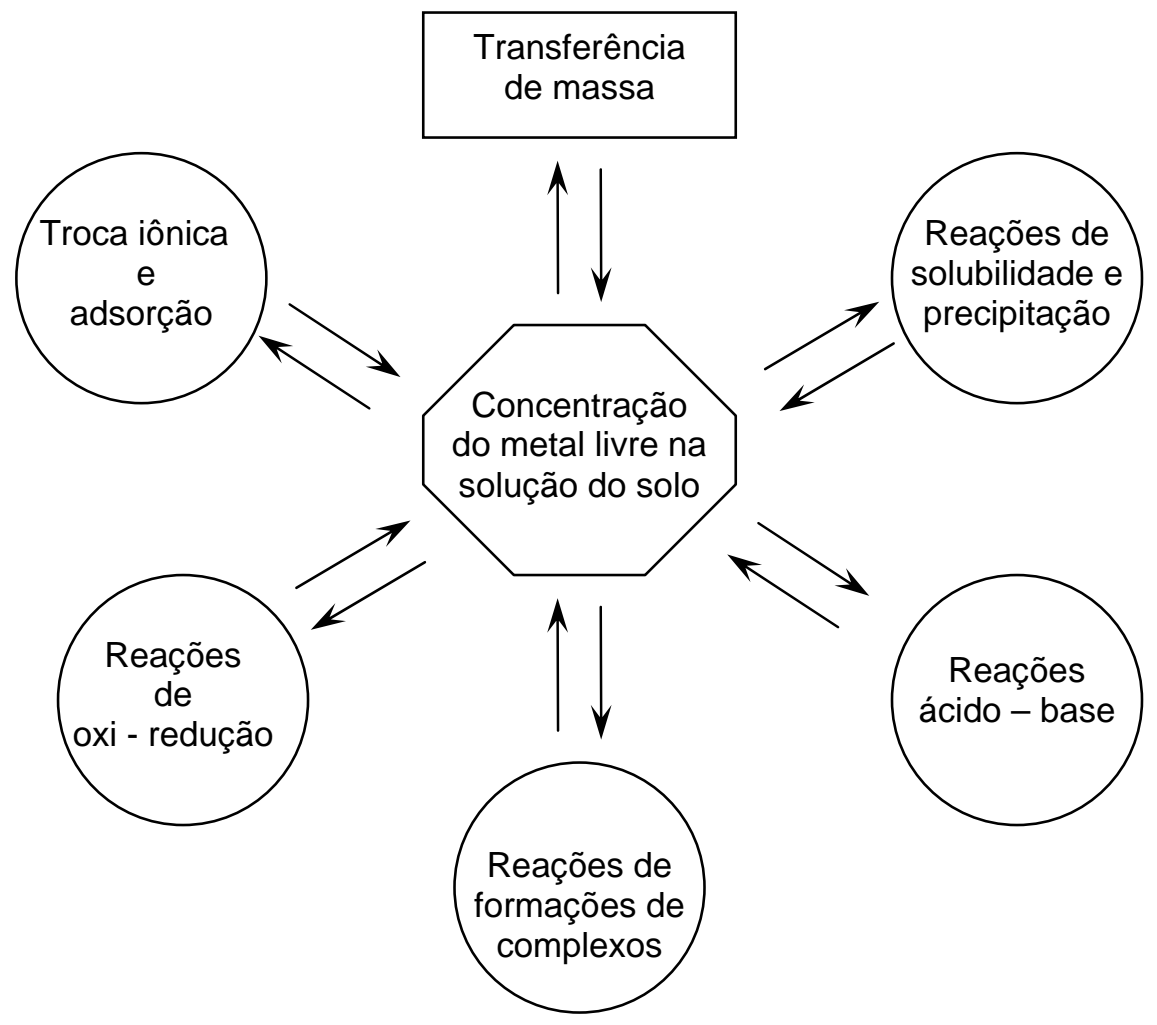

Figura 1 - Representação esquemática das reações que controlam o teor de metais presentes na solução do solo. Adaptada de MATTIGOD et al. (1981) 
As possibilidades dos inúmeros equilíbrios existentes fazem com que os metais pesados possam ocorrer no solo sob diversas formas: em forma iônica ou complexada na solução do solo, genericamente denominadas formas livres do metal, como íons trocáveis ligados ao material orgânico, inorgânico ou organomineral presentes no solo, como íons mais firmemente ligados aos complexos de troca, como parte integrante de complexos orgânicos, coprecipitados em sesquióxidos de ferro, alumínio e manganês, precipitados como sais insolúveis, incorporados em microorganismos e nos seus resíduos biológicos, ou presos nas estruturas cristalinas dos minerais primários ou secundários (Kabata-Pendias \& Pendias, 1992; Adriano, 1986).

Das diferentes formas possíveis de estar presentes em solos, as formas adsorvidas são provavelmente as mais importantes na química dos metais pesados no solo. A quantidade de cátions que pode ser adsorvida por troca de íons da solução pela fase sólida (ou CTC) é dependente das espécies envolvidas, sendo que, quanto maior a CTC do solo, maior a sorção e imobilização dos metais (Lasat, 2000; Sposito, 1989).

As espécies de metais pesados presentes em solução sob formas iônicas ou formando complexos solúveis são as mais móveis no solo, e governam sua mobilidade e fitodisponibilidade. Em geral, no solo $\mathrm{Cd}$, Zn, Ni e Mn se apresentam mais móveis que $\mathrm{Cu}, \mathrm{Cr}$ e $\mathrm{Pb}$; por serem aqueles retidos mais fracamente pelos minerais de argila, óxidos/hidróxidos do solo e por formarem complexos solúveis com ligantes orgânicos e inorgânicos (Simão \& Siqueira, 2001; Alloway \& Ayres, 1997) e também por não formarem, nas condições ácidas dos solos sob clima tropical, compostos de baixa solubilidade (Mattiazzo-Prezotto, 1994). A capacidade do solo em reter metais aumenta com a elevação do $\mathrm{pH}$, favorecendo a precipitação, diminuindo assim sua concentração na solução do solo e a mobilidade e absorção destes elementos pelas plantas (Simão \& Siqueira, 2001).

Bertoncini (2002), realizando extração seqüencial de amostra de terra que recebera $388 \mathrm{t} \mathrm{ha}^{-1}$ de biossólido, distribuído em sucessivas aplicações e incorporado nos primeiros $20 \mathrm{~cm}$ do solo, observou que, sete meses após da última aplicação do biossólido, em Latossolo Vermelo-Amarelo Distrófico, $\mathrm{Cd}$ se encontrou, na sua totalidade, na fração carbonatada e, apenas, na superfície do solo. A ausência de $\mathrm{Cd}$ nas frações orgânica, óxidos e residual foi atribuído à competição com o cálcio pelos sítios de adsorção da superfície orgânica (Fletcher \& Beckett, 1987), dos óxidos de ferro e minerais (Alloway, 1995). O Cr foi retido de preferencialmente na fração 
orgânica, tanto na camada superficial $(56,2 \%)$ como na subsuperficial $(57,7 \%)$, e secundariamente às frações óxidos (13,6\%) e residual (12,5\%), na camada superficial. A autora salienta que a presença de $\mathrm{Cr}$ em profundidade, ligado possivelmente à fração orgânica móvel, pode chegar a representar riscos de lixiviação do metal. Segundo Bertoncini, os teores totais de Cu foram maiores no horizonte superficial, no obstante, foi verificado mobilização do elemento para o horizonte subseguinte. Já, analisando a distribuição do elemento nas distintas frações estudadas, foi observada ligação preferencial do Cu à matéria orgânica (65,8\% em superfície e 59,2\% em profundidade), seguida da fração carbonatada (16,5\% em superfície e 17,6\% em profundidade) e da fração óxidos (6,8\% em superfície e 9,1\% em profundidade). Apenas $0,4 \%$ do $\mathrm{Cu}$ esteve presente na fração trocável do solo na camada superficial. Os teores totais de $\mathrm{Ni}$ apresentaram-se significativamente maiores em superfície, embora tenha sido constatada mobilidade do elemento em profundidade associado à fração carbonatada e à fração orgânica. Ni apresentou-se ligado principalmente à fração orgânica (52,5\% em superfície e 64,3\% em profundidade), seguida da fração carbonatada (20,0\% em superfície e 30,3\% em profundidade) e óxidos (12,6\% em superfície e 17,3\% em profundidade). No que se refere ao Zn, Bertoncini observou, sua distribuição nas duas camadas de solo avaliadas (0-25 e 25-50 cm), reflexo da mobilidade do metal adicionado via biossólido. Zn apresentou-se predominantemente ligado à fração carbonatada nas duas profundidades (53,1\% em superfície e 58,0\% em profundidade). Em superfície, $\mathrm{Zn}$ foi encontrado secundariamente ligado à fração orgânica $(20,5 \%)$ seguindo-se das frações óxidos $(9,4 \%)$ e residual $(7,8 \%)$. Em profundidade, Zn esteve retido secundariamente às frações óxidos (12,3\%) e residual $(9,9 \%)$ e à fração orgânica (4,5\%). Como se pode constatar pelo trabalho de Bertoncini (2002) a distribuição dos metais no solo é semelhante àquela que o metal estava presente no biossólido.

A concentração de metal nas partes aéreas das plantas, em relação à concentração existente no solo, pode ser indicativa de sua fitodisponibilidade e tem sido demonstrado pela pesquisa que $\mathrm{Cd}$ e $\mathrm{Zn}$ possuem os maiores coeficientes de transferência para as plantas, enquanto que metais como $\mathrm{Cu}$ e $\mathrm{Cr}$ são menos disponíveis (Lasat, 2000; Alloway \& Ayres, 1997).

A presença de diferentes metais no solo pode dar origem a reações de sinergismo e antagonismo. Assim, o Zn compete pelos mesmos sítios de absorção que o Cd, 
resultando na diminuição da absorção Cd nas raízes. Ao mesmo tempo Cd é capaz de substituir ao Ni durante o processo de absorção. A absorção de Ni também pode ser inibida pelas espécies $\mathrm{Cu}^{2+}$ e $\mathrm{Zn}^{2+}$. Já, $\mathrm{Cu}$ e o $\mathrm{Cd}$ apresentam uma relação que pode ser tanto antagônica quanto sinérgica (Accioly \& Siqueira, 2000; Berton, 1992; KabataPendias \& Pendias, 1992).

Após aplicar doses de 0 a $40 \mathrm{Mg} \mathrm{ha}^{-1}$ de lodo de esgoto, no sulco do plantio, em um Argissolo Vermelho-Amarelo Distrófico, Silva et al. (2001) concluíram que o lodo de esgoto aumentou os teores de metais pesados do solo, mas estes permaneceram aquém dos valores considerados perigosos ao ambiente. Martins et al. (2003) avaliaram os efeitos da aplicação sucessiva de lodo de esgoto, em um Latossolo Vermelho Distrófico típico com e sem calagem, sobre a acumulação e fitodisponibilidade de metais pesados em milho, num estudo a campo durante quatro anos. Os autores concluiram que os teores extraíveis de $\mathrm{Cu}, \mathrm{Ni}$ e $\mathrm{Zn}$ no solo aumentaram linearmente com as doses de lodo de esgoto, para os dois extratores usados (DTPA e Mehlich-3), e que a adição de lodo de esgoto elevou os teores totais de $\mathrm{Cu}$ e $\mathrm{Zn}$, mas não afetou os teores de Ni no solo. Pela sua parte, Oliveira \& Mattiazzo (2001), após aplicações de lodo de esgoto durante dois anos, num Latossolo Amarelo Distrófico, não observaram evidências de mobilidade para os metais Cu e Cr, enquanto que o Zn mostrou-se um elemento móvel no perfil do solo. Num estudo sobre os níveis de lixiviação de metais fornecidos ao solo por lodo, proveniente de tratamento por lagoas de estabilização, Isea et al. (2000), encontraram que Cd e Ni se movimentaram em profundidade no solo, sendo que esse fenômeno não foi observado para o $\mathrm{Cr}$, o qual foi acumulado na superfície solo.

Mattiazzo-Prezotto (1994) estudando o comportamento de Cd, Cu, Cr, Ni e Zn, sob forma de sais solúveis, adicionados a solos contidos em tubos de percolação, concluiu que os teores de óxidos de ferro e alumínio do solo foram fundamentais na retenção dos metais adicionados. O autor recomenda que em solos arenosos com baixo conteúdo de óxidos não deveriam ser utilizados resíduos contendo metais, entre os que se inclui o biossólido. Essa conclusão mostra a necessidade de estudos sobre a movimentação de metais nesse tipo de solo. 


\subsubsection{Outras considerações sobre biossólido}

A matéria orgânica posiciona-se como um dos fatores de maior influência nas características dos solos, sendo a principal responsável pela estruturação física, devido à melhoria na agregação das partículas e a estabilidade de agregados, favorecendo assim a infiltração de água no perfil, a aeração e a retenção de umidade, melhorando sua resistência à erosão e à seca, além de ativar a vida microbiológica do solo e, possivelmente, aumentando a resistência das plantas às pragas. Também intervém favoravelmente na fixação, complexação ou quelação de elementos tóxicos, como os metais pesados, tornando-os indisponíveis para as plantas (Raij, 1998; Wang, 1997; Ayuso et al., 1996; Henry et al., 1994; Kiehl, 1985; Carvalho \& Barral, 1981; Sabey, 1974). O papel da matéria orgânica na CTC dos solos é mais acentuado nas regiões tropicais tornando mais atrativo o uso de biossólido na agricultura destas áreas (Melo et al., 1994). Assim, o biossólido pode ser considerado como um material com certas propriedades e características próprias da matéria orgânica, tais como, elevada superfície específica, carga líquida negativa dependente do $\mathrm{pH}$ do meio, facilidade de embebição de água e da solução do solo contendo metais, e capacidade de formar quelatos orgânicos (Simão \& Siqueira, 2001; Bertoncini \& Mattiazzo, 1999).

Segundo Cardoso Vigueros (2002), quando lodo de esgoto tratado é aplicado na camada arável do solo, são observadas alterações nas características físico-químicas nos 30 primeiros centímetros do solo, tais como neutralização da acidez, incremento da condutividade elétrica, da matéria orgânica, da CTC e da porosidade. Barbosa et al. (2002), após dois anos de incorporações de lodo anaeróbico num Latossolo Vermelho eutroférrico, concluíram que existe uma tendência de aumento da agregação do solo e da macroporosidade e de redução da densidade do solo e da microporosidade, porém sem diferenças estatisticamente significativas entre os tratamentos que receberam biossólido. Aumento na fertilidade do solo após aplicação de lodo de esgoto foi observado por Silva et al (2001) e justificado pelo papel deste material na diminuição da acidez, no aumento da CTC efetiva e no fornecimento de nutrientes, principalmente de Ca, P, S e Zn.

Não obstante, o tipo de material orgânico existente no biossólido, a capacidade deste como fornecedor de nutrientes para as plantas e efeito desta fração orgânica sobre a CTC do solo onde aplicada, ainda são questões de duvidosa resposta. Oliveira et al. (2002), sugerem que o efeito do lodo de esgoto na elevação do pH do solo é o 
responsável pela elevação da CTC e atribuem nenhum efeito do material orgânico nele presente. Os dados de Oliveira et al. (2002), encontram suporte no trabalho de Bertoncini (2002), que concluiu que a incorporação de sucessivas doses de biossólido ao solo promoveu alterações qualitativas de maneira diferenciada nas frações húmicas avaliadas, resultando no aumento da quantidade de grupamentos carboxílicos e fenólicos, que não apresentam capacidade de retenção de cátions no $\mathrm{pH}$ usual de solo sob clima tropical.

\subsubsection{Biossólido em sistemas florestais}

Os ecossistemas florestais apresentam vários atributos positivos perante a recepção de biossólido. Entre eles destacam a elevada produção e distribuição de carbono orgânico em seus componentes, capazes de imobilizar grandes quantidades de nutrientes e metais pesados, e a grande quantidade de raízes perenes explorando amplo volume do solo, permitindo a absorção de nutrientes e metais pesados durante todo o ano nas regiões tropicais. Entre os inconvenientes que podem limitar sua aplicação ressaltam o uso das florestas como áreas públicas e de recreação, expondo os visitantes a contaminações, principalmente por patógenos, e a possibilidade dos metais pesados serem absorvidos por cogumelos e sementes comestíveis, elevando os riscos de contaminação da fauna e de usuários da floresta (Vaz \& Gonçalves, 2002b). Múltiplas pesquisas vêm testando a aplicação de biossólido no cultivo de eucalipto e mostram que este material age como fonte de nutrientes para as plantas e de matéria orgânica para o solo. Esses trabalhos concluem que, enquanto o adubo comercial está se esgotando, o biossólido começa a agir no solo e seu efeito é mais prolongado, pois ele libera os nutrientes gradativamente (Revista da Madeira, 2003). Zen et al. (1994) encontraram, em Eucalyptus grandis, um ganho volumétrico e um aumento de produtividade ao variar a dose e o modo de aplicação de composto de lixo urbano, no norte do Estado de São Paulo. Vaz \& Gonçalves (2002a) constataram que a aplicação, em plantação de eucalipto, de doses crescentes de biossólido resultou numa resposta quadrática em termos de produtividade de madeira com casca. Aos 17 meses de idade, 13 meses pós-aplicação do biossólido, o crescimento em volume elevou-se quando comparado o tratamento controle com o que recebeu maior dose de biossólido, sendo tal efeito atribuído, principalmente, à aplicação deste material. Comparando o crescimento das árvores aos 17 e 24 meses de idade, os autores 
constataram que a resposta à aplicação de biossólido elevou-se com a idade, refletindo, principalmente, efeitos benéficos devidos à elevação da disponibilidade de nutrientes, oriundos da solubilização e mineralização de componentes deste resíduo, bem como a um maior volume de exploração do solo pelas raízes, o que aumentou o acesso a esses nutrientes.

\subsection{0 projeto de Itatinga}

Em 1998 foi iniciado na Estação Experimental de Itatinga, SP, um projeto multidisciplinar, fruto do convênio firmado entre o Instituto de Pesquisas e Estudos Florestais (IPEF), ESALQ/USP e a Companhia de Saneamento Básico do Estado de São Paulo (SABESP). Este projeto, que conta com a participação de vários pesquisadores com múltiplos interesses, tem como ponto em comum um experimento onde biossólido, produzido na ETE-Barueri, localizada em Barueri/SP e gerenciada pela SABESP, foi aplicado em um Latossolo Vermelho-Amarelo Distrófico típico, A moderado, textura média, cultivado com eucalipto. O presente estudo foi desenvolvido na área desse projeto.

Para a montagem do experimento foi escolhida uma área com Eucalyptus saligna, de aproximadamente 50 anos de idade, e que fora, durante esse período, submetida a vários ciclos de corte. Para implantar o ensaio fez-se o corte das árvores, recolheu-se a madeira produzida e na área reformada, em sistema de cultivo mínimo, foram plantadas mudas originadas de sementes de Eucalyptus grandis nas entrelinhas do cultivo anterior.

As parcelas experimentais estabelecidas seguiram um delineamento em blocos aleatorizados, com 9 tratamentos e 4 repetições, num total de 36 parcelas. Em março de 1998 foram plantadas, em cada parcela 100 mudas de Eucalyptus grandis (10 linhas com 10 plantas cada). As parcelas apresentam bordadura dupla, ficando como área útil de cada uma apenas as 36 plantas centrais.

A quantidade total do biossólido foi aplicada em julho de 1998, a lanço em cobertura, sem incorporação ao solo, nas entrelinhas de plantio (faixa de $2 \mathrm{~m}$ ), deixando, aproximadamente, meio metro de distância até as mudas, utilizando uma carreta puxada por trator.

Os tratamentos aplicados foram: controle, sem fertilização mineral e sem aplicação de biossólido; adubação mineral; 5 t ha ${ }^{-1}$ de biossólido, complementado com potássio; 
$10 \mathrm{t} \mathrm{ha}^{-1}$ de biossólido, complementado com potássio; $10 \mathrm{t} \mathrm{ha}^{-1}$ de biossólido, sem complementação de potássio; 10 t ha $^{-1}$ de biossólido, complementado com potássio e fósforo; $15 \mathrm{t} \mathrm{ha}^{-1}$ de biossólido, complementado com potássio; $20 \mathrm{t} \mathrm{ha}^{-1}$ de biossólido, complementado com potássio; 40 t ha $^{-1}$ de biossólido, complementado com potássio. As doses mencionadas do biossólido são apresentadas em base seca.

Dos vários estudos desenvolvidos a partir deste experimento cabe ressaltar as seguintes conclusões:

- não houve movimentação de nitratos no perfil vertical do solo, provocada pela adição de biossólido em doses até $40 \mathrm{t} \mathrm{ha}^{-1}, 360$ dias após aplicação do material (Andrade \& Mattiazzo, 2000).

- a aplicação de doses crescentes de biossólido, até $40 \mathrm{t} \mathrm{ha}^{-1}$, proporcionou 0 aumento na disponibilidade de $\mathrm{N}$ às árvores de Eucalyptus grandis. A fitodisponibilidade $\mathrm{Cu}$, Ni e Zn não foi alterada em função das doses de biossólido aplicadas, 360 dias após aplicação do material (Andrade \& Mattiazzo, 2000).

- o único metal a se movimentar no perfil vertical do solo, em função da dose de biossólido aplicada, foi o Zn, 360 dias após aplicação do material (Andrade \& Mattiazzo, 2000).

- a aplicação de biossólido modificou o estado nutricional das plantas de eucalipto. Aquelas que receberam as maiores doses de biossólido, apresentaram teores foliares mais elevados de N, 16 meses após aplicação do biossólido (Guedes, 2000).

- nos tratamentos com as maiores doses de biossólido foi verificado o aumento da produção de folhedo e conseqüente deposição de nutrientes, bem como a decomposição do folhedo acumulado sobre o solo, alterando o processo de ciclagem biogeoquímica, até dois anos após aplicação do biossólido (Guedes, 2000).

- após 32 meses da aplicação, o biossólido afetou positivamente a nutrição das plantas de eucalipto, gerando ganhos de produtividade superiores à obtida com adubação mineral (Rocha, 2002).

- aos 6 e 13 meses após aplicação do biossólido, com aumento da dose de biossólido, ocorreu redução de dos teores de matéria orgânica, somente na camada 0$5 \mathrm{~cm}$ do solo. Em compasso com a mineralização da matéria orgânica no solo, o teor de $\mathrm{N}$ no tecido foliar aumentou com a dose de biossólido aplicada em ambas às épocas de amostragem (Faria, 2000). 
- a aplicação de fertilizante fosfatado conjuntamente com o biossólido mostrou-se necessária para o desenvolvimento inicial das mudas, mas a suplementação potássica em plantas jovens de eucalipto poderá não ser necessária para doses maiores que $10 \mathrm{t} \mathrm{ha}^{-1}$ de biossólido, quando as concentrações de $\mathrm{K}$ trocável no solo forem médias (0.08 - $\left.0.10 \mathrm{mmol}_{\mathrm{c}} \mathrm{dm}^{-3}\right)$ (Faria, 2000).

- existem povoamentos no entorno de Barueri suficientes para consumir toda a produção de biossólido dessa ETE, em distância de transporte economicamente viáveis, quando considerados cenários favoráveis financeiramente (Faria, 2000).

- são necessários estudos em longo prazo quando se considera o uso florestal do biossólido (Andrade, 1999). 


\section{MATERIAL E MÉTODOS}

\section{1 Área experimental - Clima e solo}

A área do estudo está situada na Estação Experimental de Ciências Florestais de Itatinga, da ESALQ/USP, (23 10' latitude Sul, 48 40' longitude oeste), a 200 km aproximadamente da cidade de São Paulo. O seu relevo é suavemente ondulado com uma altitude de $857 \mathrm{~m}$. O clima é tipo Cwa, segundo a classificação de Köppen, isto é, mesotérmico de inverno seco, com temperatura média do mês mais frio (julho) inferior a $18^{\circ} \mathrm{C}$ e temperatura média do mês mais quente (janeiro) superior a $22^{\circ} \mathrm{C}$. A precipitação média anual é cerca de $1.300 \mathrm{~mm}$ e o total de chuvas do mês mais seco não ultrapassa $30 \mathrm{~mm}$. Na Figura 2 são apresentados os dados climáticos coletados na estação meteorológica situada na própria estação experimental de Itatinga.

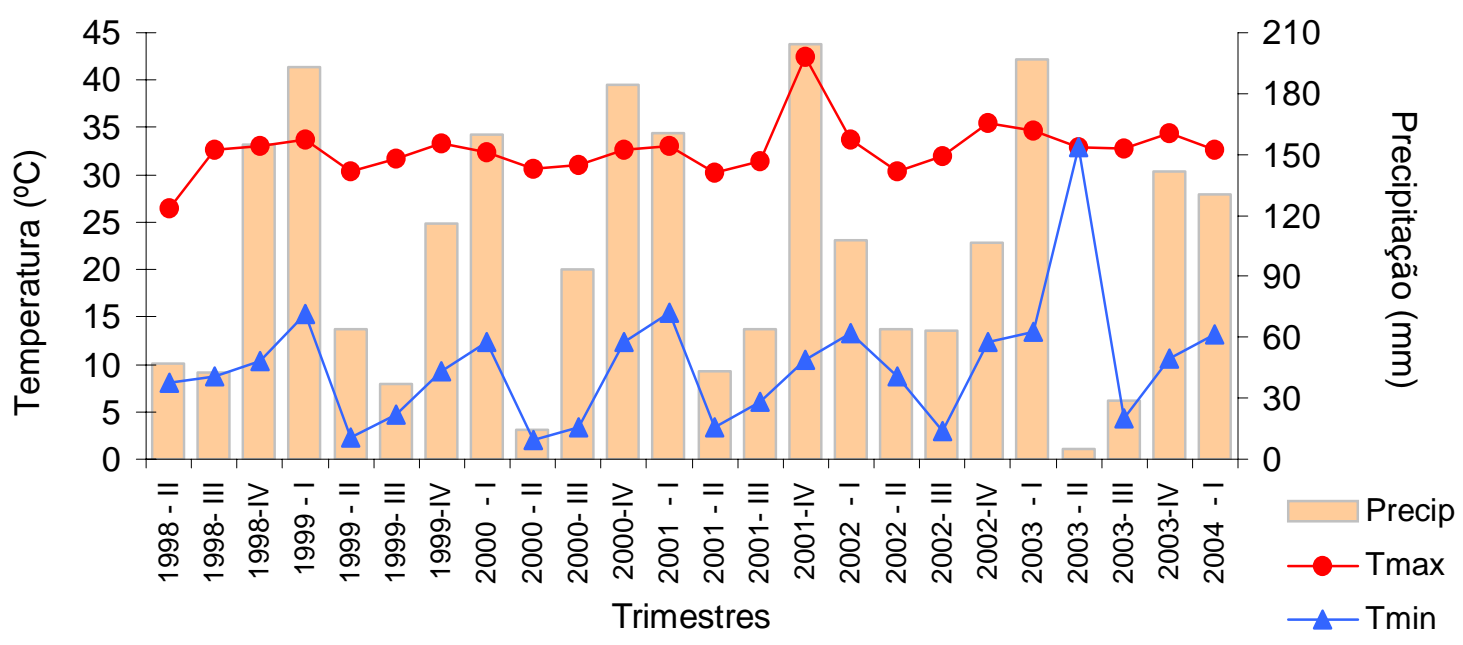

Figura 2 - Médias trimestrais da temperatura máxima (Tmax) e temperatura mínima (Tmin) e valores de pluviometria (Precip) acumulados no trimeste, durante o período de estudo. 
O solo no qual desenvolve-se o ensaio foi caracterizado como Latossolo VermelhoAmarelo Distrófico típico, A moderado, textura média (Gonçalves, 2003). Nas Tabelas 2 e 3 são apresentadas algumas características químicas e granulométricas do solo utilizado no experimento, em 3 profundidades, determinadas de acordo com Raij e Quaggio (1983) e Camargo et al. (1986). Na Tabela 3 também aparece o teor de óxidos do solo determinado mediante ataque sulfúrico de acordo com metodologia proposta por Camargo et al. (1986).

Tabela 2 Características químicas do solo utilizado no experimento

\begin{tabular}{|c|c|c|c|c|c|c|c|c|c|c|c|c|}
\hline Profundidade & $\mathrm{pH}$ & C & $\mathrm{P}$ & $\mathrm{K}$ & $\mathrm{Ca}$ & $\mathrm{Mg}$ & $\mathrm{H}+\mathrm{Al}$ & $\mathrm{Al}$ & SB & СТC & V & $\mathrm{m}$ \\
\hline $\mathrm{cm}$ & $\mathrm{CaCl}_{2}$ & $\mathrm{~g} \mathrm{dm}^{-3}$ & $\mathrm{mg} \mathrm{dm} \mathrm{m}^{-3}$ & --- & --- & ---1 & $\mathrm{~mol}_{\mathrm{C}} \mathrm{d}$ & & --- & ----- & $\%$ & $\%$ \\
\hline $0-30$ & 4,0 & 9,3 & 1 & 1,2 & 1 & 1 & 34,0 & 7 & 3 & 37 & 9 & 69 \\
\hline $30-60$ & 4,0 & 8,7 & 1 & 0,5 & 1 & 1 & 31,0 & 6 & 3 & 34 & 7 & 71 \\
\hline $60-90$ & 4,1 & 8,1 & 1 & 0,3 & 1 & 1 & 28,0 & 5 & 2 & 30 & 8 & 68 \\
\hline
\end{tabular}

Tabela 3 Granulometria e teores de óxidos de ferro, alumínio e silício determinados por ataque sulfúrico

\begin{tabular}{|c|c|c|c|c|c|c|c|}
\hline Profundidade & Argila & Areia grossa & Areia fina & Silte & $\mathrm{Fe}_{2} \mathrm{O}_{3}$ & $\mathrm{Al}_{2} \mathrm{O}_{3}$ & $\mathrm{SiO}_{2}$ \\
\hline $\mathrm{cm}$ & \multicolumn{7}{|c|}{ 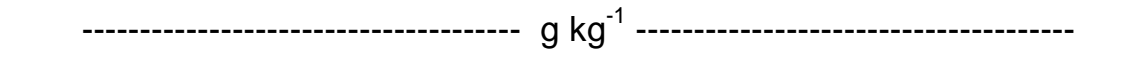 } \\
\hline $0-30$ & 168 & 532 & 241 & 59 & 25,0 & 64,0 & 45,0 \\
\hline $30-60$ & 190 & 495 & 266 & 49 & 27,4 & 64,0 & 47,0 \\
\hline $60-90$ & 197 & 496 & 278 & 29 & 28,8 & 76,0 & 48,0 \\
\hline
\end{tabular}

\subsection{Espécie florestal}

A espécie florestal empregada neste estudo, Eucalyptus grandis, foi escolhida pela importância econômica que representa no Estado de São Paulo para a produção de celulose, papel e madeira. Nesta região é geralmente cultivada em solos de baixa fertilidade natural, porém mostra respostas significativas quando fertilização com N, P e K (Novais et al., 1990), aspeto este também levado à consideração na escolha da espécie. As mudas de Eucalyptus grandis utilizadas no ensaio foram obtidas através da propagação de sementes da mesma espécie. 


\subsection{Biossólido}

O biossólido utilizado, procedente da ETE de Barueri (SP), é resultado do tratamento biológico de esgotos por processo denominado lodo ativado. A seguir o lodo é adensado e condicionado, mediante a adição de $\mathrm{FeCl}_{3}$ e cal hidratada, visando a coagulação de colóides de natureza orgânica e também a precipitação ou a coprecipitação de substâncias inorgânicas e metais presentes, para sua remoção dos esgotos, e favorecimento da desidratação em prensas hidráulicas como fase final. $O$ material aplicado foi caracterizado como biossólido tipo B (CETESB, 1999), dado que a densidade de coliformes fecais resultou inferior a $2 \times 10^{6} \mathrm{NMP} \mathrm{g} \mathrm{ST}^{-1}$.

Na Tabela 4 são apresentadas algumas características do biossólido, determinadas no Laboratório de Química Ambiental do Departamento de Ciências Exatas da ESALQ, de acordo com metodologia adaptada da descrita em Eaton et al. (1995).

\begin{tabular}{|c|c|c|}
\hline determinação & & valor \\
\hline pH em água & & 10,60 \\
\hline Umidade $65^{\circ} \mathrm{C}$ & $\mathrm{g} \mathrm{kg}^{-1}$ & 615,20 \\
\hline M.O. & $\mathrm{g} \mathrm{kg}^{-1}$ & 264,11 \\
\hline Carbono & $\mathrm{g} \mathrm{kg}^{-1}$ & 165,12 \\
\hline Nitrogênio total & $\mathrm{g} \mathrm{kg}^{-1}$ & 15,34 \\
\hline Nitrogênio inorgânico & $\mathrm{g} \mathrm{kg}^{-1}$ & 1,41 \\
\hline Relação C/N & & 11 \\
\hline Fósforo & $\mathrm{g} \mathrm{kg}^{-1}$ & 10,06 \\
\hline Potássio & $\mathrm{g} \mathrm{kg}^{-1}$ & 1,23 \\
\hline Cálcio & $\mathrm{g} \mathrm{kg}^{-1}$ & 149,95 \\
\hline Magnésio & $\mathrm{g} \mathrm{kg}^{-1}$ & 3,76 \\
\hline Sódio & $\mathrm{g} \mathrm{kg}^{-1}$ & 0,59 \\
\hline Cádmio & $\mathrm{mg} \mathrm{kg}^{-1}$ & 14 \\
\hline Zinco & $\mathrm{mg} \mathrm{kg}^{-1}$ & 1555 \\
\hline Cobre & $\mathrm{mg} \mathrm{kg}^{-1}$ & 394 \\
\hline Ferro & $\mathrm{mg} \mathrm{kg}^{-1}$ & 39763 \\
\hline Crômio & $\mathrm{mg} \mathrm{kg}^{-1}$ & 378 \\
\hline Níquel & $\mathrm{mg} \mathrm{kg}^{-1}$ & 227 \\
\hline
\end{tabular}

${ }^{\star}{ }^{*}$ Resultados expressos no material seco a $65^{\circ} \mathrm{C}$ 
O biossólido foi aplicado em julho de 1998 (4 meses após o plantio das mudas), a lanço em cobertura, sem incorporação ao solo, utilizando uma carreta puxada por trator. Como precaução, perante os elevados valores de pH e conteúdo em cálcio do biossólidos e para evitar que estes fatores pudessem ser prejudiciais ao crescimento inicial das mudas, o biossólido foi colocado nas entrelinhas de plantio, em faixa de $2 \mathrm{~m}$, aproximadamente, a meio metro de distância das mudas.

\subsection{Tratamentos e amostragem}

\subsubsection{Tratamentos}

Do total de unidades experimentais (36) do experimento inicial, foram amostradas 26 parcelas, contemplando 6 tratamentos distribuídos em 4 blocos. Os tratamentos amostrados foram:

- Controle: sem fertilização mineral e sem aplicação de biossólido (C)

- Adubação mineral (AM);

- 10 t ha ${ }^{-1}$ de biossólido, complementado com potássio (10+K);

- 10 t ha ${ }^{-1}$ de biossólido, complementado com potássio e fósforo (10+KP);

- 20 t ha ${ }^{-1}$ de biossólido, complementado com potássio (20+K);

- 40 t ha ${ }^{-1}$ de biossólido, complementado com potássio (40+K).

A complementação com potássio foi feita nos tratamentos com biossólido uma vez que vários autores, entre eles Boaretto (1986) e Buting (1963), evidenciaram a necessidade de fertilização potássica quando da aplicação de biossólido, que contem baixos teores de potássio, em diferentes culturas. A complementação potássica foi realizada de forma que os tratamentos com biossólido contivessem os mesmos teores de potássio que o tratamento com adubação mineral.

$\mathrm{Na}$ Tabela 5 são apresentadas as quantidades de nutrientes e metais pesados adicionados aos diferentes tratamentos em função das distintas doses de biossólido e/ou fertilização mineral recebida. 
Tabela 5 Adição inicial de nutrientes e metais pesados $\left(\mathrm{kg} \mathrm{ha}^{-1}\right)$, via adubação mineral ou biossólido, aos tratamentos do experimento

\begin{tabular}{cccccccccc}
\hline Tratamento & $\mathrm{N}^{(1)}$ & $\mathrm{P}^{(1)}$ & $\mathrm{K}$ & $\mathrm{Ca}$ & $\mathrm{Cd}$ & $\mathrm{Cr}$ & $\mathrm{Cu}$ & $\mathrm{Ni}$ & $\mathrm{Zn}$ \\
\hline $\mathrm{C}$ & 0 & 0 & 0 & 0 & 0 & 0 & 0 & 0 & 0 \\
$\mathrm{AM}$ & 98,2 & 34,7 & 137,3 & 528,0 & 0 & 0 & 0 & 0 & 1,20 \\
$10+\mathrm{K}$ & 153,4 & 106,0 & 137,3 & 1449,5 & 0,14 & 3,78 & 3,94 & 2,27 & 15,55 \\
$10+\mathrm{KP}$ & 153,4 & 140,7 & 137,3 & 1449,5 & 0,14 & 3,78 & 3,94 & 2,27 & 15,55 \\
$20+\mathrm{K}$ & 306,8 & 212,0 & 137,3 & 2999,0 & 0,28 & 7,56 & 7,88 & 4,54 & 31,10 \\
$40+\mathrm{K}$ & 613,6 & 424,0 & 137,3 & 5998,0 & 0,56 & 15,12 & 15,76 & 9,08 & 62,20 \\
(1) Sem considerar a taxa de mineralização (para N) e a solubilização (para P) &
\end{tabular}

Na Figura 3 é apresentada a distribuição dos 6 tratamentos avaliados dentro dos 4 blocos da área experimental. Mais detalhes sobre a instalação e condução do experimento podem ser obtidos em Poggiani et al. (2000). O aspecto da parcela experimental pode ser observado nas Figuras 4.a e 4.b.

Caminho de terra

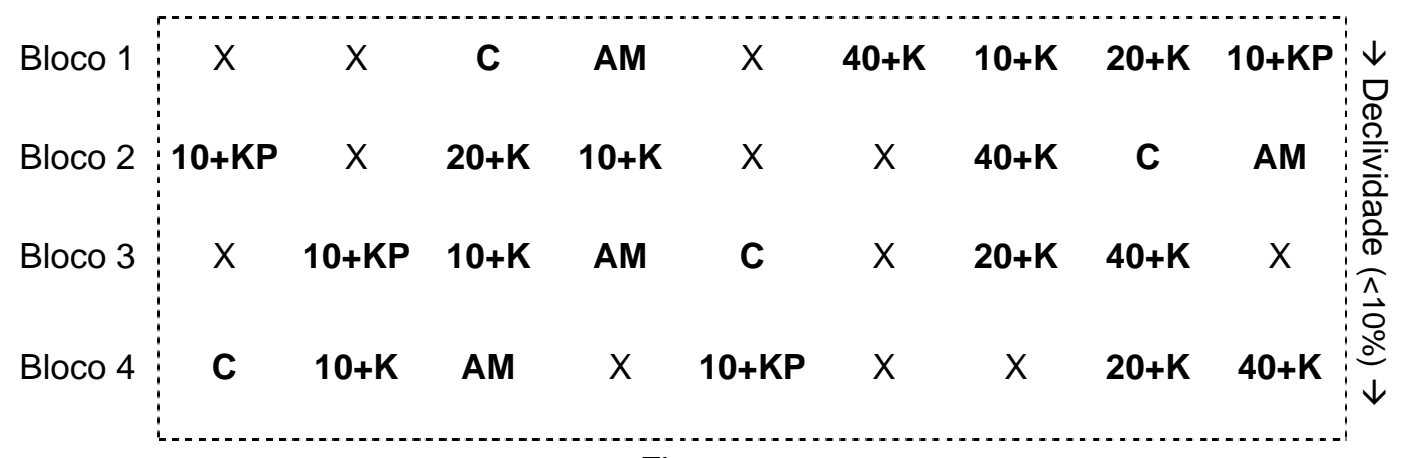

Floresta

Figura 3 - Distribuição das unidades experimentais 

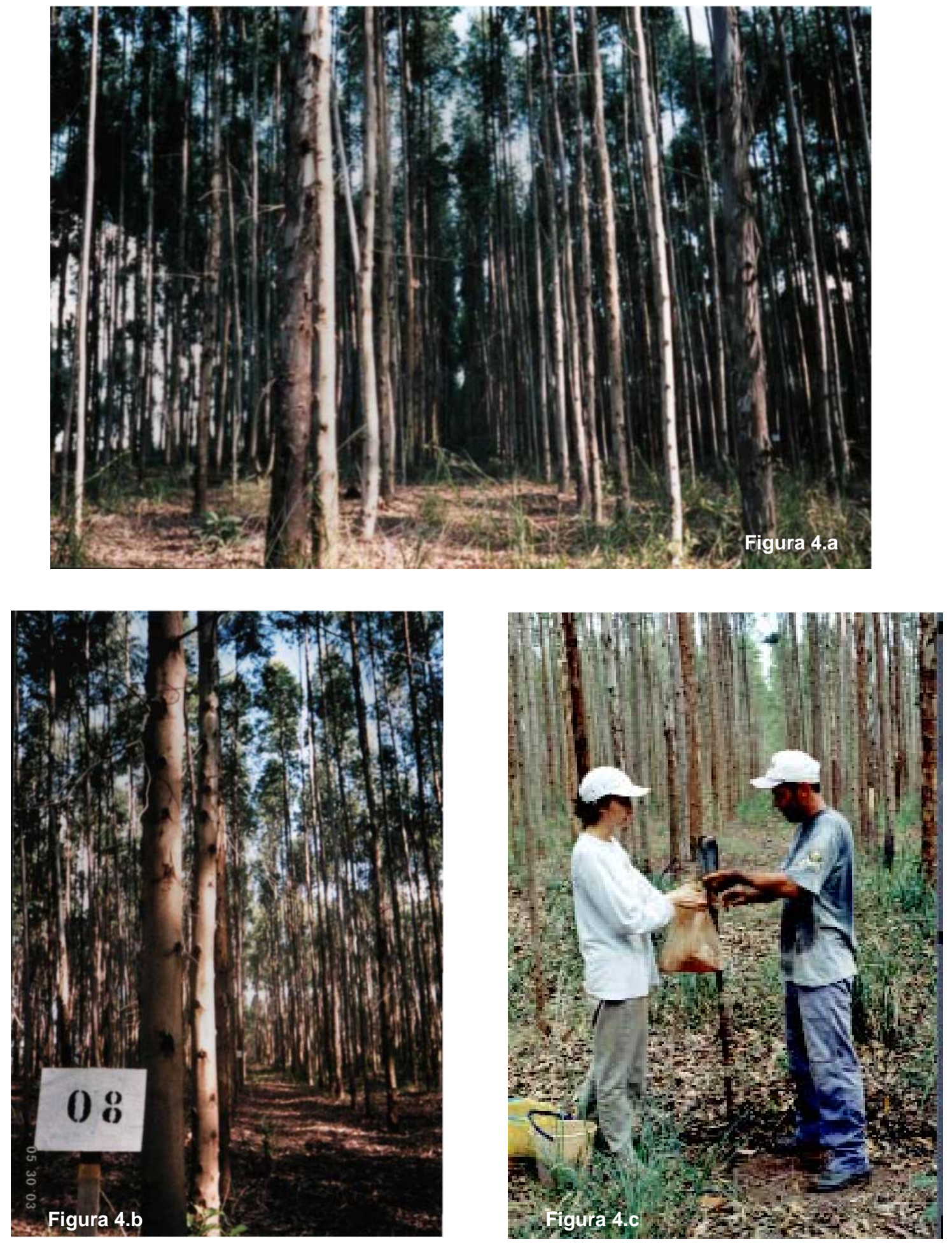

Figura 4 - Vistas parciais da parcela experimental (a e b) e detalhe da amostragem de solo (c) 


\subsubsection{Amostragem}

Foram feitas amostragens de solo e de folhas na área experimental conforme descrito a seguir:

a) solo: em fevereiro 2003, foi feita a amostragem, nas camadas 0-10, 10-20, 20-30, 30-60 e 60-90 cm de profundidade, com trado tipo holandês, retirando cuidadosamente serapilheira e outros restos da superfície antes da introdução do trado no solo. Coletaram-se 5 amostras simples dentro de cada parcela experimental, as quais foram misturadas a fim de obter, para cada profundidade, uma amostra composta (Figura 4.c). Esta foi dividida em duas amostras, sendo que uma delas foi armazenada sob refrigeração, para determinação de N-inorgânico ( $\mathrm{N}$ $\mathrm{NO}_{3}{ }^{-}+\mathrm{N}^{-} \mathrm{NH}_{4}{ }^{+}$) e a outra amostra foi seca ao ar, peneirada (malha $2 \mathrm{~mm}$ ) e homogeneizada para as demais determinações analíticas previstas.

b) folhas: foi feita uma coleta, em março 2003, derrubando as duas árvores mais representativas de cada parcela. Foram coletados os segundo e terceiro pares de folhas completamente desenvolvidas, a partir do ápice dos ramos, de quatro galhos inseridos na base do terço superior da copa, obtendo, assim, uma amostra com mais de 500 folhas. Após coleta, as folhas, incluindo pecíolos, foram secas a $65^{\circ} \mathrm{C}$ em estufa de ventilação forçada e moídas em moinho tipo Wiley (20 mesh).

\subsection{Análises químicas das amostras}

\subsubsection{Amostras de terra}

Foram avaliados para as amostras de terra:

a) teor extraível dos metais $\mathrm{Cd}, \mathrm{Cr}, \mathrm{Cu}, \mathrm{Ni}$ e $\mathrm{Zn}$ através da utilização da solução extratora denominada Mehlich 3 (Mehlich, 1984).

b) teor total dos metais $\mathrm{Cd}, \mathrm{Cr}, \mathrm{Cu}, \mathrm{Ni}$ e $\mathrm{Zn}$. As amostras foram processadas mediante digestão em microondas segundo metodologia proposta por Abreu et al. (2001).

A determinação dos teores de metais presentes nos extratos foi feita por espectrofotometria de absorção atômica (AA 12/1475 Intralab-Gemini).

c) teor de $\mathrm{N}$-inorgânico (nítrico+amoniacal), de acordo com metodologia proposta por Mulvaney (1996). 
d) teor de $\mathrm{N}$-total, determinado por combustão a seco $\left(1050^{\circ} \mathrm{C}\right)$ em aparelho LECO CN 2000.

\subsubsection{Amostras de tecido foliar}

Foram avaliados para as amostras de folha:

a) concentrações dos metais pesados $\mathrm{Cd}$, Cr, Cu, Ni e Zn. Para esta determinação as amostras foram submetidas à digestão com $\mathrm{H}_{2} \mathrm{O}_{2}+\mathrm{HNO}_{3}$ em microondas. $A$ quantificação do teor dos metais presentes no extrato foi feita por espectrofotometria de absorção atômica (AA 12/1475 Intralab-Gemini).

b) concentração de $\mathrm{N}$. As amostras de folhas foram submetidas à digestão sulfúrica segundo método de Kjeldahl (Tedesco et al., 1995).

\subsection{Tratamento estatístico dos dados}

Os resultados de análise terra (considerando cada profundidade amostrada) e de tecido foliar foram tratados estatisticamente para verificar possíveis diferenças das doses de biossólido sobre as variáveis estudadas, utilizando teste Tukey para comparação de médias (5\% de significância).

Realizaram-se análises de correlação entre as quantidades de $\mathrm{N}$ presentes nas folhas e as quantidades de $\mathrm{N}$-total e $\mathrm{N}^{-\mathrm{NO}_{3}}{ }^{-}$do solo, assim como entre os teores de metais pesados ( $\mathrm{Cd}, \mathrm{Cr}, \mathrm{Cu}, \mathrm{Ni}$ e $\mathrm{Zn}$ ) presentes nas folhas e os teores totais e extraíveis dos mesmos, com o objetivo de verificar efeitos das doses aplicadas. 


\section{RESULTADOS E DISCUSSÂO}

\subsection{Parâmetros de fertilidade do solo}

Os parâmetros de fertilidade do solo e a condutividade elétrica das amostras de terra coletadas, 55 meses após da aplicação do biossólido, mostram variações significativas no valor $\mathrm{pH}$, teores de $\mathrm{P}$ e $\mathrm{Ca}$, acidez potencial $(\mathrm{H}+\mathrm{Al})$ e condutividade elétrica. Já, os valores de carbono orgânico, $\mathrm{K}$ e Mg não foram afetados em função da aplicação do biossólido (Tabela 6 e Apêndice).

$\mathrm{O}$ aumento no valor $\mathrm{pH}$ na camada $0-10 \mathrm{~cm}$ de profundidade foi observado com a aplicação das doses 20 e 40 t ha ${ }^{-1}$ do biossólido. Na demais profundidades estudadas, até $90 \mathrm{~cm}$, não foram observadas alterações significativas nesse parâmetro. Na mesma área experimental 12 meses após a aplicação do biossólido, Andrade (1999) não observou variação no $\mathrm{pH}$ do solo na camada 0-10, mantendo-se os valores $\mathrm{pH}$ entre 3,8 e 4,1 independentemente do tratamento. Esse fenômeno foi atribuído pelo autor ao fato da não incorporação do biossólido no solo dificultando as reações de decomposição do mesmo. Entretanto, Rocha (2002), na mesma área experimental, observou aumento do pH na camada superficial, 32 meses após a adição do biossólido, sendo os valores obtidos de 4.6, 5.8 e 6.1 respectivamente para as doses 10, 20 e $40 \mathrm{t} \mathrm{ha}^{-1}$. Segundo Rocha, a possível causa do tempo demandado para a elevação do pH no solo, apesar da dose aplicada e da natureza permeável do solo, pode ser a demora na solubilização dos constituintes alcalinizantes do material adicionado, devido à não incorporação do biossólido ao solo e à ocorrência de precipitações insuficientes para a mesma. 
Tabela 6 Parâmetros de fertilidade do solo dos tratamentos nas profundidades estudadas. Resultados médios dos quatro blocos avaliados

\begin{tabular}{|c|c|c|c|c|c|c|c|c|c|c|}
\hline Tratam. & Prof. & $\mathrm{pH}$ & C & P-resina & $\mathrm{K}$ & $\mathrm{Ca}$ & $\mathrm{Mg}$ & $\mathrm{H}+\mathrm{Al}$ & $\mathrm{Al}$ & C.E. \\
\hline & $\mathrm{cm}$ & $\mathrm{CaCl}_{2}$ & $\mathrm{~g} \mathrm{dm}^{-3}$ & $\mathrm{mg} \mathrm{dm}^{-3}$ & $-\cdots$ & 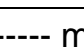 & olc d & $\left.\right|^{-3} \quad-\cdots$ & --- & uS $\mathrm{dm}^{-3}$ \\
\hline \multirow[t]{5}{*}{ C } & $0-10$ & 3,9 & 15,6 & 3,0 & 0,3 & 1,8 & 2,0 & 59,0 & 12,8 & 126,9 \\
\hline & $10-20$ & 4,0 & 9,0 & 2,3 & 0,2 & 2,3 & 2,0 & 43,5 & 10,0 & 79,7 \\
\hline & $20-30$ & 4,1 & 8,1 & 2,5 & 0,1 & 1,8 & 2,0 & 45,5 & 9,0 & 78,1 \\
\hline & $30-60$ & 4,1 & 5,4 & 1,0 & 0,1 & 2,3 & 1,8 & 31,0 & 8,0 & 52,4 \\
\hline & $60-90$ & 4,2 & 4,9 & 1,0 & 0,1 & 2,3 & 2,0 & 25,8 & 6,5 & 58,1 \\
\hline \multirow[t]{5}{*}{ AM } & $0-10$ & 3,8 & 15,3 & 2,3 & 0,4 & 2,0 & 2,0 & 75,3 & 14,0 & 127,4 \\
\hline & $10-20$ & 4,0 & 7,7 & 1,3 & 0,1 & 1,8 & 2,0 & 42,3 & 10,8 & 356,6 \\
\hline & $20-30$ & 4,1 & 7,7 & 1,3 & 0,2 & 2,0 & 2,0 & 43,8 & 9,3 & 80,6 \\
\hline & $30-60$ & 4,1 & 6,7 & 1,0 & 0,1 & 2,0 & 1,8 & 34,8 & 8,5 & 56,6 \\
\hline & $60-90$ & 4,1 & 4,9 & 1,0 & 0,1 & 2,0 & 1,8 & 27,8 & 7,0 & 35,6 \\
\hline \multirow[t]{5}{*}{$10+K$} & $0-10$ & 4,2 & 17,2 & 18,5 & 0,3 & 14,5 & 2,0 & 46,0 & 7,5 & 126,9 \\
\hline & $10-20$ & 4,1 & 8,9 & 8,3 & 0,2 & 7,0 & 2,0 & 41,5 & 8,0 & 105,7 \\
\hline & $20-30$ & 4,1 & 9,0 & 9,3 & 0,1 & 6,8 & 2,0 & 37,3 & 7,5 & 83,3 \\
\hline & $30-60$ & 4,3 & 6,3 & 4,3 & 0,2 & 6,0 & 2,0 & 25,5 & 6,0 & 94,8 \\
\hline & $60-90$ & 4,3 & 5,2 & 1,5 & 0,1 & 5,5 & 2,3 & 25,5 & 5,5 & 45,1 \\
\hline \multirow[t]{5}{*}{$10+K P$} & $0-10$ & 4,2 & 17,3 & 11,0 & 0,3 & 12,8 & 2,0 & 55,0 & 8,8 & 132,4 \\
\hline & $10-20$ & 4,3 & 11,2 & 14,3 & 0,2 & 12,8 & 2,3 & 38,5 & 7,5 & 122,7 \\
\hline & $20-30$ & 4,1 & 8,0 & 1,8 & 0,1 & 5,0 & 1,8 & 39,8 & 8,3 & 84,8 \\
\hline & $30-60$ & 4,1 & 6,1 & 1,3 & 0,1 & 2,8 & 1,8 & 33,8 & 7,8 & 60,6 \\
\hline & $60-90$ & 4,2 & 5,7 & 1,3 & 0,2 & 2,8 & 1,8 & 30,0 & 6,5 & 33,1 \\
\hline \multirow[t]{5}{*}{$20+K$} & $0-10$ & 4,7 & 15,4 & 22,0 & 0,3 & 25,3 & 2,0 & 40,5 & 5,0 & 161,8 \\
\hline & $10-20$ & 4,4 & 10,2 & 8,3 & 0,1 & 9,8 & 2,0 & 40,5 & 6,3 & 103,3 \\
\hline & $20-30$ & 4,3 & 7,7 & 6,8 & 0,1 & 7,3 & 2,0 & 34,8 & 6,5 & 99,5 \\
\hline & $30-60$ & 4,2 & 6,4 & 1,8 & 0,1 & 5,3 & 2,0 & 28,8 & 6,8 & 66,8 \\
\hline & $60-90$ & 4,3 & 5,2 & 1,5 & 0,1 & 4,8 & 2,0 & 26,0 & 5,3 & 52,7 \\
\hline \multirow[t]{5}{*}{$40+K$} & $0-10$ & 6,0 & 15,9 & 290,3 & 0,3 & 52,3 & 2,3 & 14,0 & 0,0 & 321,3 \\
\hline & $10-20$ & 5,3 & 10,3 & 35,8 & 0,2 & 25,5 & 2,0 & 19,0 & 0,8 & 236,4 \\
\hline & $20-30$ & 5,0 & 7,6 & 8,3 & 0,1 & 19,3 & 2,0 & 20,5 & 1,8 & 157,0 \\
\hline & $30-60$ & 4,5 & 5,8 & 4,5 & 0,1 & 9,8 & 2,0 & 22,0 & 4,0 & 103,7 \\
\hline & $60-90$ & 4,7 & 6,6 & 28,3 & 0,1 & 13,0 & 2,0 & 19,5 & 2,8 & 129,9 \\
\hline
\end{tabular}

Tratam. $=$ tratamentos; $\mathrm{C}=$ controle; $\mathrm{AM}=$ adubação mineral; $10+\mathrm{K}=10 \mathrm{t} \mathrm{ha}{ }^{-1}$ de biossólido, complementado com K; $10+\mathrm{KP}=10 \mathrm{t} \mathrm{ha}^{-1}$ de biossólido, complementado com K e P; $20+\mathrm{K}=20 \mathrm{t} \mathrm{ha}^{-1}$ de biossólido, complementado com K; $40+\mathrm{K}=40 \mathrm{t} \mathrm{ha}^{-1}$ de biossólido, complementado com K;

Prof.= profundidade 
Associado ao aumento no pH do solo observou-se a diminuição nos teores de Al trocável e $\mathrm{H}+\mathrm{Al}$ nos tratamentos com o biossólido. O teor de Al foi significativamente diminuído com a aplicação das maiores doses de biossólido (20 e $40 \mathrm{t} \mathrm{ha}^{-1}$ ) na camada 0-10 cm de profundidade. Nas demais profundidades do solo esta diminuição foi observada apenas para o tratamento 40+K. Rocha (2002) observou que, na camada superficial do solo, o teor de Al decresceu ao longo do tempo, principalmente aos 32 meses pós-aplicação do biossólido, e variou entre os tratamentos, sendo menor nos tratamentos que receberam maior dose de biossólido. A elevação do $\mathrm{pH}$ e a precipitação do Al têm sido uma constante em experimentos com o uso de lodo de esgoto onde é feita a adição de cal e pode ser atribuído à alcalinidade do lodo, uma vez que o teor de cal adicionado no condicionamento do lodo de esgoto pode chegar a 35\% em peso do mesmo (Pires, 2003; Bertoncini, 2002; Oliveira et al., 2002; Miki et al., 2001; Anjos \& Mattiazzo, 2000).

Não foram constatadas diferenças significativas entre os tratamentos, ao longo do perfil vertical do solo, para os valores de carbono orgânico. Vaz (2000), na mesma área experimental, observou redução nos teores de MO no solo com a elevação das doses de biossólido, a qual foi atribuída à estimulação que a adição de material orgânico pode exercer sobre a decomposição do húmus, devido ao aumento da atividade microbiana (Stevenson, 1986). Entretanto, esse resultado de Vaz (2000) pode ser questionado tendo em vista como foi feita a determinação do teor de matéria orgânica do solo: oxidação por $\mathrm{K}_{2} \mathrm{Cr}_{2} \mathrm{O}_{7}+\mathrm{H}_{2} \mathrm{SO}_{4}$ a frio e a conversão do teor de carbono obtido para matéria orgânica através do fator 1,72. De acordo com Mattiazzo $\left(2004^{1}\right)$ a utilização do fator 1,72, estabelecido para a conversão de C em MO em solos, não deve ser utilizado para solos tratados com resíduos.

Aos 32 meses pós-aplicação, Rocha (2002), observou variações nos teores de K e Mg do solo que foram atribuídos à mineralização da serapilheira. No presente estudo não foram constatadas diferenças significativas para os valores de $\mathrm{K}$ e $\mathrm{Mg}$ nos diferentes tratamentos nas profundidades estudadas, provavelmente, em função da ciclagem de nutrientes verificada em todos os tratamentos da área experimental.

O teor de fósforo na camada superficial do solo foi alterado pela aplicação do biossólido. Deve ser notado o teor de P na camada de 0-10 cm, de 290,3 mg dm ${ }^{-3}$, que

\footnotetext{
${ }^{1}$ MATTIAZZO, M.E. Comunicação pessoal, 2004.
} 
diferiu significativamente dos demais tratamentos indicando que a totalidade de $P$ contida no biossólido foi transferida para essa camada de solo 55 meses após a aplicação. O tratamento $40+\mathrm{K}$ apresentou, até a profundidade de $20 \mathrm{~cm}$, maior teor de $P$ do que os tratamentos que não receberam a aplicação do biossólido e, embora o teor de $\mathrm{P}$ na camada $10-20 \mathrm{~cm}$ não tenha se mostrado estatisticamente diferente dos apresentados nas demais doses de biossólido, deve-se ressaltar que o valor apresentado, de $35,8 \mathrm{mg} \mathrm{dm}^{-3}$ corresponde a um valor alto de $\mathrm{P}$ enquanto que os demais correspondem a valores baixos do nutriente.

As alterações do teor de $\mathrm{P}$, removido pelo método da resina trocadora de íons, têm sido uma constante nos estudos que foram realizados na área experimental. Vaz (2000), sete meses após aplicação do biossólido, constatou elevação dos teores de P, na camada 0-50 cm do solo, atribuindo esse aumento à mineralização do $P$ contido no biossólido. Quando comparados os valores obtidos no presente estudo com os de Andrade (1999), obtidos 12 meses após a aplicação do biossólido, (de 29,8; 21,0; 17,0; 13,5 e 10,3 $\mathrm{mg} \mathrm{dm}^{-3}$, respectivamente para as profundidades 0-10, 10-20, 20-30, 30-60 e 60-90 cm) pode ser verificar o acúmulo de $P$ nas camadas mais superficiais (0-20 cm), e manutenção do teor nas camadas mais profundas (até $90 \mathrm{~cm}$ ). Aos 32 meses da aplicação do biossólido, Rocha (2002) também observou elevação nos teores de P na camada superficial do solo nos tratamentos que receberam as maiores doses aplicadas.

Outro elemento que apresentou elevação significativa no solo em função das quantidades fornecidas pelo biossólido foi o Ca. Nas maiores doses de biossólido aplicadas (20 e $40 \mathrm{t} \mathrm{ha}^{-1}$ ), na camada 0-10 cm, o teor de Ca passou de 1,8 (tratamento controle) para 25,3 e $52,3 \mathrm{mmol}_{\mathrm{c}} \mathrm{dm}^{-3}$, respectivamente para os tratamentos $20+\mathrm{K}$ e $40+\mathrm{K}$. O teor obtido, no tratamento $40+\mathrm{K}$, foi significativamente maior do que 0 apresentado pelos outros tratamentos que receberam o biossólido. Nesse tratamento, até os $60 \mathrm{~cm}$ de profundidade, a elevação no teor de $\mathrm{Ca}$, foi significativamente diferente dos demais tratamentos com biossólido. Treze meses após a aplicação do biossólido, Vaz (2000) observou elevação no teor de Ca no solo dos tratamentos que receberam o biossólido, sendo essa elevação correlacionada com a maior absorção deste nutriente pelas plantas. A elevação no teor de Ca no solo pela aplicação de biossólidos alcalinos foi também observada por outros autores entre eles Bertoncini (2002) e Oliveira et al. (2002). 
Os valores da condutividade elétrica no tratamento que recebeu a maior quantidade de biossólido (40 t ha-1), após quase cinco anos da aplicação, continuaram significativamente superiores nas camadas 0-10 e 10-20 cm do solo, o que pode ser atribuído à presença e mobilidade de íons, entre eles o $\mathrm{Ca}$, provenientes do biossólido. A partir da camada de $20 \mathrm{~cm}$, a condutividade elétrica do solo não apresentou diferenças significativas, entretanto, apesar da condutividade elétrica medida no tratamento $40+\mathrm{K}$ não ser significativamente diferente da apresentada pelos demais tratamentos, observou-se a tendência de maiores valores nas parcelas com essa dose em todas as profundidades avaliadas o que pode ser indicativo da movimentação de íons no perfil do solo apontando a necessidade de monitoramento das áreas tratadas com o biossólido. Convém, entretanto, salientar que os valores encontrados são todos inferiores àquele que é reportado na literatura como potencialmente causador de problemas de salinidade em solos cultivados (para gramíneas e forrageiras o limite é de $2 \mathrm{dS} \mathrm{m}^{-3}$, enquanto que para soja é de $5 \mathrm{dS} \mathrm{m}^{-3}$, Sparks, 1995). É curioso observar os valores de condutividade elétrica no tratamento com adubação mineral na profundidade de $10-20 \mathrm{~cm}$, reflexo também da movimentação de íons adicionados via fertilizante.

Castro et al. (2002), avaliando num experimento de campo, a capacidade do biossólido como recuperador de áreas degradas, observaram pequenas variações em relação ao pH nos tratamentos com lodo de esgoto, aumento significativo dos teores de cálcio e magnésio em função da utilização de lodo calado e, como conseqüência desse aumento, foram verificadas diferenças nos valores $\mathrm{T}$ e $\mathrm{V} \%$. Os autores observaram teores de fósforo estatisticamente superiores nas parcelas tratadas com lodo de esgoto.

Melo et al. (2000) avaliaram, num experimento de campo em Latossolo Roxo e Latossolo Vermelho-Escuro, o uso de biossólido, proveniente da ETE Barueri, em doses anuais de $10 \mathrm{t} \mathrm{ha}^{-1}$ tendo-se milho como planta teste. Os resultados obtidos mostraram que a aplicação do biossólido por 2 anos consecutivos causou aumento no $\mathrm{pH}$, nos teores de $\mathrm{P}$ e Ca, na capacidade de troca de cátions e na saturação por bases, ao mesmo tempo em que causou diminuição na acidez potencial. Os teores de matéria orgânica e de Mg não foram afetados pelas aplicações sucessivas de biossólido. Os teores de $\mathrm{P}$ tenderam à estabilização no segundo ano o que foi explicado pela menor mineralização do biossólido ou pela maior imobilização do fósforo nesse período 
agrícola. No segundo ano, a aplicação de biossólido causou diminuição na acidez potencial, com tendência de estabilização a partir da dose mais elevada, sendo isto atribuído, principalmente, ao Ca presente em doses elevadas no biossólido. Marques (1997), em solo Latossolo Vermelho-Escuro cultivado com cana-de-açúcar, também encontrou diminuição no teor de $\mathrm{H}+\mathrm{Al}$ como efeito da adição de biossólido, enquanto Berton et al. (1989) encontram diminuição no teor de Al trocável em um Latossolo Vermelho-Amarelo pela adição de biossólido. A saturação por bases foi afetada pela aplicação de biossólido nos dois solos e nos dois anos agrícolas, sendo evidente a grande contribuição dada pelo Ca na saturação por bases. Outra observação que deve ser feita é que, em função do acréscimo de Ca no solo, verificado no presente estudo e que foi proporcionado pelo biossólido tratado com cal, não foram feitos os cálculos correspondentes para obtenção do valor S, CTC e V\% uma vez que os resultados poderiam ser superestimados.

\subsection{Nitrogênio no solo}

Os teores totais de $\mathrm{N}$ presente no solo não diferiram entre os tratamentos testados, após 55 meses da aplicação do biossólido ou de fertilizantes minerais, até profundidade de $60 \mathrm{~cm}$ do solo. Já na última camada do solo estudada (60-90 cm de profundidade), os teores de $\mathrm{N}$-total nos tratamentos que receberam as maiores quantidades de biossólido (20 e $40 \mathrm{t} \mathrm{ha}^{-1}$ ) mostraram-se superiores aos registrados no tratamento controle, sendo isto indicativo da ocorrência de percolação de $\mathrm{N}$ ao longo do perfil do solo. Não obstante, estes valores não foram diferentes dos observados na parcela tratada com fertilizante mineral. Os teores médios apresentados foram iguais a 0,$61 ; 0,41 ; 0,37 ; 0,30$ e $0,28 \mathrm{~g} \mathrm{~kg}^{-1}$, respectivamente para as profundidades de $0-10$; 10-20; 20-30; 30-60 e 60-90 cm. (Tabela 7).

Andrade \& Mattiazzo (2000), avaliando o teor total de $\mathrm{N}$ no solo na mesma área experimental, levando em consideração apenas os tratamentos C, 10+K, 20+K e 40+K, doze meses após a aplicação do biossólido, encontraram teores médios, nas camadas 0-10, 10-20, 20-30, 30-60 e 60-90 cm, respectivamente de 0,64;0,47;0,41;0,38 e 0,31 $\mathrm{g} \mathrm{kg}^{-1}$. Comparando esses teores aos obtidos no presente estudo para os mesmos tratamentos ( $\mathrm{C}, 10+\mathrm{K}, 20+\mathrm{K}$ e $40+\mathrm{K})$, que foram, em média, 0,62;0,39;0,38; 0,29; e, $0,27 \mathrm{~g} \mathrm{~kg}^{-1}$ para as camadas $0-10,10-20,20-30,30-60$ e 60-90, respectivamente 
(valores elaborados a partir dos dados da Tabela 7), nota-se que são de mesma magnitude. Desse modo, pode-se inferir que o teor total de $\mathrm{N}$ tem se mantido estável no tempo, o que pode ser explicado por vários fatores entre eles a existência de compostos nitrogenados de baixa taxa de mineralização nos biossólidos (Soares, 2003), e a imobilização e/ou incorporação da fração residual do N contido no biossólido em formas mais resistentes à biodegradação (Boeira et al., 2003; Ryan et al., 1973).

Tabela 7 Teor total de $\mathrm{N}$ no solo. Resultados expressos como média dos quatro blocos avaliados

\begin{tabular}{|c|c|c|c|c|c|}
\hline \multirow[t]{2}{*}{ Tratamento } & \multicolumn{5}{|c|}{ Profundidades $(\mathrm{cm})$} \\
\hline & $0-10$ & $10-20$ & $20-30$ & $30-60$ & $60-90$ \\
\hline & ----------- & . & $-\mathrm{g} \mathrm{kg}^{-1}$ & 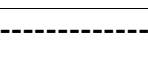 & ------ \\
\hline $\mathrm{C}$ & $0,58 a b^{(1)}$ & $0,38 a$ & $0,31 \mathrm{a}$ & $0,25 a$ & $0,22 b$ \\
\hline AM & $0,60 a b$ & $0,45 a$ & $0,34 a$ & $0,34 a$ & $0,24 a b$ \\
\hline $10+K$ & $0,62 a b$ & $0,40 a$ & $0,50 a$ & $0,27 \mathrm{a}$ & $0,26 a b$ \\
\hline $10+K P$ & $0,56 \mathrm{~b}$ & $0,46 a$ & $0,32 \mathrm{a}$ & $0,30 \mathrm{a}$ & $0,31 a b$ \\
\hline $20+K$ & $0,59 a b$ & $0,38 a$ & $0,38 a$ & $0,33 \mathrm{a}$ & $0,33 \mathrm{a}$ \\
\hline $40+K$ & $0,70 \mathrm{a}$ & $0,41 \mathrm{a}$ & $0,34 \mathrm{a}$ & $0,31 \mathrm{a}$ & $0,31 \mathrm{a}$ \\
\hline Média & 0,61 & 0,41 & 0,37 & 0,30 & 0,28 \\
\hline C.V. $\%$ & 14,12 & 24,32 & 40,67 & 27,45 & 28,24 \\
\hline
\end{tabular}

Os resultados obtidos Oliveira et al. (2001) e Franco et al. (2003) mostram aumento dos teores de $\mathrm{N}$ total nas camadas mais superficiais de solos tratados com biossólidos, porém nesses estudos o resíduo foi incorporado ao solo em doses mais elevadas (até $300 \mathrm{t} \mathrm{ha}^{-1}$ ). Em solo sob eucalipto e após 12 meses da aplicação de doses de biossólido até $40 \mathrm{t} \mathrm{ha}^{-1}$, sem posterior incorporação, no sistema de cultivo mínimo, Soares (2003) observou redução da concentração de $N$ total no solo.

Os resultados de $\mathrm{N}$-inorgânico, apresentados na Tabela 8, indicam que não houve movimentação de nitratos no perfil do solo de forma a causar preocupação quanto a contaminação do lençol freático. Deve-se considerar, porém, que os valores de desvio padrão foram elevados, ao contrário do verificado nas determinações de N-total, o que 
deve ter colaborado para que não fossem observadas diferenças significativas entre tratamentos.

Tabela 8 Teor de N-inorgânico no solo. Resultados expressos como média dos quatro blocos avaliados

\begin{tabular}{|c|c|c|c|c|c|}
\hline \multirow[t]{2}{*}{ Tratamento } & \multicolumn{5}{|c|}{ Profundidades $(\mathrm{cm})$} \\
\hline & $0-10$ & $10-20$ & $20-30$ & $30-60$ & $60-90$ \\
\hline & \multicolumn{5}{|c|}{--------------------------------- mg kg'1 ------------------------------- } \\
\hline $\mathrm{C}$ & $7,3 \mathrm{a}^{(1)}$ & $5,5 \mathrm{a}$ & $3,5 \mathrm{a}$ & 3,0 a & $2,2 \mathrm{a}$ \\
\hline AM & 8,4 a & 5,9 a & $6,0 \mathrm{a}$ & 1,2 a & $2,2 \mathrm{a}$ \\
\hline $10+K$ & $8,5 \mathrm{a}$ & $6,4 \mathrm{a}$ & $6,1 \mathrm{a}$ & 5,3 a & 6,0 a \\
\hline $10+K P$ & 8,8 a & 8,0 a & $6,7 \mathrm{a}$ & 1,6 a & 2,6 a \\
\hline $20+K$ & $12,7 \mathrm{a}$ & 3,9 a & $2,4 \quad a$ & $2,2 \mathrm{a}$ & 5,7 a \\
\hline $40+K$ & $8,4 \mathrm{a}$ & 2,1 a & $3,8 \mathrm{a}$ & $1,5 \mathrm{a}$ & $0,6 \mathrm{a}$ \\
\hline Média & 9,0 & 5,3 & 4,8 & 2,5 & 3,2 \\
\hline C.V. \% & 47,18 & 84,38 & 61,06 & 115,14 & 97,81 \\
\hline
\end{tabular}

Andrade \& Mattiazzo (2000) encontraram, aos doze meses da aplicação do biossólido, teores médios de N-inorgânico superiores, 63 a 91 \%, aos apresentados na Tabela 8 (quando comparados com os mesmos tratamentos utilizados para Andrade \& Mattiazzo, ou seja, C, $10+K, 20+K$ e 40+K), o que indica a presença de formas passíveis de lixiviação em maior quantidade até um ano após a aplicação do biossólido. As diferenças constatadas podem estar relacionadas ao estágio avançado de desenvolvimento das árvores que implica no aumento na absorção e assimilação de $\mathrm{N}$ por parte dos eucaliptos, refletido no maior crescimento das árvores (Rocha, 2002; Vaz, 2000) e na maior concentração de $\mathrm{N}$ nas folhas.

Souza et al. (2003), não observaram acúmulo de N-inorgânico no perfil de um Latossolo irrigado com efluente de esgoto, permanecendo o líquido percolado ao longo do perfil, com teores abaixo do limite máximo de nitrito e nitrato recomendado para água para consumo humano segundo a Portaria 1469/2000 do Ministério da Saúde (BRASIL, 2000). 
Aumento dos teores de N-inorgânico após adição de biossólidos tem sido freqüentemente encontrado na literatura, inclusive em profundidade no solo, o que é indicativo de lixiviação do nutriente (Luo et al., 2003; Vega et al., 2003; Oliveira et al., 2001). Novamente há que se destacar o papel da incorporação do resíduo ao solo nesses trabalhos, que deve aumentar a taxa de mineralização do N-orgânico e, conseqüentemente, a disponibilização de N-inorgânico, permitindo excesso de $\mathrm{N}$-inorgánico que fica passível de lixiviação no perfil do solo se não houver sincronia com a absorção pelas plantas.

\subsection{Nitrogênio nas folhas}

A concentração de $\mathrm{N}$ nas folhas de eucalipto não foi influenciada pelas doses de biossólido, 55 meses após a aplicação (Tabela 9). A concentração média de $\mathrm{N}$ nas folhas, considerando todos os tratamentos, foi igual a $23,14 \mathrm{~g} \mathrm{~kg}^{-1}$, superior ao que é considerado adequado para o eucalipto, entre 13 e $18 \mathrm{~g} \mathrm{~kg}^{-1}$ (Gonçalves et al., 1997). Convêm, entretanto, observar as maiores concentrações de $\mathrm{N}$ nas plantas tratadas com as maiores doses do biossólido.

Tabela 9 Concentração de $\mathrm{N}$ nas folhas. Resultados expressos como média dos quatro blocos avaliados

\begin{tabular}{cc}
\hline Tratamento & $\mathrm{g} \mathrm{kg}^{-1}$ \\
\hline $\mathrm{C}$ & $22,63 \mathrm{a}^{(1)}$ \\
$\mathrm{AM}$ & $22,13 \mathrm{a}$ \\
$10+\mathrm{K}$ & $20,63 \mathrm{a}$ \\
$10+\mathrm{KP}$ & $22,86 \mathrm{a}$ \\
$20+\mathrm{K}$ & $25,85 \mathrm{a}$ \\
$40+\mathrm{K}$ & $24,76 \mathrm{a}$ \\
\hline Media & 23,14 \\
$\mathrm{C} . \mathrm{V} . \%$ & 10,91 \\
\hline (1) médias seguidas da mesma letra não diferem entre si pelo teste de \\
Tukey (nível 5\% de significância)
\end{tabular}


Na mesma área experimental, aos 12 (Andrade, 1999), 16 (Guedes, 2000) e 36 meses (Rocha, 2002) da aplicação do biossólido, foram observados efeitos significativos das doses de biossólido na concentração foliar de N. Aos 12 (Andrade, 1999) e 16 meses (Guedes, 2000) foi observada correlação positiva entre dose de biossólido e concentração de $\mathrm{N}$ na folha, enquanto que aos 36 meses tal correlação não foi significativa. A ausência de efeito das doses de biossólido na concentração foliar de $\mathrm{N}$ encontrada no presente estudo pode ser explicada pela própria fisiologia do eucalipto, o qual possui um estádio inicial de formação da copa, na qual a demanda de $\mathrm{N}$ é muito elevada (Gonçalves et al., 2000); após o fechamento das copas fatores como luz e água passam a ser mais limitantes para o desenvolvimento das árvores e à própria reciclagem bioquímica de $\mathrm{N}$ passa a suprir a maior parte da demanda da planta por esse nutriente. (Rocha, 2002). Mesmo 12 meses após aplicação do biossólido, o aumento da concentração foliar de $\mathrm{N}$ não foi atribuído inteiramente ao $\mathrm{N}$ mineralizado do biossólido, sendo destacada a provável participação do $\mathrm{N}$ mineralizado do solo (Andrade, 1999), em função de melhorias das condições para a atividade microbiana.

Soares (2003), 12 meses após a aplicação de biossólido numa plantação de eucalipto, em sistema de cultivo mínimo, observou diminuição nas concentrações foliares de $\mathrm{N}$, porém sem verificar relação com as doses do resíduo. Apesar da diminuição, as concentrações foliares de $\mathrm{N}$ ficaram acima do adequado em todos os períodos estudados, sendo isto atribuído pela autora à contribuição da serapilheira e da matéria orgânica na disponibilização de $\mathrm{N}$ às plantas.

\subsection{Correlação solo-folha dos teores de nitrogênio}

Os teores totais e inorgânicos de N no solo, camadas 0-10-, 10-20, 20-30, 30-60 e 60-90 cm, não foram correlacionados significativamente com a concentração do elemento nas folhas, 55 meses após aplicação do biossólido (Tabela 10). Este resultado pode ser explicado pela eficiência de reciclagem bioquímica do $\mathrm{N}$ pelo eucalipto, que com o passar do tempo diminui a demanda por este nutriente do solo. 
Tabela 10 Coeficientes de correlação entre concentração foliar de $\mathrm{N}$ e teor total e inorgânico de N no solo

\begin{tabular}{ccc}
\hline Profundidade $(\mathrm{cm})$ & $\mathrm{r}^{2}(\mathrm{~N}$-total/N-folha) & $\mathrm{r}^{2}(\mathrm{~N}$-inorgânico/N-folha $)$ \\
\hline $0-10$ & 0,03 & $-0,09$ \\
$10-20$ & $-0,12$ & $-0,26$ \\
$20-30$ & $-0,14$ & $-0,36$ \\
$30-60$ & 0,18 & $-0,31$ \\
$60-90$ & 0,10 & $-0,12$ \\
\hline
\end{tabular}

\subsection{Teor total e extraível dos metais $\mathrm{Cd}, \mathrm{Cu}, \mathrm{Cr}$, Ni e $\mathrm{Zn}$ no solo}

Os teores de Cd total e extraível (com Mehlich 3), no extrato para análise, estiveram abaixo do limite de detecção do espectrofotômetro de absorção atômica (AA), o que indica, não a ausência do elemento, mas sim de concentrações inferiores a $0,006 \mathrm{mg} \mathrm{ml}^{-1}$ de extrato, que correspondeu a $0,6 \mathrm{mg} \mathrm{kg}^{-1}$ de terra. $\mathrm{O}$ mesmo foi observado por Andrade \& Mattiazzo (2000) na mesma área experimental doze meses após aplicação de biossólido. Camargo et al. (2003), após a aplicação de lodo de esgoto, em dose total de até $80 \mathrm{Mg} \mathrm{ha}^{-1}$, durante quatro anos, também não conseguiram detectar Cd extraível (com DTPA e Mehlich 3) nas amostras de terra.

Não foram observadas diferenças significativas nos teores de Cr-total entre os tratamentos avaliados, independente da profundidade (Tabela 11). Andrade \& Mattiazzo (2000), doze meses após aplicação do biossólido, obtiveram teores médios de Cr-total, para os tratamentos C, 10+K, 20+K e 40+K, iguais a 13,2, 13,6, 14,7, 15,9 e $16,7 \mathrm{mg} \mathrm{kg}^{-1}$, respectivamente para as camadas 0-10, 10-20, 20-30, 30-60 e 60-90 $\mathrm{cm}$ de profundidade. Após 55 meses após aplicação do biossólido, nos mesmos tratamentos utilizados por Andrade \& Mattiazzo (C, 10+K, 20+K e 40+K), os teores totais de $\mathrm{Cr}$ resultaram da mesma magnitude daqueles observados 12 meses depois da aplicação. 
Tabela 11 Teor total de $\mathrm{Cr}$ no solo. Resultados expressos como média dos quatro blocos avaliados

\begin{tabular}{|c|c|c|c|c|c|}
\hline \multirow[t]{2}{*}{ Tratamento } & \multicolumn{5}{|c|}{ Profundidades $(\mathrm{cm})$} \\
\hline & $0-10$ & $10-20$ & $20-30$ & $30-60$ & $60-90$ \\
\hline & ----- & ---------- & $\mathrm{mg} \mathrm{kg}^{-1}$ & ---------- & ------ \\
\hline $\mathrm{C}$ & $12,21 \mathrm{a}^{(1)}$ & $11,40 \mathrm{a}$ & $10,87 \mathrm{a}$ & $13,39 a$ & $11,41 \mathrm{a}$ \\
\hline AM & $11,40 \mathrm{a}$ & $10,85 a$ & $11,51 \mathrm{a}$ & $12,58 \mathrm{a}$ & $13,59 \mathrm{a}$ \\
\hline $10+K$ & $14,16 \mathrm{a}$ & $10,47 \mathrm{a}$ & $10,63 \mathrm{a}$ & $10,60 \mathrm{a}$ & $13,62 \mathrm{a}$ \\
\hline $10+K P$ & $12,94 \mathrm{a}$ & $12,38 \mathrm{a}$ & $10,18 \mathrm{a}$ & $14,37 \mathrm{a}$ & $12,06 \mathrm{a}$ \\
\hline $20+K$ & $18,66 \mathrm{a}$ & $14,24 \mathrm{a}$ & $12,10 \mathrm{a}$ & $13,39 a$ & $15,93 \mathrm{a}$ \\
\hline $40+K$ & $18,29 \mathrm{a}$ & $14,55 \mathrm{a}$ & $16,46 \mathrm{a}$ & $14,65 \mathrm{a}$ & $13,11 \mathrm{a}$ \\
\hline Media & 14,61 & 12,32 & 11,96 & 13,16 & 13,29 \\
\hline C.V. \% & 31,13 & 28,00 & 39,64 & 39,87 & 36,30 \\
\hline
\end{tabular}

Os teores de Cr extraídos das amostras de terra, usando Mehlich 3 como extrator estiveram abaixo do limite de detecção pelo método analítico utilizado (AA). Desse modo, pode-se afirmar que se Cr está presente nas amostras na forma extraível, encontra-se em concentrações analíticas inferiores a 0,05 $\mu \mathrm{g} \mathrm{ml}^{-1}$ de extrato, ou 0,5 mg $\mathrm{kg}^{-1}$ de terra. Aos doze meses da aplicação do biossólido os teores de Cr-extraíveis (com Mehlich 3) observados por Andrade \& Mattiazzo (2000) também resultaram inferiores ao limite de detecção do AA utilizado.

O teor total de Cu no solo, somente apresentou diferença entre os tratamentos na camada 0-10 cm de profundidade (Tabela 12), sendo que o teor de Cu-total observado no tratamento $40+\mathrm{K}$ foi superior ao dos tratamentos C e AM. Os valores apresentados na Tabela 12 são, em média, inferiores aos apresentados por Andrade \& Mattiazzo (2000), que não observaram efeito das doses de biossólido no teor total de Cu no solo, após doze meses da aplicação, atribuindo o fato ao modo de aplicação do biossólido no ensaio (em superfície sem posterior incorporação ao solo), o que não favoreceu a decomposição do material devido à limitada superfície de contacto biossólido-solo. 
Tabela 12 Teor total de Cu no solo. Resultados expressos como média dos quatro blocos avaliados

\begin{tabular}{|c|c|c|c|c|c|c|}
\hline \multirow[t]{2}{*}{ Tratamento } & \multicolumn{6}{|c|}{ Profundidades $(\mathrm{cm})$} \\
\hline & $0-10$ & $10-20$ & & $20-30$ & $30-60$ & $60-90$ \\
\hline & \multicolumn{6}{|c|}{ 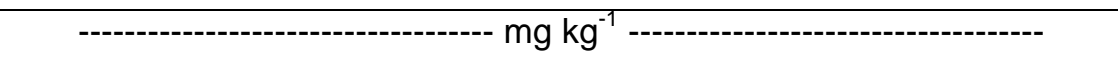 } \\
\hline $\mathrm{C}$ & $9,96 b^{(1)}$ & 10,67 & a & 9,91 a & 11,17 a & 11,66 a \\
\hline AM & $8,91 \mathrm{~b}$ & 8,63 & a & 8,50 a & 9,38 a & 10,88 a \\
\hline $10+K$ & $10,92 a b$ & 9,73 & a & 8,90 a & 9,63 a & 10,65 a \\
\hline $10+K P$ & $11,19 a b$ & 11,39 & a & $9,68 \quad a$ & $10,65 \mathrm{a}$ & $11,33 \mathrm{a}$ \\
\hline $20+K$ & $11,41 a b$ & 11,30 & a & 10,87 a & $13,64 a$ & $10,46 \mathrm{a}$ \\
\hline $40+K$ & $15,28 \mathrm{a}$ & 11,59 & $\mathrm{a}$ & $10,00 \quad a$ & $10,19 a$ & $11,13 \mathrm{a}$ \\
\hline Media & 11,28 & 10,55 & & 9,64 & 10,78 & 11,02 \\
\hline C.V. \% & 17,46 & 17,34 & & 15,53 & 28,83 & 12,34 \\
\hline
\end{tabular}

As concentrações no solo de Cu-extraível por Mehlich 3 tenderam a ser maiores, até $60 \mathrm{~cm}$ de profundidade, nos tratamentos que receberam biossólido (Tabela 13). $\mathrm{Na}$ camada 0-10 cm, os tratamentos $20+\mathrm{K}$ e 40+K exibiram teores do metal superiores aos teores encontrados no C e AM, não diferindo dos tratamentos com dose $10 \mathrm{t} \mathrm{ha}^{-1} \mathrm{de}$ biossólido. Nas profundidades 10-20, 20-30 e 30-60 cm houve destaque para 0 tratamento com a maior quantidade de biossólido $(40+K)$, cujo teor médio foi sempre superior aos determinados no $\mathrm{C}$ e no AM. Não houve diferença entre os tratamentos quanto ao teor de Cu-extraível na camada 60-90 cm de profundidade.

De acordo com Andrade \& Mattiazzo (2000), o efeito significativo das doses de biossólido sobre o teor de Cu extraível por Mehlich 3, doze meses após a aplicação, foi observado apenas na camada 0-10 cm, sendo atribuído à baixa à decomposição do biossólido associada à baixa movimentação desse metal liberado e à tendência deste metal em formar complexos estáveis com ligantes orgânicos (Landonin \& Margolina, 1997; Melo et al., 1997 ; Hughes, 1981).

Galdos et al. (2003), depois da incorporação de lodo de esgoto num Latossolo Vermelho eutrófico, textura argilosa, não observaram aumento significativo no teor extraível de Cu na profundidade do solo. Já, Camargo et al. (2003), em experimento com aplicação de lodo de esgoto durante quatro anos, observaram que as quantidades 
extraíveis de Cu (DTPA e Mehlich 3) aumentaram linearmente com a aplicação do lodo.

Tabela 13 Teor de Cu-extraível no solo. Resultados expressos como média dos quatro blocos avaliados

\begin{tabular}{|c|c|c|c|c|c|}
\hline \multirow[t]{2}{*}{ Tratamento } & \multicolumn{5}{|c|}{ Profundidades (cm) } \\
\hline & $0-10$ & $10-20$ & $20-30$ & $30-60$ & $60-90$ \\
\hline & \multicolumn{5}{|c|}{ 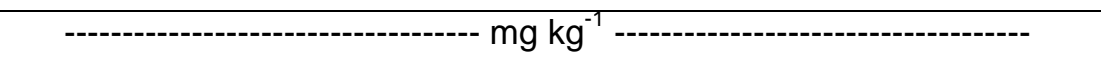 } \\
\hline $\mathrm{C}$ & $0,28 c^{(1)}$ & $0,33 \mathrm{~b}$ & $0,40 \mathrm{~b}$ & $0,33 \mathrm{~b}$ & $0,43 \mathrm{a}$ \\
\hline AM & $0,25 \mathrm{c}$ & $0,33 \mathrm{~b}$ & $0,40 \mathrm{~b}$ & $0,33 \mathrm{~b}$ & $0,43 a$ \\
\hline $10+K$ & $0,60 \mathrm{bc}$ & $0,53 \mathrm{~b}$ & $0,53 a b$ & $0,50 a b$ & $0,53 \mathrm{a}$ \\
\hline $10+K P$ & 0,58 bc & $0,68 \mathrm{~b}$ & $0,53 a b$ & $0,38 a b$ & 0,45 a \\
\hline $20+K$ & $0,90 \mathrm{~b}$ & $0,68 \mathrm{~b}$ & $0,50 \mathrm{~b}$ & $0,40 a b$ & $0,45 \mathrm{a}$ \\
\hline $40+K$ & $2,18 \mathrm{a}$ & $1,18 \mathrm{a}$ & 0,78 a & $0,60 \mathrm{a}$ & $0,50 \mathrm{a}$ \\
\hline Media & 0,80 & 0,62 & 0,52 & 0,42 & 0,46 \\
\hline C.V. \% & 31,81 & 34,90 & 22,42 & 24,38 & 23,55 \\
\hline
\end{tabular}

Calculando os teores de Cu-extraível (Tabela 13) em relação ao teor total desse metal (Tabela 12), vê-se que houve aumento da porcentagem de formas extraíveis com a aplicação das doses de biossólidos até a profundidade de $60 \mathrm{~cm}: 2,8 \%$ no controle, 5,3\% na dose $10 \mathrm{t} \mathrm{ha}^{-1}$ de biossólido e 14,25\% na dose 40 t ha ${ }^{-1}$ de biossólido. Considerando que os teores totais do metal nas profundidades abaixo de $10 \mathrm{~cm}$ não foram afetados pela aplicação de biossólido, pode-se sugerir que a adição do resíduo modificou a dinâmica das formas inorgânicas e orgânicas de Cu no solo. Ao comparar as porcentagens de Cu-extraível, aos 12 (Andrade \& Mattiazzo, 2000) e aos 55 meses, observa-se uma redução no teor apresentado superior a $50 \%$ em todas as profundidades com o tempo decorrido entre as duas avaliações, o que pode estar relacionada à absorção e imobilização do metal na massa vegetal do eucalipto.

O comportamento verificado para o Cu-extraível, no presente estudo, evidencia lixiviação desse metal até $60 \mathrm{~cm}$ de profundidade, e contraria a observação de que $\mathrm{Cu}$ é um elemento de baixa mobilidade no perfil do solo (Rodella, 1993). Tendo em vista a forma com que o elemento se apresenta predominantemente no biossólido, 74,5\%, 
ligado a fração orgânica, de acordo com Bertoncini (2002), pode-se supor que houve mineralização dessa fração orgânica contendo Cu com a conseqüente disponibilização do elemento para o meio.

Com relação ao teor total do metal $\mathrm{Ni}$ no solo, não foram verificadas diferenças devidas à aplicação do biossólido. Os teores médios de Ni apresentados, 55 meses após aplicação do biossólido, variaram de 3,73 a 0,97 mg kg-1, respectivamente para as camadas de 0-10 e 60-90 cm de profundidade (Tabela 14). Aos doze meses da aplicação do biossólido, os teores totais de Ni foram menores que $8 \mathrm{mg} \mathrm{kg}^{-1}$ de terra, valor esse correspondente ao limite de detecção do método analítico utilizado na ocasião (Andrade \& Mattiazzo, 2000). O que num primeiro momento poderia sugerir diminuição no teor de Ni no solo, na realidade evidencia avanço na sensibilidade do método analítico para determinação do metal.

Tabela 14 Teor total de Ni no solo. Resultados expressos como média dos quatro blocos avaliados

\begin{tabular}{|c|c|c|c|c|c|}
\hline \multirow[t]{2}{*}{ Tratamento } & \multicolumn{5}{|c|}{ Profundidades $(\mathrm{cm})$} \\
\hline & $0-10$ & $10-20$ & $20-30$ & $30-60$ & $60-90$ \\
\hline & ---------- & ------------- & $-\mathrm{mg} \mathrm{kg}^{-1}$ & --------------- & --------- \\
\hline C & $2,48 \mathrm{a}^{(1)}$ & $1,73 \mathrm{a}$ & $1,75 \mathrm{a}$ & $1,23 \mathrm{a}$ & $1,23 a$ \\
\hline AM & 2,46 a & $2,20 a$ & 2,26 a & 1,23 a & $0,98 a$ \\
\hline $10+K$ & 5,22 a & 3,25 a & 2,21 a & $1,96 \mathrm{a}$ & $1,48 a$ \\
\hline $10+K P$ & $3,23 a$ & 3,46 a & 4,77 a & 3,48 a & $0,65 a$ \\
\hline $20+K$ & $3,93 a$ & $2,21 \mathrm{a}$ & 3,21 a & $1,48 \quad a$ & $1,00 \mathrm{a}$ \\
\hline $40+K$ & 5,02 a & 2,71 a & 1,74 a & $1,24 a$ & $0,49 a$ \\
\hline Média & 3,73 & 2,59 & 2,66 & 1,77 & 0,97 \\
\hline C.V. \% & 51,57 & 83,91 & 86,32 & 109,70 & 111,22 \\
\hline
\end{tabular}

Os teores de Ni-extraível, da camada $0-10 \mathrm{~cm}$ de profundidade, foram influenciados pelos tratamentos, sendo de 6 a 23 vezes maiores nas parcelas que receberam biossólido em comparação com os tratamentos C e AM (Tabela 15). Abaixo de $10 \mathrm{~cm}$ de profundidade, o efeito do biossólido no teor extraível de Ni não foi evidente, embora 
até $60 \mathrm{~cm}$ possa ser observada tendência de aumento das concentrações médias de Ni-extraível, principalmente nos tratamentos com $10 \mathrm{t} \mathrm{ha}^{-1}$ de biossólido.

Camargo et al. (2003), após aplicação de biossólido durante quatro anos, em doses totais de até $80 \mathrm{Mg} \mathrm{ha}^{-1}$, também observaram aumentos lineares nas quantidades de Ni-extraível (DTPA e Mehlich 3) em função da aplicação do resíduo.

Tabela 15 Teor de Ni-extraível no solo. Resultados expressos como média dos quatro blocos avaliados

\begin{tabular}{cccccc}
\hline Tratamento & \multicolumn{5}{c}{ Profundidades (cm) } \\
& $0-10$ & $10-20$ & $20-30$ & $30-60$ & $60-90$ \\
\hline C & $0,06 \mathrm{~b}^{(1)}$ & $0,13 \mathrm{a}$ & $0,21 \mathrm{~b}$ & $0,13 \mathrm{~b}$ & $0,13 \mathrm{a}$ \\
AM & $0,04 \mathrm{~b}$ & $0,21 \mathrm{a}$ & $0,15 \mathrm{~b}$ & $0,25 \mathrm{~b}$ & $0,30 \mathrm{a}$ \\
$10+\mathrm{K}$ & $0,53 \mathrm{ab}$ & $0,30 \mathrm{a}$ & $0,83 \mathrm{a}$ & $0,85 \mathrm{a}$ & $0,39 \mathrm{a}$ \\
$10+\mathrm{KP}$ & $0,26 \mathrm{~b}$ & $0,41 \mathrm{a}$ & $0,53 \mathrm{ab}$ & $0,40 \mathrm{ab}$ & $0,20 \mathrm{a}$ \\
$20+\mathrm{K}$ & $0,56 \mathrm{ab}$ & $0,49 \mathrm{a}$ & $0,53 \mathrm{ab}$ & $0,29 \mathrm{~b}$ & $0,34 \mathrm{a}$ \\
$40+\mathrm{K}$ & $0,93 \mathrm{a}$ & $0,65 \mathrm{a}$ & $0,40 \mathrm{~b}$ & $0,09 \mathrm{~b}$ & $0,51 \mathrm{a}$ \\
Media & 0,40 & 0,63 & 0,44 & 0,33 & 0,31 \\
C.V. \% & 68,48 & 84,51 & 42,00 & 61,09 & 84,30
\end{tabular}

${ }^{(1)}$ médias seguidas da mesma letra, na coluna, não diferem entre si pelo teste de Tukey (nível 5\% de significância)

Conforme verificado para o Cu, o Ni-extraível, expresso como porcentagem do total de Ni no solo, também aumentou com a adição de biossólido. Mesmo na profundidade 10-20 cm, cujos teores totais (Tabela 14) e extraíveis (Tabela 15) não diferiram entre os tratamentos, foi observado aumento da porcentagem relativa de Ni-extraível, indicando alteração da dinâmica entre formas orgânicas e inorgânicas de Ni no solo derivado da aplicação de biossólido.

Uma vez que no biossólido a distribuição do Ni esteve entre as frações orgânicas (32,6\%), óxidos (22,8\%), residual (19,6\%) e carbonatada (17,9\%) (Bertoncini, 2002), pode-se supor que, assim como sugerido para o $\mathrm{Cu}$, houve mineralização das formas orgânicas, às quais o Ni estava associado, e/ou solubilização do carbonato de forma a passar o metal para uma forma mais móvel permitindo a sua movimentação no perfil do solo. Em função destes resultados, pode-se inferir que existem evidências para se 
supor a movimentação do $\mathrm{Ni}$ até $60 \mathrm{~cm}$ de profundidade e que esta movimentação no perfil do solo foi dependente da dose de biossólido aplicada. $\mathrm{O} \mathrm{pH}$ mais alto verificado no tratamento $40+\mathrm{K}$ não impediu as transformações que ocorreram com o elemento.

$\mathrm{Na}$ Tabela 16 pode ser observando teor total de $\mathrm{Zn}$ no solo para o tratamento que tratamento que recebeu $40 \mathrm{t} \mathrm{ha}^{-1}$ de biossólido, na camada 0-10 cm, em comparação aos demais tratamentos avaliados, o que pode ser atribuído à quantidade fornecida pelo biossólido. Verifica-se também nessa tabela a relação positiva entre os teores totais do metal e a dose de biossólido aplicada (17,12; 26,54; e 47,63 mg kg-1 de Zn, nos tratamentos $10+\mathrm{K}, 20+\mathrm{K}$ e $40+\mathrm{K}$, respectivamente).

Tabela 16 Teor total de Zn no solo. Resultados expressos como média dos quatro blocos avaliados

\begin{tabular}{|c|c|c|c|c|c|}
\hline \multirow[t]{2}{*}{ Tratamento } & \multicolumn{5}{|c|}{ Profundidades $(\mathrm{cm})$} \\
\hline & $0-10$ & $10-20$ & $20-30$ & $30-60$ & $60-90$ \\
\hline & \multicolumn{5}{|c|}{ 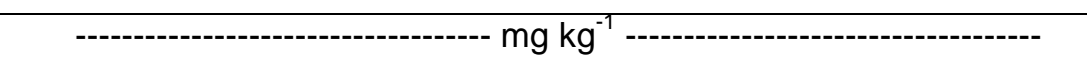 } \\
\hline $\mathrm{C}$ & $12,16 b^{(1)}$ & 16,30 c & $14,50 \mathrm{ab}$ & $13,08 a b$ & $10,62 a$ \\
\hline AM & $8,37 \mathrm{~b}$ & 11,05 a & $11,25 \mathrm{~b}$ & $9,29 \mathrm{~b}$ & $10,81 \mathrm{a}$ \\
\hline $10+K$ & $17,12 \mathrm{~b}$ & 14,49 & $12,09 \mathrm{~b}$ & $13,52 a b$ & $12,35 \mathrm{a}$ \\
\hline $10+K P$ & $19,15 \mathrm{~b}$ & 22,24 a & $16,35 a b$ & $17,30 \mathrm{ab}$ & 13,75 a \\
\hline $20+K$ & $26,54 \mathrm{~b}$ & 20,80 & $22,94 \mathrm{a}$ & 23,79 a & $17,69 \mathrm{a}$ \\
\hline $40+K$ & $47,63 \mathrm{a}$ & 26,82 & $18,75 \mathrm{ab}$ & $18,11 \mathrm{ab}$ & 15,79 a \\
\hline Media & 21,83 & 19,62 & 15,98 & 15,85 & 13,50 \\
\hline C.V. $\%$ & 41,48 & 46,89 & 28,42 & 35,23 & 32,83 \\
\hline
\end{tabular}

(1) médias seguidas da mesma letra, na coluna, não diferem entre si pelo teste de Tukey (nível 5\% de significância)

O aumento do teor total de Zn no solo já havia sido destacado por Andrade \& Mattiazzo (2000) 12 meses após a aplicação do biossólido. A manutenção do maior teor de $\mathrm{Zn}$ na camada $0-10 \mathrm{~cm}$ do solo do tratamento $40+\mathrm{K}$, durante todo o período, pode ser explicada pela ciclagem do nutriente proveniente da deposição de folhas, que foi maior nesse tratamento (Guedes, 2000; Guedes²), e também pelo aporte direto de Zn via biossólido e que ainda não foi totalmente solubilizado. Isso faz presumir que o

${ }^{2}$ GUEDES, M.C. Comunicação pessoal, 2004. 
Zn acumulado esteja, prioritariamente, associado à fração carbonato, como verificado por Bertoncini (2002), um ano após a aplicação de biossólido alcalino no solo.

$\mathrm{Na}$ camada de $10-20 \mathrm{~cm}$ do solo, os teores totais de $\mathrm{Zn}$ nos tratamentos não diferiram entre si. Nas camadas $20-30$ e $30-60 \mathrm{~cm}$ de profundidade, o tratamento $20+\mathrm{K}$ apresentou o maior teor total de $\mathrm{Zn}$, diferente do teor observado na parcela tratada com adubação mineral. Os valores altos para o coeficiente de variação dos resultados na determinação do teor total de $\mathrm{Zn}$, principalmente nas amostras mais superficiais, impedem que se façam maiores considerações sobre a presença do Zn em profundidade, entretanto é importante salientar a tendência de maiores teores de Zn total nos tratamentos com as maiores doses de biossólidos o que pode ser um indicativo da movimentação de Zn ao longo do perfil.

Tabela 17 Teor de Zn-extraível no solo. Resultados expressos como média dos quatro blocos avaliados

\begin{tabular}{crrrrrr}
\hline Tratamento & \multicolumn{7}{c}{ Profundidades (cm) } \\
& $0-10$ & $10-20$ & $20-30$ & $30-60$ & $60-90$ \\
\hline C & $0,63 \mathrm{~b}^{(1)}$ & $0,53 \mathrm{~b}$ & $0,53 \mathrm{~b}$ & $0,48 \mathrm{~b}$ & $0,48 \mathrm{a}$ \\
AM & $0,63 \mathrm{~b}$ & $0,55 \mathrm{~b}$ & $0,55 \mathrm{~b}$ & $0,58 \mathrm{ab}$ & $0,43 \mathrm{a}$ \\
$10+\mathrm{K}$ & $3,00 \mathrm{~b}$ & $2,20 \mathrm{ab}$ & $1,85 \mathrm{ab}$ & $1,23 \mathrm{ab}$ & $0,78 \mathrm{a}$ \\
$10+\mathrm{KP}$ & $2,23 \mathrm{~b}$ & $2,25 \mathrm{ab}$ & $1,15 \mathrm{ab}$ & $0,85 \mathrm{ab}$ & $0,53 \mathrm{a}$ \\
$20+\mathrm{K}$ & $4,20 \mathrm{~b}$ & $2,18 \mathrm{ab}$ & $1,33 \mathrm{ab}$ & $0,73 \mathrm{ab}$ & $0,48 \mathrm{a}$ \\
$40+\mathrm{K}$ & $10,25 \mathrm{a}$ & $5,40 \mathrm{a}$ & $3,15 \mathrm{a}$ & $1,95 \mathrm{a}$ & $1,25 \mathrm{a}$ \\
Media & 3,49 & 2,18 & 1,43 & 0,97 & 0,65 \\
C.V. \% & 48,00 & 66,79 & 61,07 & 62,76 & 66,67 \\
\hline
\end{tabular}

(1) médias seguidas da mesma letra, na coluna, não diferem entre si pelo teste de Tukey (nível 5\% de significância)

A aplicação de $40 \mathrm{t} \mathrm{ha}^{-1}$ de biossólido complementado com $\mathrm{K}$ proporcionou teor de Zn-extraível no solo diferente do tratamento C (até $60 \mathrm{~cm}$ de profundidade), e do tratamento AM (até $30 \mathrm{~cm}$ de profundidade), 55 meses após aplicação do biossólido (Tabela 17). Pode-se, desse modo, afirmar que houve lixiviação de Zn no perfil do solo tratado com a maior dose de biossólido. Cabe ressaltar, que a ausência de diferenças 
significativas nos demais tratamentos com biossólido pode ser atribuída aos elevados valores de coeficiente de variação do Zn-extraível.

A porcentagem de Zn-extraível em relação ao teor total do metal foi maior no tratamento $40+\mathrm{K}$, independente da profundidade. Em geral, as porcentagens de $\mathrm{Zn}$ extraível em relação ao total decresceram com a profundidade.

Aumentos dos teores trocáveis de $\mathrm{Zn}$ em solos tratados com biossólidos têm sido observados em outros trabalhos (Camargo et al., 2003; Galdos et al., 2003). Melo et al. (2003) indicaram uma maior concentração de Zn-extraível (Mehlich 1, Mehlich 3 e DTPA) nos horizontes superficiais dos solos.

Em função do trabalho de Bertoncini (2002), pode-se sugerir que a mineralização das formas orgânicas, às quais o Zn estava associado no biossólido, contribuíram para o fornecimento do elemento ao solo. Entretanto, a mineralização dessa fração orgânica não é suficiente para explicar o acréscimo encontrado teor extraível de Zn no solo nos vários tratamentos, podendo ser indicativo de que outras frações às quais o Zn se encontrava associado sofreram solubilização no solo e que essas reações de solubilização não foram impedidas nem pelo maior $\mathrm{pH}$ do meio nem pela presença de fosfatos (com quem o $\mathrm{Zn}$ pode formar compostos de baixa solubilidade).

$\mathrm{Na}$ literatura existem diversos trabalhos com resultados que corroboram os aqui apresentados. Andreoli et al. (2003), não observaram acúmulo de Cd, Cr e Ni com a aplicação de doses crescentes de lodo de esgoto alcalino em Latossolo Vermelho Eutrófico. Estes autores obtiveram incrementos nos teores de $\mathrm{Cu}$ e $\mathrm{Zn}$ no solo proporcionais às doses aplicadas, sem, no entanto, aumentar a absorção e/ou acúmulo desses metais no tecido vegetal das plantas. Simonete \& Kiehl (2002) e Monterroso et al. (2003), também observaram incrementos significativos nos teores totais de Cu e Zn no solo, em função da adição de lodo de esgoto. Monterroso et al. (2003), ressaltam que embora não tenha sido detectado efeito fitotóxico isso não é sinônimo de ausência de transferência de Cu e Zn do solo para as plantas. Grassi-Filho et al. (2003), explicam a acumulação de $Z n$ na superfície do solo em função do incremento nos valores de matéria orgânica causado pela adição de biossólido. Por outro lado, Afyun et al. (2003) observaram níveis elevados de Ni e Cd no solo após aplicar lodo de esgoto em diferentes doses até $100 \mathrm{t} \mathrm{ha}^{-1}$. 


\subsection{Metais pesados nas folhas}

As concentrações de Cd e Cr nas folhas do eucalipto, 55 meses após a aplicação do biossólido, estiveram abaixo do limite de detecção do espectrofotômetro de absorção atômica utilizado na quantificação dos metais nos extratos. Isso indica concentrações de Cd inferiores a $0,006 \mu \mathrm{gL}^{-1}$ no extrato ou $0,06 \mathrm{~g} \mathrm{~kg}^{-1}$ na folha e, para o $\mathrm{Cr}$, concentrações inferiores a $0,05 \mu \mathrm{g} \mathrm{mL}^{-1}$ no extrato ou $0,5 \mathrm{~g} \mathrm{~kg}^{-1}$ na folha. Resultado semelhante foi encontrado por Andrade \& Mattiazzo (2000).

Tabela 18 Concentração de metais nas folhas. Resultados expressos como média dos quatro blocos avaliados

\begin{tabular}{|c|c|c|c|}
\hline Tratamento & $\mathrm{Cu}$ & $\mathrm{Ni}$ & $\mathrm{Zn}$ \\
\hline & \multicolumn{3}{|c|}{ 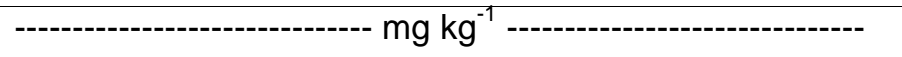 } \\
\hline C & $6,22 \mathrm{a}^{(1)}$ & $3,24 \mathrm{~b}$ & $17,68 \mathrm{ab}$ \\
\hline AM & 7,49 a & $3,49 \mathrm{~b}$ & $15,20 \mathrm{~b}$ \\
\hline $10+K$ & 12,44 a & $6,23 a b$ & $27,37 \mathrm{ab}$ \\
\hline $10+K P$ & 9,47 a & $4,99 \mathrm{ab}$ & $21,18 a b$ \\
\hline $20+K$ & 10,95 a & $4,23 a b$ & 30,40 a \\
\hline $40+K$ & 7,66 a & 7,83 a & 28,47 a \\
\hline Media & 9,54 & 5,00 & 23,38 \\
\hline C.V. \% & 27,64 & 34,27 & 23,89 \\
\hline
\end{tabular}

A concentração foliar de Cu não apresentou diferença significativa em função dos tratamentos avaliados, enquanto que para $\mathrm{Ni}$ e $\mathrm{Zn}$ foram diferentes (Tabela 18). No tratamento $40+\mathrm{K}$, a concentração média de Ni nas folhas do eucalipto foi superior às determinadas nas árvores dos tratamentos C e AM, evidenciando o aumento da fitodisponibilidade do metal em função da aplicação da maior dose de biossólido. Também foi observado aumento da fitodisponibilidade do Zn em função da aplicação do biossólido, porém, nesse caso, para as duas maiores doses do biossólido, 20 e $40 \mathrm{t} \mathrm{ha}^{-1}$, apenas quando comparados com o tratamento AM.

É importante ressaltar que os tratamentos que receberam $10 \mathrm{t} \mathrm{ha}^{-1}$ de biossólido não evidenciaram qualquer aumento da fitodisponibilidade dos metais $\mathrm{Cu}$, Ni e $\mathrm{Zn}$. Tal 
observação tem especial importância ao se considerar que o tratamento $10+K P$ tem mostrado as melhores respostas em termos de produção das árvores (Vaz, 2000; Rocha, 2002).

As concentrações médias obtidas para os micronutrientes $\mathrm{Cu}\left(9,5 \mathrm{mg} \mathrm{kg}^{-1}\right)$ e $\mathrm{Zn}$ $\left(23,4 \mathrm{mg} \mathrm{kg}^{-1}\right)$ não ultrapassaram o limite de concentração foliar considerada adequada para eucalipto (Gonçalves et al., 1997). Cabe salientar que, embora não tinham sido evidenciadas diferenças significativas entre os tratamentos, as concentrações foliares de $\mathrm{Cu}$, nos tratamentos $10+\mathrm{K}$ e $20+\mathrm{K}$, estiveram acima da faixa recomendada (7-10 $\mathrm{mg} \mathrm{kg}^{-1}$ ) e a do tratamento controle ficou abaixo dela.

Guedes \& Poggiani (2003), avaliando as concentrações foliares de Cu, aos dois, quatro, seis, oito, doze e dezesseis meses após aplicação de biossólido, na mesma área experimental, observaram diferenças significativas apenas entre o tratamento 10+K (29 mg kg-1) e o AM (15 mg kg $\left.{ }^{-1}\right)$, independente da época de coleta. Com relação ao Zn, os autores obtiveram uma concentração significativamente menor no tratamento AM (considerando as seis épocas de coleta) do que nas árvores dos outros tratamentos. Este resultado foi atribuído ao fato das árvores do tratamento AM terem recebido fósforo mineral no plantio, que exerceu interação negativa com o Zn devido à inibição não competitiva. $O$ tratamento "10+KP", que também recebeu $P$ mineral na base, não diferiu dos que receberam as maiores doses de biossólido, devido à liberação de Zn contido no biossólido. Andrade \& Mattiazzo (2000), doze meses após aplicação do biossólido, na mesma área experimental, não observaram efeito significativo do material aplicado nas diferentes doses sobre a concentração de $\mathrm{Cu}, \mathrm{Ni}$ e Zn nas folhas do eucalipto. Os trabalhos de Guedes \& Poggiani (2003) e de Andrade \& Mattiazzo (2000) basearam-se em amostras de folhas coletadas no terço superior das copas das árvores.

\subsection{Correlação solo-folha dos teores de $\mathrm{Cu}$, Ni e Zn}

As correlações entre os teores totais e extraíveis de Cu no solo, 0-10, 10-20, 20-30, 30-60 e 60-90 cm de profundidade, e as concentrações foliares de Cu não foram significativas (Tabela 19 e 20). Indicando assim que, no presente trabalho, o extrator Mehlich 3 não foi eficiente na previsão da disponibilidade do Cu para o eucalipto. 
Para o Ni e o Zn houve correlação significativa dos teores totais e extraíveis desses metais no solo e nas folhas do eucalipto, apenas quando considerada a camada 0-10 $\mathrm{cm}$ de profundidade (Tabela 19 e 20). O fato de a correlação ter sido significativa tanto com os teores de $\mathrm{Ni}$ e $\mathrm{Zn}$ totais no solo, quanto com os teores extraíveis, é indicativo que as quantidades fitodisponíveis são proporcionais ao teor total do elemento e que o extrator Mehlich 3 foi eficiente na previsão da disponibilidade desses metais para o eucalipto. Diversos trabalhos têm evidenciado boa eficiência do extrator Mehlich 3 na previsão da fitodisponibilidade de $\mathrm{Cu}$, Ni e Zn para algumas culturas como milho (Anjos \& Mattiazzo, 2001; Martins et al., 2003) e arroz (Pires \& Mattiazzo, 2003). Já, Andrade \& Mattiazzo (2000) não observaram boa eficiência do Mehlich 3 na previsão da fitodisponibilidade de Cu e Zn para plantas de eucalipto.

Tabela 19 Coeficiente de correlação entre concentração foliar e teor total de $\mathrm{Cu}, \mathrm{Ni}$ e Zn no solo

\begin{tabular}{cccc}
\hline Profundidade $(\mathrm{cm})$ & $r^{2}$ (Cu-total/Cu-folha) & $r^{2}$ (Ni-total/Ni-folha) & $r^{2}$ (Zn-total/Zn-folha) \\
\hline $0-10$ & $-0,14$ & $0,58^{*}$ & $0,50^{\star}$ \\
$10-20$ & $-0,16$ & 0,37 & 0,30 \\
$20-30$ & 0,05 & $-0,07$ & 0,35 \\
$30-60$ & $-0,01$ & 0,14 & $0,57^{\star}$ \\
$60-90$ & $-0,11$ & 0,27 & 0,31
\end{tabular}

(*) significativo ao nível de $\mathrm{p}>\mathrm{t}=0,05$

Tabela 20 Coeficiente de correlação entre concentração foliar e teor extraível (Mehlich 3) de $\mathrm{Cu}$, Ni e Zn no solo

\begin{tabular}{cccc}
\hline Profundidade $(\mathrm{cm})$ & $r^{2}$ (Cu-extr./Cu-folha) & $r^{2}$ (Ni-extr./Ni-folha) & $r^{2}$ (Zn-extr./Zn-folha) \\
\hline $0-10$ & $-0,06$ & $0,60^{*}$ & $0,45^{*}$ \\
$10-20$ & $-0,03$ & 0,21 & 0,37 \\
$20-30$ & $-0,12$ & 0,26 & 0,39 \\
$30-60$ & 0,23 & 0,08 & 0,36 \\
$60-90$ & 0,22 & 0,04 & 0,37 \\
\hline
\end{tabular}

$\left(^{*}\right)$ significativo ao nível de $\mathrm{p}>\mathrm{t}=0,05$ 


\section{CONCLUSÕES}

Como resultado deste trabalho, referente à utilização de biossólido, 55 meses anos após sua aplicação em superfície, podê-se concluir que:

1. embora a aplicação de biossólido em quantidades superiores a $20 \mathrm{t} \mathrm{ha}^{-1}$ tenha resultado em aumento dos teores de $\mathrm{N}$-total em profundidade no solo, este incremento não supõe riscos ambientais diferentes dos decorrentes da fertilização mineral;

2. a concentração foliar de nitrogênio não foi influenciada pelo aporte de nitrogênio do biossólido;

3. as doses utilizadas de biossólido não proporcionaram aumentos nos teores dos metais $\mathrm{Cd}$ e $\mathrm{Cr}$ no solo e não foram verificadas evidências de fitodisponibilidade desses metais;

4. os teores de $\mathrm{Cu}$, Ni e Zn extraíveis aumentaram com o tempo decorrido desde a aplicação do biossólido, indicando a possibilidade de mobilidade e fitodisponibilidade desses metais no solo quando da aplicação do biossólido na dose de $40 \mathrm{t} \mathrm{ha}^{-1}$ (base seca). Não obstante, estes aumentos não representaram risco para a cultura do eucalipto. 


\section{REFERÊNCIAS BIBLIOGRÁFICAS}

ABREU, M.F.; ABREU, C.A.; ANDRADE, J.C. Determinação de fósforo, potássio, cálcio, magnésio, enxofre, cobre, ferro, manganês, zinco, níquel, cádmio, cromo e chumbo em ácido nítrico usando métodos da US-EPA. In: RAIJ, B. van; ANDRADE, J.C.; CANTARELLA, H.; QUAGGIO, J.A. (Ed.). Análise química para avaliação da fertilidade de solos tropicais. Campinas: Instituto Agronômico, 2001. p.251261.

ACCIOLY, A.M.A.; SIQUEIRA, J.O. Contaminação química e biorremediação do solo. In: NOVAIS, R.F.; ALVAREZ, V.H.; SCHAEFER, C.E.G.R. Tópicos em ciência do solo. Viçosa: Sociedade Brasileira de Ciências do Solo, 2000. 352p.

ADRIANO, D. C. Trace elements in terrestrial environment. New York: Spingler Verlag, 1986. $533 \mathrm{p}$.

AFYUN, M.; KHADIVI, I.; SHARIATMADARI, H.; SCHULIN, R. Fractionation of Cd, Pb and $\mathrm{Ni}$ in a haplargid soil amended with sewage sludge (compact disc). In: INTERNATIONAL CONFERENCE ON THE BIOGEOCHEMISTRY OF TRACE ELEMENTS, 7., Uppsala, 2003.

ALLOWAY, B.J. Heavy metals in soils. London: Blackie Academic and Profeesional Publishers, 1995.

ALLOWAY, B.J.; AYRES, D.C. Chemical principles of environmental pollution. 2.ed. London: Chapman \& Hall, 1997. 395p.

ANDRADE, C.A. Nitratos e metais pesados no solo e em plantas de Eucaliyptus grandis após aplicação de biossólido da ETE de Barueri. Piracicaba, 1999. 65p. Disertação (Mestrado) - Escola Superior de Agricultura "Luiz de Queiroz", Universidade de São Paulo. 
ANDRADE, C.A.; MATTIAZZO, M.E. Volatilização de amônia após adição de lodo de esgoto a um Latossolo Vermelho-Amarelo (compact disc). In: CONGRESSO BRASILEIRO DE CIÊNCIA DO SOLO, 27., Brasília, 1999.

ANDRADE, C.A.; MATTIAZZO, M.E. Nitratos e metais pesados no solo e nas árvores após aplicação de biossólido (lodo de esgoto) em plantações florestais de Eucalyptus grandis. Scientia Forestalis, v.58, p.59-72, 2000.

ANDREOLI, C.V.; LARA, A.L.; FERNANDES, F. Reciclagem de biossólido: transformando problemas em soluções. Curitiba: SANEPAR; FINEP, 1999. 288p.

ANDREOLI, C.V.; FERREIRA, A.C.; PEGORINI, E.S.; SOUZA, M.L.P. Efeito da aplicação de lodo de esgoto nos teores de metais pesados de solos, folhas e grão de milho (compact disc). In: CONGRESSO BRASILEIRO DE CIÊNCIA DO SOLO, 29., Ribeirão Preto, 2003.

ANJOS, A.R.M.; MATTIAZZO, M.E. Extratores para $\mathrm{Cd}, \mathrm{Cu}, \mathrm{Cr}, \mathrm{Mn}, \mathrm{Pb}$ e $\mathrm{Zn}$ em latossolos tratados com biossólido e cultivados com milho. Scientia Agrícola, v.58, n.2, p.337-344, 2001.

ANJOS, A.R.M.; MATTIAZZO, M.E. Metais pesados em plantas de milho cultivadas em latossolos repetidamente tratados com biossólido. Scientia Agricola, v.57, n.4, p.769-776, 2000.

AYUSO, M.; PASCUAL, J.A; GARCÍA, C.; HERNÁNDEZ, T. Evaluation of urban wastes for agriculture use. Soil Science and Plant Nutrition, v.42, n.1, p.105-111, 1996.

BARBOSA, G. M. C.; FILHO, J.T.; FONSECA, I.C. B. Avaliações de propriedades físicas de um Latossolo Vermelho eutroférrico tratado com lodo de esgoto por dois anos consecutivos, 2002. www.sanepar.com.br (17/02/2004).

BEAUCHAMP, E.G.; REYNOLDS, W.D.; BRASCHE-VILLENEUVE, D.; KIRBY, K. Nitrogen mineralization kinetics with different soil pretreatments and cropping histories. Soil Science Society American Journal, v.50, p.1478-1483, 1996.

BERTON, R.S. Fertilizantes e poluição. In: REUNIÃO BRASILEIRA DE FERTILIDADE DO SOLO E NUTRIÇÃO DE PLANTAS, 20., Piracicaba, 1992. Anais. Campinas: Fundação Cargill, 1992. p.299-313. 
BERTON, R.S.; CAMARGO, A.O.; VALADARES, J.M.A.S. Absorção de nutrientes pelo milho em resposta à adição de lodo de esgoto a cinco solos paulistas. Revista Brasileira de Ciência do Solo, v.13, p.187-192, 1989.

BERTON, R.S.; VALADARES, J.M.A.S.; CAMARGO, O.A.; BATAGLIA, O.C. Peletização de biossólido e adição de $\mathrm{CaCO}_{3}$ na produção de matéria seca e absorção de Zn, Cu e Ni pelo milho em três latossolos. Revista Brasileira de Ciência do Solo, v.21, p.685-691, 1997.

BERTONCINI, E.I. Comportamento de $\mathrm{Cd}, \mathrm{Cr}, \mathrm{Cu}, \mathrm{Ni}$ e $\mathrm{Zn}$ em Latossolos sucessivamente tratados com biossólido: extração seqüencial, fitodisponibilidade e caracterização de substâncias húmicas. Piracicaba, 2002. 195p. Tese (Doutorado) Escola Superior de Agricultura "Luiz de Queiroz", Universidade de São Paulo.

BERTONCINI, E.I.; MATTIAZZO, M.E. Lixiviação de metais pesados em solos tratados com lodo de esgoto. Revista Brasileira de Ciência do Solo, v.23, n.3, p.737-744, 1999.

BOARETTO, A.E. Uso de lodo de esgoto como fertilizante. Botucatu: UNESP, FINEP, 1986. 185 p.

BOEIRA, R.C. (s.d.) Reutilização de lodo de esgoto como adubo nitrogenado: risco ou benefício ao meio ambiente?, 2000. www.boletimpecuario.com.br (17/02/2004).

BOEIRA, R.C.; MAXIMILIANO, V.C.B.; MADARI, B. Efeito residual de quatro aplicações de lodos de esgoto sobre a disponibilidade de nitrogênio (compact disc). In:CONCRESSO BRASILEIRO DE CIÊNCIA DO SOLO, 29., Riberão Preto, 2003. BRASIL. Ministério da Saúde. Portaria n.1469/2000: Normas de qualidade da água para consumo humano. Brasília, 2000.

BUTING, A.H. Experiments on organic manures. Journal of Agricultural Science, v.60, p.121-140, 1963.

CAMARGO, O.A.; MARTINS, A.L.C.; BATAGLIA, O.C. Heavy metals accumulation in a orthox soil amended with sewage sludge and limestone (compact disc). In: INTERNATIONAL CONFERENCE ON THE BIOGEOCHEMISTRY OF TRACE ELEMENTS, 7., Uppsala, 2003. 
CAMARGO, O.A.; MONIZ, A.C.; JORGE, J.A.; VALADARES, J.M.A.S. Métodos de análise química, mineralógica e física de solos do Instituto Agronômico de Campinas. Campinas: IAC, 1986. 94p. (IAC. Boletim Técnico, 106).

CARDOSO VIGUEROS, L. Aplicación en un suelo agrícola de lodos residuales tratados. In: CONGRESO INTERAMERICANO DE INGENIERÍA SANITARIA Y AMBIENTAL, 28., Cancún, 2002.

CARNEIRO, C.; SOTTOMAIOR, A.P.; ANDREOLI, C.V. estudo da dinâmica de nitrogênio em perfil de lodo de esgoto (compact disc). In: CONGRESSO BRASILEIRO DE CIÊNCIA DO SOLO, 29., Ribeirão Preto, 2003.

CARVALHO, P.C.T.; BARRAL, M.F. Aplicação de lodo de esgoto como fertilizante. Fertilizantes, v.63, n.2, p.1-4, 1981.

CASTRO, L.A.R.; ANDREOLI, C.V.; PEGORINI, E.S.; TAMANINI, C.R.; FERREIRA, A.C. Efeitos do lodo de esgoto como recuperador de áreas degradadas com finalidade agrícola. In: SIMPOSIO NACIONAL SOBRE RECUPERAÇÃO DE ÁREAS DEGRADADAS, 5., Belo Horizonte, 2002. www.sanepar.com.br (17/02/2004).

CENTRO NACIONAL DE REFERENCIA E GESTÃO AMBIENTAL E URBANA. Utilização agrícola do lodo de esgoto como fertilizante. 2001. www.bis.com.br/unilivre/centro/experiência/015.html (17/02/2004).

CENTURION, C. A; CAMARGO, O. A. Biodisponibilidade do zinco, cobre e níquel após quinze anos de aplicação de biossólido (compact disc). In: CONGRESSO BRASILEIRO DE CIÊNCIA DO SOLO, 29., Ribeirão Preto, 2003. Resumos. Ilha Solteira: SBCS; UNESP/FCA.

COMPANHIA DE TECNOLOGIA DE SANEAMENTO AMBIENTAL. Aplicação de biossólidos de sistemas de tratamento biológico em áreas agrícolas: critérios para projeto e operação; manual técnico, norma P4.230. São Paulo, 1999. 35p.

COX, D.A. Pelletized sewage sludge as fertilizer for containerizer plants: plant growth and nitrogen leaching losses. Journal of Plant Nutrition, v.18, n.12, p.2783-2795, 1995 
DANCER, W.S.; PETERSON, L.A.; CHESTERS, G. Ammonification and nitrification of $\mathrm{N}$ as influenced by soil $\mathrm{pH}$ and previous $\mathrm{N}$ treatments. Soil Science Society of America Proceedings, v.37, n.1, p.67-69, 1973.

EATON A.D.; CLESCERI, L.S.; GREENBERG, A.E. Standard methods for the examination of water and waster. 19.ed. Washington: American Public Health Association; American Water Works Association; Water Environment Federation, 1995. 533p.

ESTADOS UNIDOS. Environmental Protection Agency. Standards for use or disposal of sewage sludge. Washington, 1997. 25p. (Code of Federal Regulations 40 CFR Part 403 and 503).

FARIA, L.C. Fertilização de povoamento de eucalipto com biossólido da ETE de Barueri, SP: demanda potencial e nível mínimo e resposta. Piracicaba, 2000. 85p. Dissertação (Mestrado) - Escola Superior de Agricultura "Luiz de Queiroz" Universidade de São Paulo.

FLETCHER, P.; BECKETT, P.H.T. The chemistry of heavy metals in digested sewage sludge - II - Heavy metal complexation with soluble organic matter. Water Resource, v.21, p.1163-1172, 1987.

FRANCO, A.; MARQUES, M.O.; GATTO, R.H.; NOGUEIRA, A.E.; F. CAMILOTTI, F.; NÓBILE, F.O.; TASSO JÚNIOR, L.C. Cana-de-açúcar cultiva com lodo de esgoto e vinhaça: nitrogênio no solo e plantas (compact disc). In: CONGRESSO BRASILEIRO DE CIÊNCIA DO SOLO, 29., Ribeirão Preto, 2003.

GALDOS, M.V.; MARIA, I.C.; CAMARGO, O.A. Alterações em propriedades químicas de um Latossolo Vermelho Eutrófico tratado com lodo de esgoto (compact disc). In: CONGRESSO BRASILEIRO DE CIÊNCIA DO SOLO, 29., Ribeirão Preto, 2003.

GONÇALVES, J.L.M.; RAIJ, B. van; GONÇALVES, J.C. Florestais. In: RAIJ, B. van; CANTARELLA, H.; QUAGGIO, J.A.; FURLANI, A.M.C. (Ed.). Recomendações de adubação e calagem para o Estado de São Paulo. 2.Ed. Campinas: Instituto Agronômico de Campinas \& Fundação IAC, 1997. p.245-260. (Boletim Técnico 100) 
GONÇALVES, J.L.M.; STAPE, J.L.; BENEDETTI, V.; FESSEL, V.A.G.; GAVA, J.L. Reflexos do cultivo mínimo e intensidade do solo em sua fertilidade e na nutrição das árvores. In: GONÇALVES, J.L.M.; BENEDETTI, V. (Ed.). Nutrição e fertilização florestal. Piracicaba: IPEF, 2000. p.3-57.

GONÇALVES, T.D. Mapeamento de solos e de produtividade em plantações de Eucalyptus grandis na Estação Experimental de Itatinga, ESALQ, com uso de geoprocessamento. Piracicaba, 2003. 47p. Dissertação (Mestrado) - Escola Superior de Agricultura "Luiz de Queiroz", Universidade de São Paulo.

GRASSI FILHO, H.; SANTOS, C.H.; TORQUATO, E. M.; PENTEADO, B.B; SANTOS, J.C. Acúmulo de micronutrientes no solo manejado com biossólido e cultivado com tangerineira "poncã" (compact disc). In: CONGRESSO BRASILEIRO DE CIÊNCIA DO SOLO, 29., Ribeirão Preto, 2003.

GUEDES, M.C. Efeito do lodo de esgoto (biossólido) sobre a nutrição, ciclagem de nutrientes e crescimento de sub-bosque, em plantação de eucalipto. Piracicaba, 2000. 74p. Dissertação (Mestrado) - Escola Superior de Agricultura "Luiz de Queiroz", Universidade de São Paulo.

HARRISON, R.B.; REIS, M.G.F.; REIS G.F.; GONÇÃLVES, J.L.M.; HENRY, C.L.; COLE, D.W.; KING, R.; LEONARD, P.; COMPTON, J.; XUEL, D. Closing the loop: the rule of harvesting and transportation in maintaining productivity and returning organic waste to the forest. In: SEMINÁRIO DE ATUALIZAÇÃO SOBRE SISTEMAS DE COLHEITA DE MADEIRA E TRANSPORTE FLORESTAL, 9., Curitiba, 1996. Anais. Curitiba: UFPR, 1996. p.101-118.

HENRY, C.L.; COLE, D.W.; HARRISON, R.B.; BENGTSSON, J.; LUNDKVIST, H. Use of municipal sludge to restore an improve site productivity in forestry: the Pack Forest Sludge Research Program. Forest Ecology Management, v.66, n.1/3, p.137-149, 1994.

HUGHES, M.K. Cycling of trace metal in ecosystems. In: LEPP, N.M. (Ed.). Effects of heavy metal pollution on plants. London: Applied Science, 1981. p.95-118. 
ISEA, D.; VARGAS, L.; BELLO, N.; DELGADO, J.G. Lixiviación de metales no nutrientes en suelos sometidos a riego con aguas residuales tratadas. In: CONGRESSO INTERAMERICANO DE ENGENHARIA SANITÁRIA E AMBIENTAL, 27., Porto Alegre, 2000. Anais: ABES, 2000.

KABATA-PENDIAS, A. Agricultural problems related to excessive trace metal contents of soils. In: SALOMONS, W.; FORSTNER, U.; MADER, P. Heavy metals: problems and solutions. Berlin: Springer-Verlag, 1995.

KABATA-PENDIAS, A.; PENDIAS, $H$. Trace elements in soils and plants. 2.ed. Boca Raton: CRC Press. 1992. 365p.

KIEHL, E.J. Fertilizantes orgânicos. Piracicaba: Agronômica Ceres, 1985. 492p.

LANDONIN, D.V.; MARGOLINA, S.E. Interactions between humic acids and heavy metals. Eurasian Soil Science, v.30, n.7, p.710-715, 1997.

LASAT, M.M. Phytoextration of metals from contaminated soil: a review of plant/soil/metal interaction and assessment of pertinent agronomic issues. Journal of Hazardous Substance Reserch, v.2, 25p., 2000.

LUO, Y.M.; QIAO, X.L.; WU, L.H.; SONG, J. Leachability of nitrate and Zn in biosolidamended soils (compact disc). In: INTERNATIONAL CONFERENCE ON THE BIOGEOCHEMISTRY OF TRACE ELEMENTS, 7., Uppsala, 2003.

MARQUES, M.O. Incorporação de lodo de esgoto em solo cultivado com cana-deaçúcar. Jaboticabal, 1997. 111p. Tese (Livre Docência) - Faculdade de Ciências Agrárias e Veterinárias, Universidade Estadual Paulista.

MARTINS, A.L.C.; BATAGLIA, O.C.; CAMARGO, O.A. Fitodisponibilidade de cobre, níquel e zinco em um Latossolo Vermelho tratado com lodo de esgoto e calagem, Scientia Agricola, v.60, n.4, p.747-754, 2003.

MATTIGOD, S.V.; SPOSITO, G.; PAGE, A.L. Factors affecting the solubility of trace metals in soils. In: DOWDY, R.H.; RYAN, J.A.; VOLT, V.V.; BAKER, D.E. Chemistry in the soil environment. Madison: ASA, 1981. p.203-221. (ASA, Special Publication, 40).

MATTIAZZO-PREZOTTO, M.E. Química ambiental e agronomia In: REUNIÃO BRASILEIRA DE FERTILIDADE DO SOLO E NUTRIÇÃO DE PLANTAS, 22., Piracicaba, 1992. Anais. Campinas: Fundação Cargill, 1992. p.157-178. 
MATTIAZZO-PREZOTTO, M.E. Comportamento de cobre, cádmio, crômio, níquel e zinco adicionados a solos de clima tropical em diferentes valores de pH. Piracicaba, 1994. 197p. Tese (Livre Docência) - Escola Superior de Agricultura "Luiz de Queiroz", Universidade de São Paulo.

MEDALIE, L.; BOWDEN, W.B.; SMITH, C.T. Nutrient leaching following land application of aerobically digested municipal sewage sludge in Northern Hardwood Forest. Journal of Environmental Quality, v.23, n.1, p.130-138. 1994.

MEHLICH, A. Mehlich 3 soil test extractant: a modification of Mehlich 2 extractan. Communications in Soil Science and Plant Analysis, v.15, n.12, p.1409-1416, 1984.

MELO, W.J.; MARQUES, M.O.; SILVA, F.C.; BOARETTO, A.E. Uso de resíduos sólidos urbanos na agricultura e impactos ambientais (compact disc). In: CONGRESSO BRASILEIRO DE CIÊNCIA DO SOLO, 26., Rio de Janeiro, 1997.

MELO, W.J.; TSUTIYA, M.T.; MARQUES, M.O.; BOTTO E SOUZA, A.H.C.; Nível de fertilidade em solos tratados com biossólido oriundo da ETE de Barueri, localizada na região metropolitana de São Paulo, e cultivado com milho. In: CONGRESSO INTERAMERICANO DE ENGENHARIA SANITÁRIA E AMBIENTAL, 27., Porto Alegre. Anais: ABES. 2000.

MELO, E.E.C.; NASCIMENTO, C.W.A.; OLIVEIRA, A.B.; NASCIMENTO, R.S.M.P. Avaliação de diferentes métodos para determinação dos teores totais e disponíveis de zinco em solos de Pernambuco (compact disc). In: CONGRESSO BRASILEIRO DE CIÊNCIA DO SOLO, 29., Ribeirão Preto, 2003.

MELO, W.J.; MARQUES, M.O.; SANTIAGO, G.; CHELLI, R.A.; LEITE, S.A.A. Efeito de doses crescentes de lodo de esgoto sobre frações de matéria orgânica e CTC de um Latossolo cultivado com cana-de-açúcar. Revista Brasileira de Ciência do Solo, v.18, p.449-455, 1994.

MIKI, M.K.; ANDRIGUETI, E.J.; SOBRINHO, P.A. Tratamento de fase sólida em estação de tratamento de esgotos. In: TSUTIYA, M.T.; COMPARINI, J.B., SOBRINHO, P.A.; HESPANHOL, I.; CARVALHO, P.C.T.; MELFI, A.J.; MELO, W.J.; MARQUES, M.O. (Ed.). Biossólidos na agricultura. 1.ed. São Paulo: SABESP, 2001. p.41-88. 
MISSELBROOK, T.H.; SHEPHERD, M.A.; PAIN, B.F. Sewage sludge applications to grassland: influence of sludge type, time and method of application on nitrate leaching and herbage yield. Journal of Agricultural Science, v.126, n.3, p.343352. 1996.

MONTERROSO, C.; KIDD, P.; MACÍAS, F. Bioavailability of heavy metals in sewage sludge-amended soils as affected by soil parent material (compact disc). In: INTERNATIONAL CONFERENCE ON THE BIOGEOCHEMISTRY OF TRACE ELEMENTS, 7., Uppsala, 2003.

MORO, M. Caracterização, distribuição e análise econômica dos resíduos industriais da Champion Papel e Celulose Ldta. In: SEMINÁRIO SOBRE O USO DE RESÍDUOS INDUSTRIAIS E URBANOS EM FLORESTAS, Botucatu, 1994. Anais. Botucatu: UNESP, FCA, 1994. p.155-166.

MULVANEY, R.L. Methods for determination of inorganic nitrogen en soil. In: SPARKS, D.L. (Ed.). Methods of soils analysis: chemical methods. Madison: SSSA; ASA, 1996. p.1125-1139.

NOVAIS, R.F.; BARROS, N.F.; NEVES, J.C.L. Nutrição mineral do eucalipto. In: BARROS, N.F.; NOVAIS, R.F. (Ed.). Relação solo-eucalipto. Viçosa. Editora Folha de Viçosa, 1990. p.25-98.

NYBORG, M.; HOYT, P.B. Effects of soil acidity and liming on mineralization of soil nitrogen. Canadian Journal of Soil Science, v.58, p.331-338, 1978.

OLIVEIRA, F.C. Comportamento de metais pesados e formas nitrogenadas em solos tratados com lodos de esgoto. Piracicaba. 1995. 91p. Dissertação (Mestrado) Escola Superior de Agricultura "Luiz de Queiroz", Universidade de São Paulo.

OLIVEIRA, F.C.; MATTIAZZO, M.E. Mobilidade de metais pesados em um Latossolo Amarelo distrófico tratado com lodo de esgoto e cultivado com cana-de-açúcar, Scientia Agricola, v.58, n.4, p.807-812, 2001.

OLIVEIRA, F.C.; MATTIAZZO, M.E.; MARCIANO, C.R.; MORAES, S.O. Lixiviação de nitrato em um Latossolo Amarelo Distrófico tratado com lodo de esgoto e cultivado com cana-de-açúcar. Scientia Agricola, v.58, n.1, p.171-180, 2001. 
OLIVEIRA, F.C.; MATTIAZZO, M.E.; MARCIANO, C.R.; ROSSETTO, R. Efeitos de aplicações sucessivas de lodo de esgoto em um Latossolo Amarelo Distrófico cultivado com cana-de-açúcar: carbono orgânico, condutividade elétrica, pH e CTC. Revista Brasileira de Ciências do Solo, v.26, n.2, p.505-519, 2002.

ORGANIZAÇÃO MUNDIAL DA SAÚDE. Guidelines for the safe use of waster and excreta in agriculture and aquaculture: measures for public health protection; executive summary. http://www.who.org (s.d.).

PARKER, C.F.; SOMMERS, L.E. Mineralization of nitrogen in sewage sludges. Journal of Environmental Quality, v.12, p.150-156, 1983.

PIRES, A.M.M. Ácidos orgânicos da rizosfera: aspectos qualitativos e quantitativos e fitodisponibilidade de metais pesados originários de biossólido . Piracicaba. 2003. 94p. Tese (Doutorado) - Escola Superior de Agricultura "Luiz de Queiroz", Universidade de São Paulo.

PIRES, A.M.M.; MATTIAZZO, M.E. Condicionamento de biossólidos e a disponibilidade de Cu e Zn para arroz. Scientia Agricola, v.60, n.1, p.161-166, 2003.

POGGIANI, F.; BENEDETTI, V. Aplicabilidade do lodo filtrado de esgoto produzido na Região Metropolitana de São Paulo em plantações florestais de rápido crescimento. Piracicaba: ESALQ; IPEF; SABESP, 2000. 111p.

POGGIANI, F.; GUEDES, M.C.; BENEDTTI, V.. Aplicabilidade do biossólido em plantações florestais: 1-Reflexos no ciclo dos nutrientes. In: BETTIOL, W.; CAMARGO, O.A. (Ed.). Impacto ambiental do uso agrícola do lodo de esgoto. Jaguariúna: Embrapa, 2000. p.163-178.

RAIJ, B. van Uso agrícola de biossólido. In: SEMINÁRIO SOBRE GERENCIAMENTO DE BIOSSÓlIDO DO MERCOSUL, 1., Curitiba, 1998. Palestras. Curitiba: SANEPAR; ABES, 1998. p.147-151.

RAIJ, B. van; QUAGGIO, J.A. Métodos de análise de solo para fins de fertilidade. Campinas: IAC, 1983. 40p. (IAC. Boletim Técnico, 81).

Revista da Madeira, Pesquisas otimizam recursos e diversificam produção, n.75, ano 13, 2003. www.remade.com.br (17/02/2004). 
ROCHA, G.N. Monitoramento da fertilidade do solo, nutrição mineral e crescimento de um povoamento de Eucalyptus grandis fertilizado com biossólido. Piracicaba, 2002. 48p. Dissertação (Mestrado) - Escola Superior de Agricultura "Luiz de Queiroz", Universidade de São Paulo.

RODELLA, A.A. Determinação espectrofotométrica automatizada de cobre e zinco em amostras de interesse agroindustrial por métodos cinéticos. Campinas, 1993. 132p. Tese (Doutorado) - Instituto de Química, UNICAMP.

RYAN, J. A.; KEENEY, D.R.; WALSH, L. M. Nitrogen transformations and availability of anaerobically digested sewage sludge in soil. Journal of Environmental Quality, v.2, p.489-492, 1973.

SABEY, B.R. The use of sewage sludge as a fertilizer. Environmental Engineering Series, v.72, p.108-112, 1974.

SANTOS, H.F.; TSUTYA, M.T.; Aproveitamento e disposição final do lodo de esgoto de ETEs do Estado de São Paulo. Engenharia Sanitária e Ambiental, v.2, n.2, p.70-82, 1997.

SILVA, C.A.; VALE, F.R.; ANDERSON, S.J.; KOBAL, A.R. Mineralização de nitrogênio e enxofre em solos brasileiros sob influência da calagem e fósforo, Pesquisa Agropecuária Brasileira, v.34, n.9, p.1679-1689, 1999.

SILVA, F.C.; BOARETTO, A.E.; BERTON, R.S.; ZOTELLI, H.B.; PEIXE, C.A.; MENDOÇA, E. Cana-de-açúcar cultivada em solo adubado com lodo de esgoto: nutrientes, metais pesados e produtividade. Pesquisa Agropecuária Brasileira, v.13, p.1-8, 1998.

SILVA, F.C.; BOARETTO, A.E.; BERTON, R.S.; ZOTELLI, H.B.; PEIXE, C.A.; MENDOÇA, E. Efeito de lodo de esgoto na fertilidade de um Argissolo VermelhoAmarelo cultivado com cana-de-açúcar. Pesquisa Agropecuária Brasileira, Brasília, v. 36, n. 5, p. 831-840, 2001.

SIMÃO, J.B.P.; SIQUEIRA, J.O. Solos contaminados por metais pesados: características, implicações e remediação. Informe Agropecuário, v. 22, n.210, p.18-26, 2001. 
SIMONETE, M.A., KIEHL, J.C. Extração e fitodisponibilidade de metais pesados em resposta à adição de lodo de esgoto no solo. Scientia Agricola, v.59, n.3, p.55-63, 2002.

SOARES, M.T.S. Taxa de mineralização e de lixiviação do nitrogênio, e alterações da fertilidade de um latossolo vermelho-amarelo degradado e outro não-degradado fertilizados com biossólido e florestados com Eucalyptus grandis. Piracicaba, 2003. 142p. Tese (Doutorado) - Escola Superior de Agricultura "Luiz de Queiroz", Universidade de São Paulo.

SOUZA, S.B.S.; CORAUCCI FILHO, B.; STEFANUTTI, R.; SILVA, R.S.P.; FIGUEIREDO, R.P.; GUIMARÃES, J.R. Reuso de efluente doméstico em irrigação: avaliação da contaminação por nitrito e nitrato no perfil do solo (compact disc). In: CONGRESSO BRASILEIRO DE CIÊNCIA DO SOLO, 29., Ribeirão Preto, 2003.

SPARKS, D.L. Environmental soil chemistry. California: Academic Press, 1995. $267 p$.

SPOSITO, G. The chemistry of soils. New York: Oxford University Press, 1989. 277p.

STANFORD, G.; SMITH, S.J. Nitrogen mineralization potencials of soils. Soil Science Society American Proceeding, v.63, p.465-472, 1972.

STEVENSON, F.J. Cycles of Soil. Canada: John Wiley \& Sons, 1986. 380p.

TEDESCO, M. J.; GIANELLO, C.; BISSANI, C. A.; BOHEN, H.; VOLKWEISS, S. J. Análise de solo, plantas e outros materiais. Porto Alegre: UFRGS, 1995. 174 p.

TSUTIYA, M.T. Metais pesados: o principal fator limitante para o uso agrícola de biossólidos das estações de tratamento de esgotos. In: CONGRESSO BRASILEIRO DE ENGENHARIA SANITÁRIA E AMBIENTAL, 20., 1999.

TSUTYA, M.T. Alternativas de disposição final de biossólido gerados em estações de tratamento de esgoto. In: BETIOL, W.; CAMARGO, O.A. Impacto ambiental do uso agrícola do lodo de Esgoto. Jaguariúna: EMBRAPA Meio Ambiente, 2000. p.69-106.

TSUTYA, M.T. Características de biossólidos gerados em estações de tratamento de esgotos. In: TSUTIYA, M.T.; COMPARINI, J.B., SOBRINHO, P.A.; HESPANHOL, I.; CARVALHO, P.C.T.; MELFI, A.J.; MELO, W.J.; MARQUES, M.O. (Ed.). Biossólidos na agricultura. 1.ed. São Paulo: SABESP, 2001. p.41-88. 
VAZ, L.M.S. Crescimento inicial, fertilidade do solo e nutrição de um povoamento de Eucalyptus grandis fertilizado com biossólido. Piracicaba, 2000. 41p. Dissertação (Mestrado) - Escola Superior de Agricultura "Luiz de Queiroz", São Paulo.

VAZ, L.M.S.; GONÇALVES, J.L.M. Crescimento inicial e fertilidade do solo em um povoamento de Eucalyptus grandis fertilizado com biossólido. Sitientibus, v.26, p.151-174, 2002a.

VAZ, L.M.S.; GONÇALVES, J.L.M. Uso de biossólidos em povoamento de Eucalyptus grandis: efeito em atributos químicos do solo, no crescimento e na absorção de nutrientes. Revista Brasileira de Ciência do Solo, v.26, n.3, p.747-758, 2002b.

VEGA, F.V.A.; BOVI, M.L.A.; BERTON, R.S.; GODOY JÚNIO, G. Movimento vertical e horizontal de $\mathrm{NO}_{3}{ }^{-}$e $\mathrm{NH}_{4}{ }^{+}$, em solo tratado com lodo de esgoto, aplicado no plantio de pupunheira (compact disc). In: CONGRESSO BRASILEIRO DE CIÊNCIA DO SOLO, 29., Ribeirão Preto, 2003.

VIEIRA, R.F.; CARDOSO, A.A. Variações nos teores de nitrogênio mineral em solo suplementado com lodo de esgoto, Pesquisa Agropecuária Brasileira, v.38, n.7, p.867-874, 2003.

WANG, M. Land application of sewage in China. The Science of Total Environment, v.197, n.1/3, p.149-160, 1997.

ZEN, S.; BELLOTE, A.F.J.; SILVA, H.D. Resíduos urbanos como fonte de nutrientes em povoamentos de eucalipto. In: SEMINÁRIO SOBRE O USO DE RESÍDUOS INDUSTRIAIS E URBANOS EM FLORESTAS, Botucatu, 1994. Anais. Botucatu: UNESP, FCA, 1994. p.25-39. 
APÊNDICE 
APÊNDICE 1 - Valor pH dos tratamentos. Resultados expressos como média dos quatro blocos avaliados expresso como média dos quatro blocos avaliados

\begin{tabular}{cccccc}
\hline \multirow{2}{*}{ Tratamento } & \multicolumn{5}{c}{ Profundidade $(\mathrm{cm})$} \\
& $0-10$ & $10-20$ & $20-30$ & $30-60$ & $60-90$ \\
\hline C & $3,9 \mathrm{c}^{(1)}$ & $4,0 \mathrm{~b}$ & $4,1 \mathrm{~b}$ & $4,1 \mathrm{~b}$ & $4,2 \mathrm{~b}$ \\
$\mathrm{AM}$ & $3,8 \mathrm{c}$ & $4,0 \mathrm{~b}$ & $4,1 \mathrm{~b}$ & $4,1 \mathrm{~b}$ & $4,1 \mathrm{~b}$ \\
$10+\mathrm{K}$ & $4,2 \mathrm{bc}$ & $4,1 \mathrm{~b}$ & $4,1 \mathrm{~b}$ & $4,3 \mathrm{ab}$ & $4,3 \mathrm{ab}$ \\
$10+\mathrm{KP}$ & $4,2 \mathrm{bc}$ & $4,3 \mathrm{~b}$ & $4,1 \mathrm{~b}$ & $4,1 \mathrm{~b}$ & $4,2 \mathrm{~b}$ \\
$20+\mathrm{K}$ & $4,7 \mathrm{~b}$ & $4,4 \mathrm{~b}$ & $4,3 \mathrm{~b}$ & $4,2 \mathrm{~b}$ & $4,3 \mathrm{ab}$ \\
$40+\mathrm{K}$ & $6,0 \mathrm{a}$ & $5,3 \mathrm{a}$ & $5,0 \mathrm{a}$ & $4,5 \mathrm{a}$ & $4,7 \mathrm{a}$ \\
C.V. \% & 7,4 & 6,0 & 2,6 & 3,4 & 4,7 \\
\hline (1) & \multicolumn{5}{c}{}
\end{tabular}

APÊNDICE 2 - Teor de carbono orgânico $\left(\mathrm{g} \mathrm{dm}^{-3}\right)$. Resultados expressos como média dos quatro blocos avaliados

\begin{tabular}{cccccc}
\hline \multirow{2}{*}{ Tratamento } & \multicolumn{5}{c}{ Profundidade (cm) } \\
& $0-10$ & $10-20$ & $20-30$ & $30-60$ & $60-90$ \\
\hline C & $15,6 \mathrm{a}^{(1)}$ & $9,0 \mathrm{a}$ & $8,1 \mathrm{a}$ & $5,4 \mathrm{~b}$ & $4,9 \mathrm{a}$ \\
AM & $15,3 \mathrm{a}$ & $7,7 \mathrm{a}$ & $7,7 \mathrm{a}$ & $6,7 \mathrm{a}$ & $4,9 \mathrm{a}$ \\
$10+\mathrm{K}$ & $17,2 \mathrm{a}$ & $8,9 \mathrm{a}$ & $9,0 \mathrm{a}$ & $6,2 \mathrm{ab}$ & $5,2 \mathrm{a}$ \\
$10+\mathrm{KP}$ & $17,3 \mathrm{a}$ & $11,2 \mathrm{a}$ & $8,0 \mathrm{a}$ & $6,1 \mathrm{ab}$ & $5,7 \mathrm{a}$ \\
$20+\mathrm{K}$ & $15,4 \mathrm{a}$ & $10,2 \mathrm{a}$ & $7,7 \mathrm{a}$ & $6,4 \mathrm{ab}$ & $5,2 \mathrm{a}$ \\
$40+\mathrm{K}$ & $15,9 \mathrm{a}$ & $10,5 \mathrm{a}$ & $7,6 \mathrm{a}$ & $5,8 \mathrm{ab}$ & $6,5 \mathrm{a}$ \\
C.V. \% & 28,15 & 22,03 & 17,00 & 8,22 & 32,48 \\
\hline
\end{tabular}

(1) médias seguidas da mesma letra, na coluna, não diferem entre si pelo teste de Tukey (nível 5\% de significância)

APÊNDICE 3 - Teor de $\mathrm{K}\left(\mathrm{mmol}_{\mathrm{c}} \mathrm{dm}^{-3}\right)$. Resultados expressos como média dos quatro blocos avaliados expresso como média dos quatro blocos avaliados

\begin{tabular}{cccccc}
\hline Tratamento & & \multicolumn{5}{c}{ Profundidade $(\mathrm{cm})$} \\
& $0-10$ & $10-20$ & $20-30$ & $30-60$ & $60-90$ \\
\hline C & $0,3 \mathrm{a}$ & $0,2 \mathrm{a}$ & $0,1 \mathrm{a}$ & $0,1 \mathrm{a}$ & $0,1 \mathrm{a}$ \\
$10+\mathrm{K}$ & $0,4 \mathrm{a}$ & $0,1 \mathrm{a}$ & $0,2 \mathrm{a}$ & $0,1 \mathrm{a}$ & $0,1 \mathrm{a}$ \\
$10+\mathrm{KP}$ & $0,3 \mathrm{a}$ & $0,2 \mathrm{a}$ & $0,1 \mathrm{a}$ & $0,2 \mathrm{a}$ & $0,1 \mathrm{a}$ \\
$20+\mathrm{K}$ & $0,3 \mathrm{a}$ & $0,2 \mathrm{a}$ & $0,1 \mathrm{a}$ & $0,1 \mathrm{a}$ & $0,2 \mathrm{a}$ \\
$40+\mathrm{K}$ & $0,3 \mathrm{a}$ & $0,1 \mathrm{a}$ & $0,1 \mathrm{a}$ & $0,1 \mathrm{a}$ & $0,1 \mathrm{a}$ \\
C.V. \% & $0,3 \mathrm{a}$ & $0,2 \mathrm{a}$ & $0,1 \mathrm{a}$ & $0,1 \mathrm{a}$ & $0,1 \mathrm{a}$ \\
\hline
\end{tabular}

(1) médias seguidas da mesma letra, na coluna, não diferem entre si pelo teste de Tukey (nível 5\% de significância) 
APÊNDICE 4 - Teor de $\mathrm{Mg}\left(\mathrm{mmol}_{\mathrm{c}} \mathrm{dm}^{-3}\right)$. Resultados expressos como média dos quatro blocos avaliados expresso como média dos quatro blocos avaliados

\begin{tabular}{cccccc}
\hline \multirow{2}{*}{ Tratamento } & \multicolumn{5}{c}{ Profundidade (cm) } \\
\hline C & $0-10$ & $10-20$ & $20-30$ & $30-60$ & $60-90$ \\
AM & $2,0 \mathrm{a}(1)$ & $2,0 \mathrm{a}$ & $2,0 \mathrm{a}$ & $1,8 \mathrm{a}$ & $2,0 \mathrm{a}$ \\
$10+\mathrm{K}$ & $2,0 \mathrm{a}$ & $2,0 \mathrm{a}$ & $2,0 \mathrm{a}$ & $1,8 \mathrm{a}$ & $1,8 \mathrm{a}$ \\
$10+\mathrm{KP}$ & $2,0 \mathrm{a}$ & $2,0 \mathrm{a}$ & $2,3 \mathrm{a}$ & $2,0 \mathrm{a}$ & $2,3 \mathrm{a}$ \\
$20+\mathrm{K}$ & $2,0 \mathrm{a}$ & $2,3 \mathrm{a}$ & $1,8 \mathrm{a}$ & $1,8 \mathrm{a}$ & $1,8 \mathrm{a}$ \\
$40+\mathrm{K}$ & $2,0 \mathrm{a}$ & $2,0 \mathrm{a}$ & $2,0 \mathrm{a}$ & $2,0 \mathrm{a}$ & $2,0 \mathrm{a}$ \\
C.V. \% & $2,3 \mathrm{a}$ & $2,0 \mathrm{a}$ & $2,0 \mathrm{a}$ & $2,0 \mathrm{a}$ & $2,0 \mathrm{a}$ \\
\hline (1) & 10,0 & 10,0 & 10,4 & 14,6 & 24,5 \\
\multicolumn{7}{l}{ (nédias seguidas da mesma letra, na coluna, não diferem entre si pelo teste de Tukey }
\end{tabular}

APÊNDICE 5 - Teor de P - resina $\left(\mathrm{mg} \mathrm{dm}^{-3}\right)$. Resultados expressos como média dos quatro blocos avaliados

\begin{tabular}{cccccc}
\hline \multirow{2}{*}{ Tratamento } & $0-10$ & $10-20$ & $20-30$ & $30-60$ & $60-90$ \\
\hline C & $3,0 \mathrm{~b}^{(1)}$ & $2,3 \mathrm{~b}$ & $2,5 \mathrm{a}$ & $1,0 \mathrm{a}$ & $1,0 \mathrm{~b}$ \\
$\mathrm{AM}$ & $2,3 \mathrm{~b}$ & $1,3 \mathrm{~b}$ & $1,8 \mathrm{a}$ & $1,0 \mathrm{a}$ & $1,0 \mathrm{~b}$ \\
$10+\mathrm{K}$ & $18,5 \mathrm{~b}$ & $8,3 \mathrm{ab}$ & $9,3 \mathrm{a}$ & $4,3 \mathrm{a}$ & $1,5 \mathrm{~b}$ \\
$10+\mathrm{KP}$ & $11,0 \mathrm{~b}$ & $14,3 \mathrm{ab}$ & $1,8 \mathrm{a}$ & $1,3 \mathrm{a}$ & $1,3 \mathrm{~b}$ \\
$20+\mathrm{K}$ & $22,0 \mathrm{~b}$ & $8,3 \mathrm{ab}$ & $6,8 \mathrm{a}$ & $1,8 \mathrm{a}$ & $1,0 \mathrm{~b}$ \\
$40+\mathrm{K}$ & $290,3 \mathrm{a}$ & $35,8 \mathrm{a}$ & $8,3 \mathrm{a}$ & $4,5 \mathrm{a}$ & $28,3 \mathrm{a}$ \\
C.V. \% & 115,6 & 124,3 & 143,9 & 111,2 & 203,7 \\
\hline (1) & médias seguidas da mesma letra, na coluna, não diferem entre si pelo teste de Tukey \\
\multicolumn{5}{c}{ (nível 5\% de significância) }
\end{tabular}

APÊNDICE 6 - Teor de $\mathrm{Ca}\left(\mathrm{mmol}_{\mathrm{c}} \mathrm{dm}^{-3}\right)$. Resultados expressos como média dos quatro blocos avaliados

\begin{tabular}{cccccc}
\hline \multirow{2}{*}{ Tratamento } & \multicolumn{5}{c}{ Profundidade $(\mathrm{cm})$} \\
\hline $\mathrm{C}$ & $0-10$ & $10-20$ & $20-30$ & $30-60$ & $60-90$ \\
$\mathrm{AM}$ & $1,8 \mathrm{c}^{(1)}$ & $2,3 \mathrm{~b}$ & $1,8 \mathrm{~b}$ & $2,3 \mathrm{~b}$ & $2,3 \mathrm{a}$ \\
$10+\mathrm{K}$ & $2,0 \mathrm{c}$ & $1,8 \mathrm{~b}$ & $2,0 \mathrm{~b}$ & $2,0 \mathrm{~b}$ & $2,0 \mathrm{a}$ \\
$10+\mathrm{KP}$ & $14,5 \mathrm{bc}$ & $7,0 \mathrm{~b}$ & $6,8 \mathrm{~b}$ & $6,0 \mathrm{ab}$ & $5,5 \mathrm{a}$ \\
$20+\mathrm{K}$ & $12,8 \mathrm{bc}$ & $12,8 \mathrm{ab}$ & $5,0 \mathrm{~b}$ & $2,8 \mathrm{~b}$ & $2,8 \mathrm{a}$ \\
$40+\mathrm{K}$ & $25,3 \mathrm{~b}$ & $9,8 \mathrm{ab}$ & $7,3 \mathrm{~b}$ & $5,3 \mathrm{ab}$ & $3,5 \mathrm{a}$ \\
C.V. \% & $52,3 \mathrm{a}$ & $25,5 \mathrm{a}$ & $19,3 \mathrm{a}$ & $9,8 \mathrm{a}$ & $13,0 \mathrm{a}$ \\
\hline (1) & 38,8 & 71,2 & 44,0 & 57,7 & 112,2 \\
\multicolumn{7}{l}{ (nédias seg 5\% de significância) }
\end{tabular}


APÊNDICE 7 - Teor de $\mathrm{H}+\mathrm{Al}\left(\mathrm{mmol}_{\mathrm{c}} \mathrm{dm}^{-3}\right)$. Resultados expressos como média dos quatro blocos avaliados

\begin{tabular}{clcccc}
\hline \multirow{2}{*}{ Tratamento } & \multicolumn{5}{c}{ Profundidade $(\mathrm{cm})$} \\
& $0-10$ & $10-20$ & $20-30$ & $30-60$ & $60-90$ \\
\hline C & $59,0 \mathrm{a}(1)$ & $43,5 \mathrm{a}$ & $45,5 \mathrm{a}$ & $31,0 \mathrm{a}$ & $25,8 \mathrm{ab}$ \\
$\mathrm{AM}$ & $75,3 \mathrm{a}$ & $42,3 \mathrm{a}$ & $43,8 \mathrm{a}$ & $34,8 \mathrm{a}$ & $27,8 \mathrm{ab}$ \\
$10+\mathrm{K}$ & $46,0 \mathrm{ab}$ & $41,5 \mathrm{ab}$ & $37,3 \mathrm{ab}$ & $25,5 \mathrm{a}$ & $25,5 \mathrm{ab}$ \\
$10+\mathrm{KP}$ & $55,0 \mathrm{ab}$ & $38,5 \mathrm{ab}$ & $39,8 \mathrm{a}$ & $33,8 \mathrm{a}$ & $30,0 \mathrm{a}$ \\
$20+\mathrm{K}$ & $40,5 \mathrm{ab}$ & $40,5 \mathrm{ab}$ & $34,8 \mathrm{ab}$ & $28,8 \mathrm{a}$ & $27,3 \mathrm{ab}$ \\
$40+\mathrm{K}$ & $14,0 \mathrm{~b}$ & $19,0 \mathrm{~b}$ & $20,5 \mathrm{~b}$ & $22,0 \mathrm{a}$ & $19,5 \mathrm{~b}$ \\
C.V. \% & 39,1 & 26,6 & 21,3 & 20,1 & 17,2 \\
\hline (1) & médias seguidas da mesma letra, na coluna, não diferem entre si pelo teste de Tukey \\
\multicolumn{4}{l}{ (nível 5\% de significância) }
\end{tabular}

APÊNDICE 8 - Teor de Al $\left(\mathrm{mmol}_{\mathrm{c}} \mathrm{dm}^{-3}\right)$. Resultados expressos como média dos quatro blocos avaliados expresso como média dos quatro blocos avaliados

\begin{tabular}{cccccc}
\hline \multirow{2}{*}{ Tratamento } & & \multicolumn{5}{c}{ Profundidade (cm) } \\
& $0-10$ & $10-20$ & $20-30$ & $30-60$ & $60-90$ \\
\hline C & $12,8 \mathrm{a}(1)$ & $10,0 \mathrm{a}$ & $9,0 \mathrm{a}$ & $8,0 \mathrm{a}$ & $6,5 \mathrm{a}$ \\
$\mathrm{AM}$ & $14,0 \mathrm{a}$ & $10,8 \mathrm{a}$ & $9,3 \mathrm{a}$ & $8,5 \mathrm{a}$ & $7,0 \mathrm{a}$ \\
$10+\mathrm{K}$ & $7,5 \mathrm{abc}$ & $8,0 \mathrm{a}$ & $7,5 \mathrm{a}$ & $6,0 \mathrm{ab}$ & $5,5 \mathrm{ab}$ \\
$10+\mathrm{KP}$ & $8,8 \mathrm{ab}$ & $7,5 \mathrm{a}$ & $8,3 \mathrm{a}$ & $7,8 \mathrm{a}$ & $6,5 \mathrm{a}$ \\
$20+\mathrm{K}$ & $5,0 \mathrm{bc}$ & $6,3 \mathrm{a}$ & $6,5 \mathrm{a}$ & $6,8 \mathrm{a}$ & $6,0 \mathrm{a}$ \\
$40+\mathrm{K}$ & $0,0 \mathrm{c}$ & $0,8 \mathrm{~b}$ & $1,8 \mathrm{~b}$ & $4,0 \mathrm{~b}$ & $2,8 \mathrm{~b}$ \\
C.V. $\%$ & 41,9 & 31,3 & 22,2 & 17,4 & 21,4 \\
\hline
\end{tabular}

(1) médias seguidas da mesma letra, na coluna, não diferem entre si pelo teste de Tukey (nível 5\% de significância)

APÊNDICE 9 - Condutividade elétrica (uS $\mathrm{dm}^{-3}$ ). Resultados expressos como média dos quatro blocos avaliados

\begin{tabular}{cccccc}
\hline \multirow{2}{*}{ Tratamento } & \multicolumn{5}{c}{ Profundidade $(\mathrm{cm})$} \\
& $0-10$ & $10-20$ & $20-30$ & $30-60$ & $60-90$ \\
\hline C & $126,85 \mathrm{~b}$ & $79,70 \mathrm{~b}$ & $78,13 \mathrm{a}$ & $52,38 \mathrm{c}$ & $58,08 \mathrm{a}$ \\
AM & $127,38 \mathrm{~b}$ & $356,60 \mathrm{~b}$ & $80,60 \mathrm{a}$ & $56,55 \mathrm{bc}$ & $35,60 \mathrm{a}$ \\
$10+\mathrm{K}$ & $126,88 \mathrm{~b}$ & $105,70 \mathrm{~b}$ & $83,28 \mathrm{a}$ & $94,83 \mathrm{ab}$ & $45,05 \mathrm{a}$ \\
$10+\mathrm{KP}$ & $132,43 \mathrm{~b}$ & $122,68 \mathrm{~b}$ & $84,80 \mathrm{a}$ & $60,55 \mathrm{bc}$ & $33,10 \mathrm{a}$ \\
$20+\mathrm{K}$ & $161,75 \mathrm{~b}$ & $103,25 \mathrm{~b}$ & $99,48 \mathrm{a}$ & $66,78 \mathrm{abc}$ & $52,65 \mathrm{a}$ \\
$40+\mathrm{K}$ & $321,25 \mathrm{a}$ & $236,35 \mathrm{a}$ & $157,03 \mathrm{a}$ & $103,65 \mathrm{a}$ & $129,90 \mathrm{a}$ \\
C.V. \% & 31,31 & 34,48 & 50,11 & 23,31 & 86,30 \\
\hline (1) & \multicolumn{5}{l}{}
\end{tabular}

